\title{
Creedal Controversies among Armenians in the Seventeenth-Century Ottoman Empire
}

Eremia Č'èlèpi K'èōmiwrčean's Polemical Writing against Suk'ias Prusac'i

\author{
Anna Ohanjanyan \\ Mashtots Institute of Ancient Manuscripts "Matenadaran," \\ Yerevan, Armenia \\ annaohanjanyan@gmail.com
}

\begin{abstract}
In the late seventeenth century along the lines of European confession-building and Ottoman sunnitization, the Armenian Apostolic Church initiated the reshaping of its orthodoxy in the face of growing Tridentine Catholicism. Through the contextualization of the polemical writing attributed to the famed Constantinopolitan Armenian erudite Eremia Č'ēlēpi K'ēōmiwrčean, this article discusses the ways of detecting "bad innovations" in the doctrine and practice of Armenian communities in the Ottoman realms, and the doctrinal instruments used for enforcing "pure faith" towards social disciplining of the Apostolic Armenians.
\end{abstract}

\section{Keywords}

Eremia Č'ēlēpi K'ēōmiwrčean - anathema - Armenian Church - Armenian Theology - Roman Catholic and Armenian Church relations - Tridentine Catholicism bad innovation - confessionalization - catechism - 'ilm-i hāl - Nicene Creed orthopraxy - polemics - sunnitization 
In the age of "mutually exclusive and restrictive infallible churchdoms" as Ernst Troeltsch claims, the seventeenth-century Constantinople-based Armenian author Eremia Č́ēēēpi K'ēōmiwrčean (1637-1695) stood as "a man who rescued his century." Eremia's extensive historiographic heritage has not only documented the socio-historical sweep of the Armenian communal life in the Ottoman Empire, but has also represented the Armenian viewpoint regarding major religious and political developments across the Empire and, in particular, within the Empire's Armenian communities.

Ute Lotz-Heumann argues that early modern confession-building processes noticeably affected literary genres, works, and their authors across Europe and beyond its boundaries. ${ }^{3}$ Such an impact made polemical, catechetical, liturgical and spiritual writings from the period extremely valuable for better understanding the entangled social processes of the premodern world. In this regard, Eremia Č'èlēpi's polemical writings are considered as important as his historical oeuvre. Largely recognized as a historiographer, Eremia Č́ēlēpi has not been recognized as either a polemicist or a catechist. His polemical treatises, however, contain rich material for the study of the confession-building dynamics within the Armenian communities in the early modern Ottoman society.

This article seeks to explore Eremia K'ēōmiwrčean's polemical writing against Suk'ias, the Armenian prelate of Bursa. Through the polemical encounter of these two men, this article seeks to disclose creedal controversies among the Armenian communities in the Ottoman Empire in the confessional age. The article attempts to reconstruct Suk'ias's life and relations with Eremia K'ēōmiwrčean as well as the politico-confessional context in the scope of which their debate transpired.

1 I am grateful to Tijana Krstić and Sebouh David Aslanian for their helpful suggestions on this article. This project has received funding from the European Research Council (ERC) under the European Union's Horizon 2020 research and innovation programme (grant agreement No 648498).

2 Ernst Troeltsch, "Die Bedeutung des Protestantismus für die Entstehung der Modernen Welt," Historische Zeitschrift 97, no. 1 (1906): 29. For a critical edition on Eremia Č'ēlēpi K'ēōmiwrčean, see Gayane Ayvazyan, "Eremia Ch'elepi K'yomyurchyani patmakan žarangut'yuně" [The Historical Heritage of Eremia Č'ēlēpi K'ēōmiwrčean], (PhD diss., Institute of History, NASRA, 2014). For a complete bibliography of Eremia's works, see Gayane Ayvazyan, "Eremia K'yomurchyani dzeragrakan zhaṛangut'yuně" [The Manuscript Heritage of Eremia K'ēōmiwrčean], Banber Matenadarani 2o, (2014): 349-398. Yakob Siruni, Pōlis ev ir derě [Constantinople and its Role], vol. 1, (Beirut: Mesrop Press, 1965), 606.

3 Ute Lotz-Heumann, Matthias Pohlig, "Confessionalization and Literature in the Empire, 1555-1700," Central European History 40, no. 1, (2007): 35-61. 


\section{Armenian Confession-Building within a Multi-Confessional Ottoman Framework}

The paradigm of confessionalization or confession-building (Konfessionsbildung) was put forward by German historian Ernst Walter Zeeden in search for common models of confessional, social, political development and the means of promoting the confessional identity during the period of the rise of Reformation and Counter Reformation. ${ }^{4}$ Zeeden's views were developed by Wolfgang Reinhard and Heinz Schilling in the early 198 os. $^{5}$ They argued that the building of the Lutheran, Catholic, and Reformed confessions in the sixteenth and seventeenth centuries had deeper social and political implications beyond theology, including the processes of early modern state building. Although Reinhard's and Schilling's theories have been vociferously criticized and modified since their formulation, the confessionalization paradigm "still addresses discord, disagreement and plurality within and between the various confessional spheres," hence, remains ongoing. ${ }^{6}$

In recent years scholars of the Ottoman Empire have begun to embrace paradigm's heuristic potential for understanding intra- and inter-communal dynamics among Ottoman Christians and Muslims. Tijana Kritić and Derin Terzioğlu studied a parallel process to confessionalization in the Ottoman Empire by coining it "sunnitization."7 The process of "sunnitization" aimed at Sunni identity formation and the reshaping of Sunni orthodoxy through indoctrination of the Muslim population in the face of both Safavid Shi'i challenge and the polyphony of Sunni practice. Interestingly, the Ottoman Christians as well experienced the impact of the confessional trends of the age. A multitude of patterns of confession-building processes in Greek, Slavic and Syriac

4 Ernst Walter Zeeden, Konfessionsbildung: Studien zur Reformation, Gegenreformation und katholischen Reform, (Stuttgart: Klett-Cotta, 1985).

5 Wolfgang Reinhard, "Reformation, Counter-Reformation, and the Early Modern State. A Reassessment," Catholic Historical Review 75, no. 3 (July 1989): 383-404. Heinz Schilling, "Confessionalization: Historical and Scholarly Perspective of a Comparative and Interdisciplinary Paradigm," in Confessionalization in Europe, 1550-170o, ed. John M. Headley, et. al. (Aldershot: Ashgate, 2004), 21-36.

6 For a summary of critical works, see Ute Lotz-Heuman, "The Concept of 'Confessionalization:' a Historiographical Paradigm in Dispute," Memoria y Civilización 4 (2001): 93-114; and "Forum" German History 32, no. 4 (2014): 579-598. See the discussion in "Forum," German History, 586.

7 On the processes of Sunnitization, and recent engagement with Sunnitization in the Ottoman context, both Muslim and Christian, see Tijana Krstić, Contested Conversions to Islam: Narratives of Religious Change in the Early Modern Ottoman Empire (Stanford, CA: Stanford University Press, 2011); Derin Terzioğlu, "How to Conceptualize Ottoman Sunnitization: A Historiographical Discussion," Turcica 44 (2012-13): 301-38. 
Christian Churches, reveals an important case of entangled histories in the early modern era. ${ }^{8}$

One should exercise caution when engaging with the theory of confessionalization as formulated by Reinhard and Schilling and its implications for the Armenian communities living in very different conditions in the Ottoman and Safavid realms. One can speak of the processes of confession-building or re-articulation of doctrine and practice, especially among the Armenian communities in the Ottoman Empire. However, Armenians never underwent confessional processes like Europe, particularly with the emergence of Protestantism in the sixteenth century. Armenian confessional developments fail to fit in the timeline of the confessional age-the late 1540s-1700 and 1520s-1731/32, as suggested by Reinhard and Schilling. ${ }^{9}$ Before the schism in the Armenian community of Lvov $\left(1625^{-1630}\right)$, relatively peaceful cohabitation with Tridentine missionaries prevailed in both Ottoman and Safavid parts of Armenia. As demonstrated by John Flennery and Christian Windler, the relationship between the Armenian clergy and missionary orders in Safavid Persia perfectly fit in the frames of "good correspondence."10 The vector of Armenian confession-building was internal rather than external, directed against the "inner confessional enemy" - the Catholic Armenians. The confessional consciousness of Armenian Apostolic clergy was triggered in the face of conversions to Catholicism. ${ }^{11}$ Therefore, it seems that confession-building processes in Armenian communities began in the early seventeenth century and lasted till the second half of the eighteenth century. Given that the Armenian Apostolic Church strove to reaffirm and reshape its miaphysite (or nonChalcedonic) faith through the preservation of traditions rather than to build

8 For recent scholarship, see Ovidiu Olar, "Io se puotesse reformare la mia chiesa, lo farei molto volentieri...' Kyrillos Loukaris and the Confessionalization of the Orthodox Church (1620-1638); John-Paul Ghobrial, "The Conversion to Catholicism of the Christians of Mosul in the Seventeenth century," papers presented at Entangled Confessionalizations? Dialogic Perspectives on Community and Confession-Building Initiatives in the Ottoman Empire, 15th-18th Centuries," Budapest, June 1-3, 2018 (Gorgias Press, 2020, forthcoming).

9 Lotz-Heuman, "The Concept," 101-102.

10 Christian Windler, "Ambiguous Belonging: How Catholic Missionaries in Persia and the Roman Curia dealt with Communicatio in Sacris," in A Companion to Early Modern Catholic Global Missions, ed. Ronnie Po-Chia Hsia (Leiden-Boston: Brill, 2018), 205-234; John Flannery, The Mission of the Portuguese Augustinians to Persia and Beyond (16021747), (Leiden: Brill, 2013), 111-147.

11 The term "Apostolic" has come into regular use in later centuries. For this period Lusaworčadawan from the insiders' perspective and Gregorian from the outsiders' perspective was a common use. However, here I circulate "Apostolic" to distinguish between miaphysite and Catholic Armenians. 
a new confession, the term "soft confessionalization" may be more suitable for the Armenian context. The same term is applicable to the sui juris Armenian Catholic Church, which, like the Chaldean Syrian Church, accommodated ancient Armenian Apostolic traditions with some exceptions in doctrine and practice, such as mixed chalice in the Communion and the doctrine of Filioque (i.e. the doctrine of procession of the Holy Spirit also from the Son). ${ }^{12}$

The mechanisms of European confessionalization contributed to the sunnitization processes in the Ottoman Empire, and included the following: the (re)formulation of "pure faith" through creeds and confessions of faith; the distribution of "pure faith"; and its enforcement and internalization towards social disciplining. Among other instruments of internalization-such as the installment of the namazcı office and empowerment of mosque preachersthe İlm-i häl ("state of faith") literature, that is the Islamic equivalent of Catholic catechisms and Protestant pater familias literature, composed in the vernacular, became instrumental for training all Muslims in the vein of "correct Sunni faith and conduct."13 In constant contact and dialogue with both Western Christian and Muslim communities, Eastern Christians too, increasingly paid more attention to various formulas and definitions of faith and strove to define the limits of orthodoxy. In an attempt to redefine and enforce the "pure faith," the Armenian Apostolic Church gravitated toward appropriation of confessionalization mechanisms by resorting to the confessions of faith, creeds and catechisms. ${ }^{14}$ In this regard, Eremia K'ēōmiwrčean's polemics with Suk'ias Prusac'i shines light on the employment of confessional literature for social disciplining of the Armenian communities in the Ottoman lands.

12 More on the doctrine of Filioque, see A. Edward Siecienski, The Filioque: History of a Doctrinal Controversy (Oxford: Oxford University Press, 2010).

13 On the use of catechisms by Sunni Muslims, see Derin Terzioğlu, "Where İlm-i Hāal Meets Catechism: Islamic Manuals of Religious Instruction in the Ottoman Empire in the Age of Confessionalization," Past and Present 220, no. 1 (2013): 79-114; Tijana Krstić, "From Shahāda to 'Aqìda: Confession to Islam, Catechization and Sunnitization in Sixteenth-century Ottoman Rumeli," in Islamisation: Comparative Perspectives from History, ed. A.C.S. Peacock, (Edinburgh: University Press, 2017), 296-314.

14 For a more elaborate discussion on confessionalization for the early modern Armenian world, see Sebouh D. Aslanian, Early Modernity and Mobility: Port Cities and Printers Across the Armenian Diaspora, 1512-1800, chap. 3 (Yale University Press, forthcoming). I thank the author for kindly sharing the manuscript of the book with me. 
Eremia Č'èlēpi was born to a wealthy and renowned priestly family in Constantinople who contributed to the city's most significant developments. Well-educated and ambitious, he had never wished for a career as a cleric. His father Martiros K'ēōmiwrčean was the priest of Saint Sargis Armenian Apostolic Church of Langa. In 1652, during his visit to the city, Catholicos P'ilipos Ałbakec'i (1633-1655) appointed Martiros his vekil ("deputy") and treasurer of the alms-box of Ejmiats'in in Constantinople. Years later, Eremia would assume this obligation unofficially replacing Mahtesi AmbakumEremia's uncle on his mother's side, a descendent of a royal family, to whom the Catholicos had entrusted the alms-box after Martiros's death. Holding the offices of patriarchal secretary and counselor, and active in the high society of Constantinople, Eremia Č'ēlēpi fully integrated into the ecclesiastical, administrative, and economic life of the Armenian communities of the Empire. Running a bakery shop in the city market, where he spent most of his time, Eremia acted as an observer or t'emasha ("city-watcher"), which enhanced his knowledge of the social fabric of the city..$^{15}$ Eremia took his first steps as a historiographer when he was still twelve years of age. His Oragrut'iwn or Diary, illustrates the intra-, inter- and trans-communal history of the Ottoman Empire. In 1939, Mesrop Nshanian published the Diary along with some of his epistles, hymns, and laments. His Jewish Poems, containing polemical remarks about the followers of Šabbetay Sevi, have been published and partly translated as well.16 His major polemical writings against the Jews, Greeks, Armenian Catholics, and crypto-Protestants have heretofore remained unstudied.

Notwithstanding his early literary achievements as a historiographer, Eremia Čè̄ēêpi first voiced his objections against confessional "others" only in 1656 when he engaged himself in polemics with the Greeks in reaction to the rivalry over disputed sacred sites in the Holy Land. The Greeks in Jerusalem had been in fierce dispute with the Armenians since their deviation on the

15 The intense engagement of Armenians in urban life through city-watching people watching, promenading and exchanging information in maydans was an inseparable part of daily life for an average inhabitant of Constantinople. See Polina Ivanova, "Armenians in Urban Order and Disorder of Seventeenth-Century Istanbul," Journal of the Ottoman and Turkish Studies Association 4, no. 2 (2017): 239-26o.

16 Paolo Lucca, "Šabbetay Șewi and the Messianic Temptations of Ottoman Jews in the Seventeenth Century According to Christian Armenian Sources," in Contacts and Controversies between Muslims, Jews and Christians in the Ottoman Empire and Pre-Modern Iran, ed. Camilla Adang and Sabine Schmidtke (Würzburg: Ergon-Verlag, 2010), 197-206. 
date of Easter, referred to as crazatik ("curved Easter"). ${ }^{17}$ At that time the confessional quarrels over the "curved Easter" reached their climax, giving rise to a number of anecdotes among the Armenians and Greeks. ${ }^{18}$ In fact, the litigations between the Greeks and Armenians were for the domination over the sites of the Copts, Ethiopians, and Syriac Orthodox in Jerusalem, which were under the jurisdiction of the Armenian Church. Years later, in 1656, with the help of their Constantinopolitan allies, the Greeks succeeded in obtaining a permission from grand vizier Boynuyaralı Mehmed Pasha for the appropriation of an Ethiopian church of Abba Abraham that used to be under Armenian jurisdiction.

The Armenian Patriarch of Jerusalem Astuacatur Taronc'i (1645-1664; 1668 1670) arrived in Constantinople to seek the assistance of wealthy Armenians in settling the issue. Being aware of the wealth and influential role of vardapet Eliazar Aynt'apec'i, the patriarch promised the position of vekilin return for his support. Given that Eliazar had found himself in the middle of a severe competition for the patriarch's office in Constantinople with the deposed patriarch Yovhannēs Mułnec'i (1652-1655), he agreed to negotiate with Boynuyaralı Mehmed Pasha to return the Ethiopian Church to the Armenians. ${ }^{19}$ Etiazar succeeded in his effort with the help of Xoja Riuhijan, a wealthy Armenian with excellent connections to the Ottoman elite. As promised, he was appointed the patriarchal vekil in Jerusalem, where he headed at the beginning of October, 1656. When Köprülü Mehmed Pasha (1656-1661) assumed the office of grand vizier, Patriarch Paiseus of Jerusalem (1645-166o) negotiated on behalf of the Greeks to obtain a firman, allowing the Greek Church to usurp not only the

17 For more details on the deviation of the date of Easter, see Pavel Kuzenkov, "Corrections of the Easter Computus: Heresy or Necessity? Fourteenth Century Byzantine Forerunners of the Gregorian Reform," in Orthodoxy and Heresy in Byzantium: The Definition and the Notion of Orthodoxy and Some Other Studies on the Heresies and the Non-Christian Religions, ed. Antonio Rigo, Pavel Ermilov (Roma: Università degli Studi di Roma "Tor Vergata," 2010), 147-158.

18 For Greek sources about these events, see Pavel Kuzenkov, Konstantin Panchenko, “'Krivye Paskhi i Blagodatniy Ogon' v Istoricheskoy Retrospektive" [“'Curved Easters and the Holy Fire' in the Historical Retrospective"], Vestnik Moskovskogo Universiteta 13, no. 4, (2006): 3-29. It seems that Dositheos II of Jerusalem and later historiographers have simply seconded the famous narrative about the Ascent of the Holy Fire, circulating in the early modern Orthodox folklore.

19 The real intention of Ełiazar was to diminish the influence of Ejmiacin over the Armenians under Ottoman jurisdiction. Therefore, the newly elected Catholicos Yakob $J^{\vee} u ł a y e c ' i\left(1655^{-1680}\right)$ took the side of Yovhannēs Mułnec'i. For this reason, the monks in Constantinople refused to mention Yakob J’ułayec'i's name during the Divine Liturgy for some time. Eremia Č'ēelēpi K'ēōmiwrčean, Ōragrut'iwn [Diary], ed. Mesrop Nshanian, (Jerusalem: St. James Press, 1939), 209. 
Ethiopian dominions in Jerusalem, but also the Armenian Convent of Saints James. ${ }^{20}$ Ełiazar Aynt'apec'i was accused of disobedience and persecuted during this process, escaping to Aleppo. Afterwards, he was further detained by the ruler of Damascus, Teyar Oğlu, then transferred to Bursa, from where he escaped but was apprehended again and brought to face Köprülü Mehmed Pasha. He was finally released thanks to the intervention of Xoǰa Rंuhijanan and Eremia K'ēōmiwrčean. It was not until 1659, through the mediation of Köprülü Mehmed Pasha's kahya ("chamberlain"), that Eliazar resumed the rights of the Armenians to the Saints James Convent. ${ }^{21}$

In light of the aforementioned events in 1656, Eremia Č'èlēpi composed his Vičabanut'iwn Yunac'. J'atagovut'iwn Haykakan Eketec'woy (Polemics with the Greeks or Vindication of the Armenian Church) known also as the Apology of the Rites of the Armenian Church - a work that has remained hitherto unpublished. ${ }^{22}$ We know little about Eremia's polemical treatise: he mentions once his piece "on the Greeks," but he might probably be referring to his Vipasanut'iwn Arman Surb Gēorg Eketec'woy (Narrative on the Takeover of Saint Gēorg Church from the Greeks) penned in $1677 .^{23}$

20 According to a well-known anecdote this convent was granted to the Armenians in Jerusalem by the prophet Muhammad. See Samuēl Anec'i, Hawak'munk' igroc' patmagrac [Compilation from the Writings of Historiographers], ed. Arshak Tēr-Mik'elian, (Vagharshapat: St. Ejmiatsin Press, 1893), 80; Mxit'ar Anec'i, Patmut'iwn [History], ed. Kerovbe Patkanian (Saint-Petersburg: 1879), 47; Babken Kiwleserian, Islamě hay matenagrutyan mej [Islam in Armenian Literature], (Vienna: Mekhitarist Press, 1930), 122.

21 For details, see K'ēōmiwrčean, Ōragrut'îwn, 206, 225-226, et. cetera. Mik'ael Č'amč‘ian describes these events based solely on Eremia's Diary and Chronicle [Taregrut'yiwn], see Mik'ael Č'amč'ian, Hayoc' patmut'iwn [History of Armenia], vol. 3, (Venice: St. Lazzaro, 1786), 671-687.

22 The manuscript is preserved in Mekhitarist Library of Venice, V621. For details see Ayvazyan, "Eremia K'yomurchyani," 362 . There is an uncatalogued polemical writing against the Jews (old cat. no. V1155), which is not to be confused with Eremia's Jewish Poems on Šabbateans. Henceforth Armenian manuscripts are cited according to Bernard Coulie's system in Répertoire des bibliothèques et des catalogues de manuscripts arméniens. Liste des utilisés pour désigner les manuscrits, (Accociation Internationale des Études Arméniennes, edition revue: 2002), https://sites.uclouvain.be/aiea/wp-content/uploads/2014/o3/Sigles.pdf

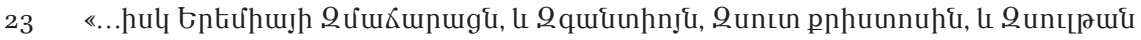

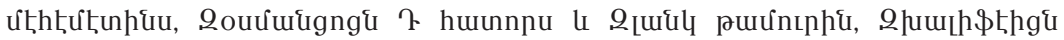

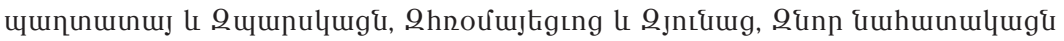

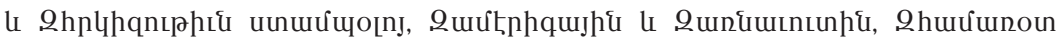

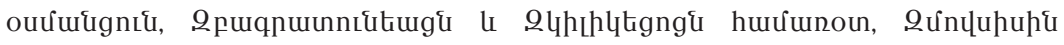

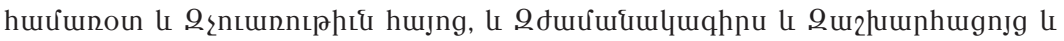

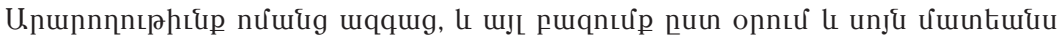
úuuiminnumbu...» (... and Eremia's on the Hungarians, and Crete, False Christ and 
Eremia Č'èlēpi's reproachful stance towards the Greek Orthodox Church was expressed early on, versus his balanced attitude towards the Roman Catholic Church-specifically Catholic Armenians. Eremia compiled an Armenian Catholic catechism in 1681, titled Girk' harc'manc' ("Book of Questions"). ${ }^{24}$ It was commissioned by an Armenian Catholic priest T'adēos Hamazaspean Isfahanc'i (Erevanc'i), who along with the Julfan Armenian merchant residing in Venice Xoja Gaspar Sarhadean, established a printing press in Venice and published a Xorhrdatetr ("Missal") and Čašoc' ("Lectionary") in $1686 .{ }^{25}$ T'adēos's confessional identity seems to be rather ambiguous; in 1691 the Roman Curia

Sultan Mehmed, four volumes on Ottomans and Tamerlane, Caliphate of Baghdad and Persians, on the Romans and Greeks, on New martyrs and the Fire of Istanbul, on America and Albanian [baker], Brief on Ottomans, on Bagratide dynasty and Brief on Cilicians [i.e. Rubenid and Hetumid dynasties], Brief on Moses, and the Flight of Armenians, on the Chroniclers and Geography and Traditions of some nations, and many other things and this codex in particular...), NOJ498, f.77r. Editio princeps published by Yarut'iwn K'iwrtian, "Vipasanut'iwn arman Surb Gēorg ekełec'woy, or i Makēdoniay i P'ilipupolis i jeracc azgin Yunac" [The Narrative on the Takeover of Saint Gevorg Church that is in Macedonia in Philippopolis from the Hands of the Greeks], Bazmavep 84, no. 8-9, (1927), 237-239. For the bibliographical details, see Ayvazyan, "Eremia K'yomurchyani," 354-355, 385-386, n. 454-457.

24 Eremia's Book of Questions is preserved in two copies: one in New Julfa (NOJ498), and an incomplete version at the Matenadaran (M72; f.123r-179v). Its full caption is $\left[\mathrm{H}^{\mathrm{arc}} \mathrm{aw}^{\mathrm{e}}\right.$ patasxank'usumnasirac'xndrotac', or uni ink'ean parunakeal imasanc'astuacabanut'eanc' ew p'ilisop'ayut'eanc' ew žamanakagrut'eanc' ew kerpic' atōt'ic'areal i latinac'woc', yunac' ew hayoc', [Question and Answers of the Seeker Philomaths, that Contain Excerpts from Theology and Philosophy and Chronicles and Kinds of Prayers Taken from Latins, Greeks and Armenians].

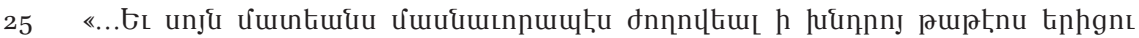

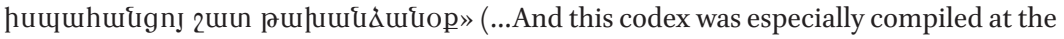
behest of the priest T'adēos Isfahanc'i with much solicitation), NOJ498, f.77r-v. For T'adēos Hamazaspean's autobiography, see [Grigor Galemk'erian], "T'adēi ericu patmakan mēk gorcě" [An Historical Writing of Priest T'adēos], Handēs Amsōreay 1, no. 11 (1887): 168-173, no 12: 194-197. For T'adēos's letter to Ełiazar Aynt'apec'i, see Čashoc' [Lectionary], (Venice: St. Lazzaro, 1686), 2-3. The fact that in Istanbul T'adēos Hamazaspean commissioned Eremia K'ēōmiwrčean to compile an Armenian-Catholic catechism as his pocketbook has remained hitherto unknown. However, Sahak Djemjemian talks about Hamazaspean's visit to Istanbul with Salomon de Leon, Oskan Eerevanc'i's nephew and fellow printer. For the details see his Hay tpagrut 'iwně ev Hrom. ZHE dar [Armenian Typography and Rome: XVII century], (Venice: St. Lazzaro, 1989), 151-155. Apart from the Missal and Lectionary in 1687, Xoǰa Gaspar and T'adēos published Xokumn K'ristonēakan [Christian Meditation] translated by Catholic Armenian author Yovhannēs Holov or Yakob Kostandnupolsets'i (1635-1691). Presumably, the print was carried out by Giacomo Moretti's printing house or was under its nominal jurisdiction, as the book has his name on the title page. After 1688 Gaspar quit the printing enterprise. For more details see Raymond H. Kévorkian, Catalogue des "incunables" arméniens (1511/1695) ou chronique de l'imprimerie arménienne. 
labeled the missal he printed in Venice as "heretical," because the text followed the Armenian Apostolic tradition. ${ }^{26}$ However, the Book of Questions that Eremia tailored for T'adēos might be considered the first Armenian-Catholic catechism per se. ${ }^{27}$ The very existence of such a catechism proves that-if solicited and probably commissioned-Eremia would have written equally for both the Apostolic and Catholic Armenians.

After 1691-when Eremia wrote against the Armenian Catholics and Lutherans-he explained the social causes of such tolerance towards Catholicism. ${ }^{28}$ Criticizing the wealthy youth of Constantinople as being keen on "prestigious European" confessions, Eremia claims:

bs qh untintlumgtime th $\mathrm{p}$ ingniug, qh qunpunug, ujuhipe

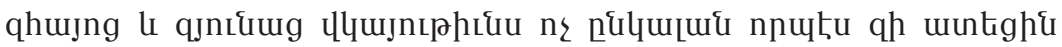

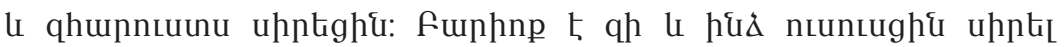
quitounntuu quhptihu hıptiuig

And as I have been informed of them [the wealthy], that they do not accept the attestations [of faith] of the poor, that is, of Armenians and Greeks, for they loathed [the latter] and loved the rich [Catholics and Protestants]. Fair enough, for I too was taught to love the wealthy—-their favorites [MS V317, f.1r]. ${ }^{29}$

It seems that in the past Eremia K'ēōmiwrčean somewhat tolerated proCatholic affinities among Armenians. It is important here to acknowledge that Eremia's attitude towards pro-Catholic Armenians changed after 1692, when

Préface de Jean-Pierre Mahé, (Geneve: P. Cramer, 1986), 106-107. I owe this information to Sebouh D. Aslanian.

26 Djemdjemian assumes that in the Missal printed around that time, T'adēos attempted to steer clear of deviations from the Apostolic tradition in spite of his being a Catholic. Eremia played not the last role in keeping the Missal in line with the Armenian Church tradition as we see him put his seal on a certificate in 1682 attesting that he was involved in making corrections with Hamazaspean on the Missal: Djemdjemian, Hay tpagrut'iwné, 154-155 and 173-179.

27 The first part of the Book of Questions is an excerpt from the Christian Doctrine published by Oskan Erevanc'i in Amsterdam in 1667 (imprimatur by Brieven van Theodorus Petraeus), which corresponded to the "needs of the Armenians" more than that of Belarmin's Dottrina Christiana. See Doctrina Christiana: Armenice, in Latinum versa (Amstelodami: Imp. auctoris, et typis Armeniorum, 1667).

28 Bernard Heyberger, "Le Catholicisme Tridentin au Levant (XVII - XVIII e siècles)," Mélanges de l'Ecole française de Rome. Italie et Méditerranée 101-102, no. 2, (1989): 902.

29 Unless otherwise indicated translations of these original texts are my own. 
he penned his two major vindications of Armenian Apostolic faith against the "Frankish" practice. What exactly provoked this kind of switch in his attitude?

After the death of his three children-Yovsēp' in 1680, Sołomē in 1690 and his elder son vardapet Grigor in 1692, of whom he had great expectationsEremia got isolated from the outer world by "sacrificing himself to the books." 30 This period coincided with the surge in the activity of Catholic Armenian priests educated in Collegium Urbanum (a college established in 1627 by de Propaganda Fide in Rome to train Catholic missionaries from the East), who continued to occupy offices in Armenian churches and enjoy the liberty of preaching Tridentine Catholicism from their pulpits. ${ }^{31}$ In a letter to his friend and mentor Ełiazar Aynt'apec'i, Eremia Č'èlēpi describes the heated intracommunal debates on orthodoxy and orthopraxy initiated by vardapet Sargis T'ok'at'ec'i or Sargis Šahētc'i Gasparean in 169o, who publicly differentiated the Armenians into "Catholics and schismatics, Frank and Armenian." ${ }^{32}$

It is widely known that the Catholic strategy of infiltration into Eastern and Oriental Christian Churches turned out to be very productive. The access of Catholic Armenian priests into the Armenian churches through communicatio in sacris (here: participation of the Catholics in liturgical practices and sacraments like baptism, marriages and funerals with the Armenian Apostolics), and their printing activities under the protectorate of Charles de Ferriol (16911711) — Luis XIV's Ambassador to Constantinople and the Levant — provide the context in which the work and life of Eremia K'ēōmiwrčean can be better understood. ${ }^{33}$ The relatively patient attitude of the Ottomans towards European

$30 \quad$ K'ēōmiwrčean, Ōragrut'iwn, 66 and Appendix, 578-579.

31 Tridentine Catholicism represents Catholic doctrine and practice, in the celebration of the mass, following the reforms of the Council of Trent (1545-1563). It was a reaction to and against Protestantism. After the Council of Trent its decrees became imposed on Catholics of all orders in an attempt to synchronize the faith.

32 Sargis was the bishop of Bethlehem from 1684-169o. Ordained a vardapet by Minas Hamt'ec'i, he traveled to Jerusalem. He was consecrated a bishop by Ełiazar Aynt'apec'i in 1676. For more details, see Grigor Galemk'erian, Kensagrut'iwnner erku hay patriark'neru ev tasn episkoposneru ev zhamanakin kat'oghikēayk' [Biographies of Two Armenian Patriarchs and Ten Bishops and the Catholics of the Time], (Vienna: Mekhitarist Press, 1915), 64-99; Eremia Č́ēlēpi K'ēōmiwrčean, Patmut'iwn Stampōlay [History of Istanbul], ed. Vahan Torgomian, (Vienna: Mekhitarist Press, 1913), 176.

33 Altough communicatio in sacris was generally prohibited by the Holy Office in 1729, it continued to be exercised under certain conditions even after the prohibition. For an overview, see Cesare Santus, Trasgressioni Necessarie. Communicatio in Sacris, Coesistenza e Conflitti tra le Comunità Cristiane Orientali (Levante e Impero Ottomano, XVII-XVIII secolo), (Rome: Bibliothèque des Écoles Françaises de Rome et d'Athènes, 2019), 309-376. Idem, "La communicatio in sacris con gli 'scismatici' orientali in età moderna" in Les Mélanges de l'École française de Rome, 2014, (https:// 
presence in the Empire had changed after the Venetian occupation of Chios between 1694-1695. The occupation resulted in the Sultan's Hatt-ı S Serif("edict") in May 1695, proscribing the proselytizing activity of Catholic missionaries. ${ }^{34}$ At the time of this historical backdrop, Eremia Č'elēpi decided to exercise his talent as a polemicist and compose two works between 1692-1695:

(a) J'atagovut'iwn Hayastaneayc'Eketec'woy (Apology of the Armenian Church) composed as a refutation of diverse accusations against the practice of the Armenian Church coming from various confessions, mainly from crypto-Catholic and crypto-Protestant contexts. ${ }^{35}$

(b) Patasxani Astucov ev vasn Astucoy, or Argileac' 'Zisk ork' asenn,' zor Asac'eal en i Verjn Hawatamk'in (Response with God's help and concerning God to the Person, who Disallowed the Recitation of "As for those who say" at the end of the (reed), a brief treatise aimed at defending the practice of the Armenian Church against "precarious novelties."36

Historian Gayane Ayvazyan considers the two writings as a single treatise, and places them under the Apology of the Armenian Church — despite the fact that Eremia's biographer Nersēs Akinian, followed by a historian of Constantinople Yakob Siruni, considered them separate texts. ${ }^{37}$ Presumably, the two works

journals.openedition.org/mefrim/179o\#tocto1n2); Mardiros Abagian, "La Questione della 'communicatio in sacris' nel secolo XVIII e la formazione del Patriarcato Armeno Cattolico" [The question of Communicatio in Sacris in the Eighteenth Century and the Formation of the Armenian Catholic Patriarchate], Bazmavep 139, no. 1-2 (1981): 129-184; 141, no. 1-4 (1983): 215-234; 146, no. 1-4 (1988): 155-174; 147, no. 1-4 (1989): 244-258; 148, no. 1-2 (199o): 146-162; no. 3-4 (199o): 413-419; 149, no. 1-2 (1990): 461-476; 15o, no. 1-4 (1992): 202-216; Guillaume Aral, Les Arméniens Catholiques: Étude historique, juridique et institutionnelle XVII $-X V I I I^{\mathrm{e}}$ siècle; suivi Les Mythes de la Christianistion de l'Arménie, (Nice: Les Édition de Nichéphore, 2017), 104-112. On the common practice with Apostolic Armenians in New Julfa in the seventeenth century, see Windler, "Ambiguous Belonging," 205-234.

34 According to the Hatt-ı Şerif, Catholics were perceived as "not only Agents of the Roman Pope, but Spies in [Ottoman] Empire," thereby, the engagement of Armenians, Greeks and Syriacs with any Frank was punishable by the law. See A. de la Motraye, Travels through Europe, Asia and into Part of Africa, vol. 1, (London, 1723), 159, and 393-394. For a thorough treatment of the subject, see Santus, Trasgressioni necessarie, 316-320, and 320-358.

35 Yakob Siruni places the Apology under the caption Responses to Those who Slander against Armenian Church; Siruni, Pōlis, 63o. I am thankful to Archbishop Boghos Levon Zekiyan for his assistance in getting access to this manuscript at the Library of Mekhitarist Congregation in Venice. I am currently working on preparing a critical edition of the Apology.

36 Yakob Siruni mentions the Franks under the caption Response with God's help and Concerning God. Siruni, Pōlis, 630.

Ayvazyan, "Eremia K'yomurchyani," 36o and 39o, n. 74. 
were written simultaneously or shortly after each other as they contain similar textual passages:

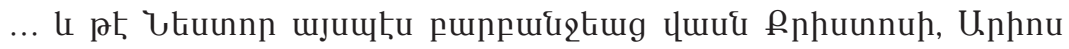

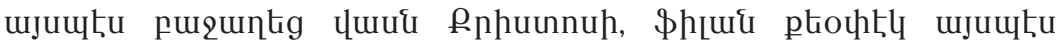

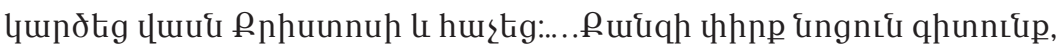

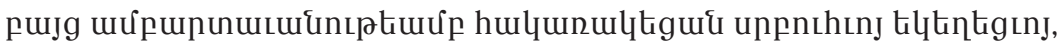

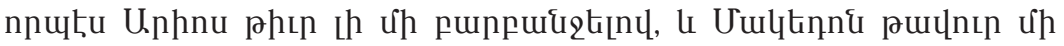

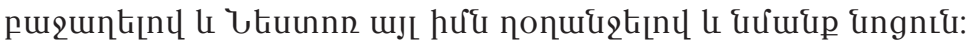

... and [telling] that Nestorius trifled in such-and-such manner about Christ, and Arius prattled so-and-so about Christ, and the such-and-such dog assumed so-and-so about Christ and barked [MS BNF Arm.334].... For their [Protestants] sages are knowledgeable, but they contradicted the Holy Church with haughtiness, likewise Arius trifling a lot of blunder and Macedon prattling something arrogant and Nestorius talking idly something else, and the likes of them [Ms V317].

Both writings reflect primarily on issues of orthopraxy within the Armenian Church. The Apology is the first document in Armenian officially testifying the existence of crypto-Protestant Armenians in Constantinople in the late seventeenth century. ${ }^{38}$ It is also a set of questions and answers on the "true faith" collected by Eremia from the representatives of various religious groups. In contrast, Response with God's help is a set of rhetorical questions and arguments, which Eremia himself addressed to Suk'ias, the prelate of Bursa, accusing him of planting "precarious" novelties into the minds of the Apostolic faithful. Suk'ias-Ełiazar Aynt'apec'i's desciple and loyal assistant—was advocating against the recital of the Nicene Anathema (incipit: "As for those who say") during the Divine Liturgy, which was the ancient custom of the Armenian Church. It provoked Eremia to rebuke Suk'ias for a "bad innovation" aimed at ruining the liturgical traditions and the reputation of the Apostolic Church.

38 It is worth noting that the scholarship on Protestants and Armenians has focused on the work of nineteenth-century missionaries, and this earlier phase is in need of further research. 
Little is known of Suk'ias (Hesychius, Gr. 'Hoúxlos), the Armenian prelate of Bursa, and his relations with Eremia K'ēōmiwrčean. ${ }^{39}$ Maghak'ia Ōrmanian refers to Suk'ias as to a prominent archpriest, whose name has remained unknown in history. ${ }^{40}$ To reconstruct his life, one has to delve into the small details scattered in manuscript colophons. The manuscript catalogues have preserved three vardapets by the name of Suk'ias who lived in the period in question, namely Suk'ias of Bursa (Prusac'i), Suk'ias of Van (Vanec'i) and Suk'ias of Tokat (T'ok'at'ec'i).

Careful examination of manuscripts demonstrates these three individuals to be the same person. Two arguments support this assumption. First is the poem dedicated to the Holy Virgin (incipit: Iskuhi Astuacacin, Surb Koys) preserved in the collection attributed to Suk'ias Vanec'i, which also appears under the name of Suk'ias Prusac'i, and Suk'ias T'ok'at'ec'i. ${ }^{41}$ Second, is the unique dating system used in the poems and colophons found under the name of either Suk'ias Prusac'i, Vanec'i or T'ok'at'ec'i. He writes the date, for instance,

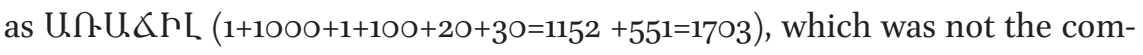
mon pattern of indicating a date according to the Armenian Era—otherwise

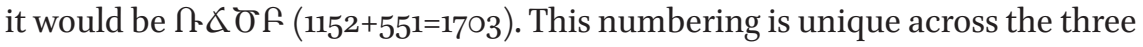
figures, and therefore this particular system supports the assumption that under all three names, the same Suk'ias is arguably to be recognized as the same scribe.

A theologian and a poet, vardapet Suk'ias was also a masterful scribe, commissioner, owner, donator and dedicatee of a multitude of manuscripts copied in Jerusalem, Bursa, Tigranakert and elsewhere affixed with his personal seal with the inscription "Suk'ias theologian vardapet." 42 In the colophon to a manuscript copied in 1674 in Jerusalem and sealed by Suk'ias, the latter calls himself T'ok'at'ec'i and mentions his father's and grandfather's names-Sargis

39 The copyist of a Girk' harc'otac' [Book of Questioners] (J619) reports in 1721 that he has copied it from the sample of Suk'ias, the archbishop of Bursa. In fact, Suk'ias is rarely called a bishop or an archbishop in the manuscripts, but rather "a theologian vardapet" or "a philosopher vardapet" that underlines him to be famous for his education and theological knowledge. Maghak'ia Ormanian, Azgapatum [Narratives of the Nation], vol. 2, (repr. Ejmiatsin, 2001), 3142 .

41 M1635, f. 7v-8r; M143o, f. 68r-69v; BNF Arm. 85, f. 170

42 For instance National Library of Armenians in Galata (ITT) 84, ITT 92, ITT 114; J623, J930, J940, J1741, J1587, J1926, J2827, J3202, J3328, Karmir vank' (ANKK) 124. 
and T'oros T'ok'at'ec'i, a proof that he came from Tokat (Eudokia). ${ }^{43}$ In most of the manuscripts he is called "theologian vardapet Suk'ias," whereas in his tats ("poems") and colophons he frequently refers to himself as "worthless and sinful Suk'ias." ${ }^{44}$ He was confusingly called Suk'ias Vanec'i because in two of his poems he mentions the city of Van in "Kurdistan" as the locus for some of his poems, which reveals him having spent some time in Eastern provinces of the Empire. The scribe of a Maštoc" ("Ritual Book") informs us that the nickname of Suk'ias Prusac'i was Karčahasak, meaning "of short height." Here his fame of being "a vardapet of vardapets" is also noted. ${ }^{45}$

Vardapet Suk'ias is said to have been born in 1636 . At the end of a poem which dates from 1702, he mentions that he is sixty-six years old. ${ }^{46} \mathrm{He}$ was Ełiazar Aynt'apec'i's student and protégé, who frequently accompanied him during his travels. In his Diary, Eremia remembers him as "vekil [deputy] of vardapet Ełiazar" only once while describing the trip to Galata and Balat in $1653 .{ }^{47} \mathrm{After}$ his release and dispatch to Jerusalem in 1659 - to assume the office of the Patriarch's vekil as well as to receive Saints James Convent back from the Greeks-Eliazar Aynt'apec'i conceived and carefully executed a plan to establish an anti-Catholicosate of Jerusalem. His aim was to detach the Armenian prelacies in Ottoman provinces from the pontifical seat of Ejmiacin, then under the control of his arch-rival, Catholicos of all Armenians Yakob IV $J^{`}$ ułayec'i $\left(1655^{-1680}\right) .{ }^{48}$ To this end, in 1663 Eliazar won the trust of Catholicos of Sis Xačatur Mintērči (1657-1674) to perform a service of consecration with holy myrrh by calling for the preservation of the Catholicosate of Cilicia. To justify his rivalry against Catholicos Yakob J`ułayec'i, Ełiazar had collected the

43 IтT 92, f. 742; see in Ts'uts'ak azgayin matenadaranin hayoc' $i$ Ghalat'ia, Kostandnupōlis [Catalogue of Manuscripts in Armenian National Library in Galata, Constantinople], ed. Babken Coadjutor Catholicos, (Lebanon: Antelias, 1961), 594.

Some of his poems were published in Ush mijnadari hay banasteghtsut'yuně (XVI-XVIIdd.) [The Armenian Poetry of Late Middle Ages (XVI-XviI Centuries)], ed. Hasmik Sahakyan, (Yerevan: Haykakan Gitut'yunneri Akademiayi Hratarakchut'yun, 1975), 392-443.

45 J2298, f. 326r; Mayr Ts'uts'ak dzeragrats' Srbots' Yakobeants'[Grand Catalogue of Manuscripts of Saints James Convent], ed. Norayr Pogharian, (Jerusalem: St. James Press, 1974), vol. 7, 492. See also, Bishop Tsovakan (= Norayr Pogharian), "Gavazanagirk' vardapetats" [List of Vardapets], Hask 22, no. 6-7 (1953): 171-172.

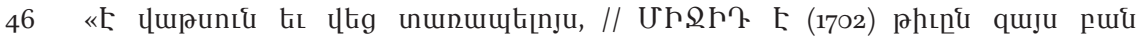
qnptinju...», M1635, f. 4ov.

47 K'ēōmiwrčean, Ōragrut'iwn, 47-48.

48 For the overview, see Avetis Sanjian, The Armenian Communities in Syria under Ottoman Dominion (Cambridge, MA: Harvard University Press, 1965), 104-109. See, Hakob Anasyan's seminal XVII dari azatagrakan sharzhumnerě Arevmtyan Hayastanum [Liberation Movements During the XVII Century in Western Armenia] (Yerevan: Haykakan Gitut'yunneri Akademiayi Hratarakchut'yun, 1961), 241-272. 
complaints about the vicious behavior of the Yakob J'ułayec'i's nviraks ("legates") in Ottoman lands. The legates started to sell the myrrh to the Western prelacies and provoked mistrust among the Armenians of the Empire. In 1664, with the efforts of Apro Č'ēlēpi-Eremia's relative and the banker (setanawor) of grand vizier Köprülüzade Fazıl Ahmed Pasha (1661-1676)—Ełiazar received the vizier's permission by having him assured that the detachment of Western prelacies from Ejmiacin in Persian lands would prevent the flow of Safavid spies to the Ottoman Empire. ${ }^{49}$

In 1664 Ełiazar Aynt'apec'i was consecrated by Xhač'atur Mintērči in Aleppo and became the Catholicos of Jerusalem. This evoked the wrath of Catholicos Yakob J`ułayec'i. ${ }^{50}$ Receiving the news from vardapet Martiros Kafac'i in 1665, he immediately summoned a council in Ejmiacin to launch a campaign against Ełiazar and sent encyclicals everywhere warning of Ełiazar's uncanonical course. ${ }^{51}$ As a consequence, Ełiazar had to roam around for a while, reaching Bursa, Edirne, and Constantinople while waiting for a firman from the grand vizier affirming his appointment as a Catholicos of Western Armenians and allowing him to take the throne of Jerusalem. Eventually, with bribery and the backing of Apro Č́èlēpi, he arrived in Jerusalem in 1667 as a "patriarch and Catholicos." 52 At the end of the same year, however, Catholicos Yakob J`ułayec'i's trustee Martiros Kafac'i armed with Sultan Mehmed IV's firman landed in Jerusalem and deposed Ełiazar for a short period. In 1670 Eliazar recovered his rights to the seat, again resorting to bribery. The copyist of a Tōnapatčar ("Festal Homiliary"), priest Sahak reports in his colophon that in 1677 once again Martiros Kafac'i and in 168 o Yovhannēs Amasiac'i Topal

49 Ōrmanian, Azgapatum, 2962-2965.

$50 \quad$ Örmanian, Azgapatum, 2965.

51 For Catholicos Yakob's encyclical letter, see Yarut'iwn K'iwrtian, "Yakob Kat'ołikos J`ułayec'ii noragiwt xist karevor vaverat'ught' mə" [Newly Discovered Extremely Important Document attributed to Catholicos Yakob J’ułayec'i], Sion 43, no. 3-4 (1969): 126-133. Another letter to Ełiazar from Eremia's father priest Martiros explicitly demonstrates the ardent willingness of the westerners to see Eliazar on the throne of Jerusalem as the Catholicos of the Western provinces. See "Martiros k'ahanay K'ēōmiwrčean K. Pōlsēn ar̉ Ełiazar Aynt'apc'i i Bera” [Priest Martiros K'ēōmiwrčean from Constantinople to Ełiazar Aynt'apc'i in Aleppo], Sion 6, no. 9 (1932): 278-28o.

$5^{2}$ When in 1667 Etiazar eventually settled in Jerusalem keeping the title catholicos, Apro went so far as to call him "the Catholicos of all Armenians"-a title reserved exceptionally for the Catholicos on the pontifical throne in Ejmiacin, see "Apro Č'êlēpi ar Ełiazar kat'ołikos" [Apro Č'ēlēpi to Catholicos Ełiazar], Sion 15, no. 1-2 (1941): 40. 
usurped the patriarchal throne of Jerusalem while Ełiazar "was silently sitting [somewhere] in Jerusalem."53

Ełiazar's loyal disciple vardapet Suk'ias was his patron's inseparable companion throughout his intriguing career. Suk'ias was by his side during the clashes between the Greeks and the Armenians in Jerusalem, $1656-1657 .{ }^{54}$ In 166o he was in Constantinople, in Üsküdar dispatched to settle fiscal issues on Ełiazar's behalf. Later in the same year he was in Jerusalem at his patron's feet. ${ }^{55}$ Suk'ias followed Ełiazar Aynt'apec'i all the way from Aleppo (1664-1667), where the latter was ordained a catholicos, up to his final settlement in Jerusalem in 1667.56 We do not know much about the Jerusalemian period of his life. Minas Hamt'ec'i's Ōragrut'iwn (Diary) may contain valuable information about the years spent in Jerusalem, but having its manuscript at hand, we have yet to examine it thoroughly. ${ }^{57}$ Piecing together various manuscript colophons, we do find Suk'ias in Jerusalem in 1668. In a manuscript colophon he claims to have found that manuscript in the city of Tigranakert. Years later he commissioned priest Tumas to copy it. Apparently, Suk'ias traveled to Tigranakert with his patron in 1652, where Etiazar used to be the prior of the monastery of the Barjrahayeac" Surb Astuacacin ("Exalted Mother of God"). ${ }^{58}$

In 1674-75, Suk'ias was in Jerusalem with Ełiazar, where he commissioned priest Eremia (known as a poet) to copy a collection of patristic works. ${ }^{59} \mathrm{In}$ 1677, when Martiros Kafac'i usurped the patriarchal throne in Jerusalem for the second time, Suk'ias was in Bursa, where he commissioned deacon Nikołayos to copy a collection of theological writings as a gift for Nahapet Edesac' $\mathrm{i}^{6}{ }^{60} \mathrm{In}$

$53 \mathrm{~J} 120, \mathrm{f}$ 919-921. See the colophon of the scribe Sahak in Tōnapatčar, Połarian, Mayr C'uc'ak, vol. 1, 336-337.

54 "Martiros vardapet Kafac'i Ṙotost'oyēn ar Ełiazar vardapet Aynt'apc'i yErusałēm" [Vartapet Martiros from Rodosto to Vardapet Ełiazar Aynt'apc'i in Jerusalem], Sion 4, no. 12 (1930): 384-385.

"Martiros Kafac'i patriark‘ K.Polsoy ar Ełiazar K. Polis" [Patriarch of Constantinople Martiros Kafac'i to Ełiazar in Constantinople], Sion 6, no. 8 (1932): 252.

56 We see Suk'ias in Aleppo attempting to dissuade Ełiazar from reading out the letter of ignominy sent by Martiros Kafac'i right after Ełiazar's consecration. See Ōrmanian, Azgapatum, 2972.

57 Mesrop Nshanian has selectively published passages relating to Eremia from Minas Hamt'ec'i's Öragrut'iwn (J1316) in his edition of Eremia's Diary. See K'ēomiwrčean, Ōragrut'iwn. Introducion, 136-144. Other brief passages might be found in, Połarian, Mayr C'uc'ak, vol. 4, 564-566.

$5^{8}$ ITT114, f. 91, see in Babken Catholicos, C'uc'ak, 297-299 and 728-73o.

59 Not to be confused with Eremia K'ēōmiwrčean. IтT84, f. 480, 591; Ітт92, f. 138, 206, 502, 742; Babken Catholicos, Ts'uts'ak, 560-562 and 593-594.

6o J82o, f. 551v, also Pogharian, Mayr C'uc'ak, vol. 3, 293. Later Minas Hamt'ec'i took this codex to Saints James Convent in Jerusalem. 
1680, Suk'ias was again in Jerusalem: his name appears in the list of the monks of Saints James, along with Nahapet Edesac'i, deacon Nersēs and many others. ${ }^{61}$ A number of manuscripts found in the library of Saints James Convent include his seal, suggesting that Suk'ias engaged himself in commissioning, copying and collecting the writings of church fathers and notable theologians, such as Philo of Alexandria, Basil of Caesarea, Gregory of Nisa, pseudo-Dionysius Areopagite and others. Suk'ias was respected by many famous clerics, such as Yovhannēs Mułnec'i, Martiros Kafac'i, Sargis T'ek'irtałec'i, who sent their respect and brotherly love to him through letters to Eliazar, while he was in Aleppo and Jerusalem. ${ }^{62}$ In the letters his name appears right next to Ełiazar's name proving him to be the eresp'oxan ("deputy") at Saints James Convent.

Suk'ias had a great deal of influence on his patron Ełiazar. In 1667 Apro Č́èlēpi wrote a secret letter to Suk'ias in Aleppo threatening to block allow the interference of the established peace, otherwise it "would not be good" for him, for "kurb-i sultan ateş-i suzan" ("being close to the sultan is being close to the fire")." ${ }^{63}$ Apparently, Apro alluded to the long awaited truce of 1667 between Martiros Kafac'i and Eliazar. The latter was invited to Constantinople or to Bursa - whichever city he preferred - to confirm and strengthen the reconciliation of the sides. ${ }^{64}$ According to the content of Apro's letter, Suk'ias was the one to persuade Eliazar to embark on this journey-further evidence of the influence Suk'ias had over his patron and power he possessed in the eyes of others.

When Catholicos Yakob J`ułayec'i passed away in 168o, the ecclesiastical council decided to invite Ełiazar to assume the pontifical throne in Ejmiacin, and thus to put an end to the schism of the Armenian Church. Eliazar accepted the offer, headed to Constantinople and from there to Ejmiacin in 1682. We find Suk'ias together with the chronicler Minas Hamt'ec'i (later Patriarch in Jerusalem), Nahapet Edesac'i (later Catholicos) and vardapet Nikołayos accompanying Ełiazar on his journey. ${ }^{65}$ As Minas Hamt'ec'i reports in his Diary, Suk'ias wandered about the monasteries of Eastern Armenia and went to view

61 For the entire list, see J12o, f. 919-921; Połarian, Mayr C'uc'ak, vol. 1, 336.

62 See various letters by the Armenian notables mentioning Suk'ias's name in Sion 4, no 12 (1930): 384; 6, no. 8 (1932): 254; no. 9 (1932): 280; 7, no. 1 (1933): 24; no. 4 (1933): 121; 14, no. 5-6 (1940): 156; 15, no. 1 (1941): 40; no. 3-4 (1941): 85, et cetera.

63 "Apron Suk'ias vardapetin xstut'eamb" [From Apro to vardapet Suk'ias with Austerity], Sion 15, no. 5 (1941): 126.

64 "Yovhan episkopos yAdrianupolsēn ar̉ Ełiazar episkopos i Halēp" [Bishop Yovhannēs from Edirne to bishop Ełiazar in Aleppo," Sion 15, no. 11-12 (1941): 308-310.

65 K'ēōmiwrčean, Ōragrut'iwn, Introduction, 99. See also, "Le Prétendu Masque de Fer Arménien ou Autobiographie du vardabied Avédik, de Thokhat, deposé du Patriarcat de Constantinople de de l'emploi de supérior de Jérusalem," Bulletin de l'Académie Impériale 
Sałmosavank. ${ }^{66}$ In 1689, two years before Catholicos Etiazar's death, Suk'ias was in the city of Van, where he suffered persecution by the nobles of "the foreign land" of Kurdistan and a six-month-long detention. Apparently, he fell victim to a hoax for the debts that he was ignorant of and was bailed out after he payed to vardapets Məxik and Margar. ${ }^{67}$ This might contradict the rumor spread in Ereamia's times that Suk'ias was at Ełiazar's deathbed in August, 1691. In his piece against Suk'ias, Eremia reproaches him for spreading deceitful rumors, that he was near Catholicos Etiazar while the latter was at his last breath, at which time he received instructions on doctrinal and disciplinary matters. Eremia was certain that Suk'ias was not in Ejmiacin when the Catholicos passed away. His opinion was based on the testimonies of his elder son, vardapet Grigor, who was pursuing his education in Ejmiacin, under the guidance of the Catholicos. Grigor received the news of Eliazar's passing while traveling to Constantinople early in August, hence he had no solid proof of Suk'ias's deception.

The date of Suk'ias's consecration as bishop and prelate of Bursa has not been established. Most probably it was after 1682. What we know for certain is that he was already holding this office from 1691-1695, when Eremia composed polemical writing against him. He was the very archbishop of Bursa who buried the body of a neo-martyr named Nikołayos Prusac'i, executed by the Ottomans in 1694 upon the sham accusation of apostasy. ${ }^{68}$ Importantly, in the martyrology of Nikołayos, Suk'ias acts as the impresario of the martyr-to-be. $\mathrm{He}$ is the one who sent off a certain priest to jail to encourage Nikołayos to take the "crown of martyrdom." 69

When exactly Suk'ias Prusac'i had grown into a pro-Catholic agent is murky. He was still the prelate of Bursa in 1704, when Eremia's brother Komitas

des Sciences de St.-Pétersbourg, ed. Marie-Félicité Brosset, 20 (Saint-Petersbourg: Imprimerie de l'Académie Impériale de sciences, 1875): 5 .

66 Manuscript in the Library of Saints James Convent, J1316, f. 21 .

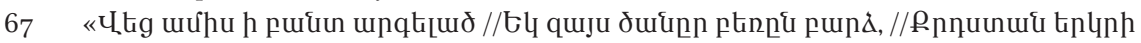

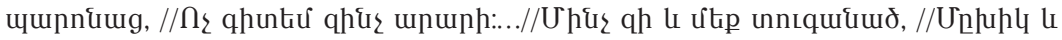

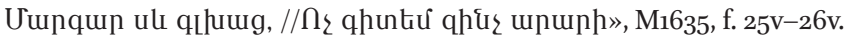

68 Hayots'norvkanerě (1155-1843) [Armenian Neo-Martyrs (1155-1843)], ed. Hrachya Achaṛan and Hakob Manandyan, (Vagharshapat: St. Ejmiatsin Press, 1903), 532-534.

69 Ačaryan, Hayots' nor vkanerě, 533. For more on impresarios, see Krstić, Contested Conversions, 121-132. Another testimony about Suk'ias being the bishop of the city is the colophon dated to 1695; ANKK 124, f. 546; see in C'uc'ak jeragrac' Ankiwroy Karmir Vanuc' ev šrjakayic' [Catalogue of the Manuscripts of Monastery Karmir Vank in Ankyra and its Neighboring Monasteries], ed. Babken Coadjutor Catholicos, (Lebanon: Antelias, 1957), 617 . 
$\mathrm{K}^{‘}$ ēōmiwrčean ${ }^{70}$ composed his scandalous writing against the then patriarch of Constantinople Awetik' Evdokiac'i (1657-1711), who, enjoying the patronage of Sheykh-ul-islam Feyzullah Efendi, waged "a holy war" against all the Catholic Armenians."71 According to Komitas, Awetik' solicited money from the aged prelate of Bursa, "theologian vardapet Suk'ias... the disciple of Catholicos Ełiazar..."72 under the threat of being accused of Catholicism and detention. Komitas testifies that "Suk'ias being feeble in his body and grown old... expecting his death any minute" was not able to pay; instead he temporarily won the patriarch over by sending him small gifts. ${ }^{73}$ It was deemed that Suk'ias eventually was confined in jail and could redeem himself only by paying. ${ }^{74}$ Our main source Komitas makes no mention of Suk'ias's imprisonment. ${ }^{75}$

Importantly, in 1707 we find Komitas harbored by Suk'ias in his house in Bursa a couple of weeks before the former's martyrdom, suggesting that at this point Suk'ias was still the prelate of Bursa. ${ }^{76}$ Echoing Mik'aēl Č'amč'ian, Maghak'ia Ōrmanian considers Suk'ias not to have been guilty of what he was accused of, whereas Eremia's polemical writing against him seems to prove his pro-Catholic sympathies. Suk'ias's confessional affiliation remains ambiguous in his actions: in 1702-1703, still persecuted by Awetik', Suk'ias copied for his personal use, a voluminous collection consisting of the writings of Nersēs Šnorhali (d.1173) and Nersēs Lambronac'i (d. 1198), theologians of the Apostolic Church in the Cilician period, both of whom were famous in Catholic circles for their alleged efforts towards formal union with Byzantine, and then Latin

70 According to Minas Hamt'ec'i's Diary Komitas was in Jerusalem till 1701. Minas does not record the date of his return to Constantinople. Based on Minas's account Mesrop Nshanian disproves Father Meserianc"s assumption that Komitas was persecuted by Awetik' as a crypto-Catholic and found refuge in Jerusalem. Komitas was very attached to Minas Hamt'ec'i and accompanied him in his trip to Jerusalem. K'ēōmiwrčean, Ōragrut'iwn, Introduction, 84, n. 1.

71 For the most recent research on Awetik's controversy with Armenian Catholics, see Cesare Santus, "The Şeyhülislam, the Patriarch and the Ambassador: A Case of Entangled Confessionalization (1692-1703)," paper presented at Entangled Confessionalizations, Budapest, June 1-3, 2018.

72 BnF Arm. 334, f. 44v.

73 BnF Arm. 334, f. 44v.

74 Č'amčian has couple of sentences on Suk'ias's imprisonment. Č'amčian, Hayots' patmut'iwn, vol. 3, 735. Following Č'amčian, Henry Riondel writes: "Sous Avédik, il avait connu la prison d'où il n'était sorti qu'en déboursant force piastres," in Henry Riondel, Une Page Tragique de l'Histoire Religieuse du Levant: le Bienheureux Gomidas de Constantinople Prêtre Arménien et Martyr, (Paris: Beauchesne 1929), 130.

75 Č'amčian wrote this paragraph majorly grasping from Komitas K'ēōmiwrčean's accounts without mentioning his source, while Maghak'ia Ōrmanian just quotes Č'amč'ian's text.

76 Riondel, Une Page Tragique, 130. 
Churches on the grounds of preservation of the doctrine and the rite of the Armenian Church. ${ }^{77}$ Suk'ias's collection included also homilies on the refutation of mixed chalice and purgatory, which testifies to his orthodoxy from the point of view of the Armenian Apostolic Church. In one of his theological poems Suk'ias transmitted the doctrine of the Armenian Church into versed form. In fact, it is "the canon of the orthodox faith" in rhythm and metrics, without any trace of "schism." 78 Speaking on the procession of the Holy Spirit, Suk'ias puts forth a formula acceptable to both the Apostolic and Catholic Armenians: "Is not teeming as created, but [is] processing // Holy Spirit moved from the Father (in)to the Son unchanging."79 The poem is an acrostic dedicated to his "beloved Ğendi Zade Nimetullah Çelebi" (Łēntizatē Neymēt'ulah Č'elepi)—a nobleman in Aleppo. ${ }^{80}$

And again, Suk'ias's friendship with converted Komitas K'ēōmiwrčean and Minas Hamt'ec'i, who were suspected of holding pro-Catholic views, suggests his being quite open to Catholicism. On the other hand, his close connections to such conservative clerics and laics as Ełiazar and Eremia, and his commissioning of non-Chalcedonic theological codices, prove his support of the nonChalcedonic faith. Even though Ełiazar, like both his predecessor on pontifical throne Yakob J`ułayec'i and successor Nahapet Edesac'i, were at times accused of dubious attitude towards Catholics, it was rather a political choice rather than personal disposition. Since these choices never affected the doctrine and practice of the Armenian Church, Eremia rejects the tiniest possibility of Suk'ias's "bad innovation" to be inherited from Etiazar. ${ }^{81}$

77 See J936 in Połarian Mayr C'uc'ak, vol. 3, 472-479. This notion of Nersēs Šnorhali and Lambronac'i being active agents for the unity with Chalcedonic Churches is ensued by the Teatine missionary to Armenia Clemente Galano (1611-1666), who attempted to prove that Armenian Apostolic Church has been one with the Roman Catholic Church. Since it fell into a schism in different historical periods Armenian "orthodox" high-ranking clergy, such as Šnorhali and Lambronac'i, attempted to reconcile it with Rome. Galano's treatise became a yardstick against which the "orthodoxy" of the Armenians was being tested among the Catholics. See, Clemente Galano, Consiliationis Ecclesiae Armenae cum Romana, t. 1-2, (Romae: Typis de Propaganda Fide,1650, 1658, 169o).

78 M1635, f. $57 \mathrm{v}-69 \mathrm{r}$.

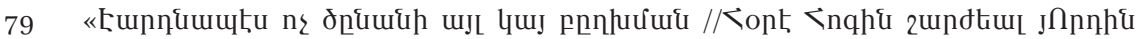
unlyujulyui», M1635, f. 58 r. Such a formulation could not be defined as the doctrine of Filioque; it rather resembles the ancient doctrine of Perikhoresis ( $\pi \varepsilon \rho \iota \omega^{\prime} \rho \eta \sigma \zeta ;$ circumincession) - the eternal relationship of the persons of the Holy Trinity.

80 It seems that Nimetullah, whose personality is yet to be identified, played a significant role in internal life of the Armenian community in Ottoman realms. Eremia K'ēōmiwrčean, with whom Nimetullah was in touch, calls him "İzzetli ve ürüfetli efendim" [My honorable and reverend master]. See, K'ēōmiwrčean, Óragrut'iwn, 517-519. 
Eremia's relationship with Suk'ias Prusac'i has never been fully studied. Eremia had intimate acquaintance with Suk'ias as he used to be Eliazar's student and frequently spent time with both of them in Constantinople, Bursa, Jerusalem and elsewhere. ${ }^{82}$ Apparently, like Eliazar, Suk'ias was welcomed in the house of the K'ēōmiwrčean family, for Martiros and Komitas K'ēōmiwrčeans were closely related to him. However, their ostensibly amicable relations did not hinder Eremia from rebuking Suk'ias for the prohibition of the Nicene Anathema, which he considered a transgression against the Apostolic rite.

The date of Suk'ias's death remains obscure. Two manuscript colophons copied in 1721-1734 from his personal codices mention neither his life nor death. The only hint is found in the collection of his poems, where the last-a poem of penitence, death and its desperation-is dated to $1707 .{ }^{83}$ One of the most learned and influential agents of the Armenian Church in the confessional age found himself in deep depression towards the end of his life. Upon Suk'ias's passing his memory fell into oblivion overshadowed by the fame of his patron Eliazar Aynt'apec'i. If not for Eremia Č'ēlēpi's polemic piece, we would likely never learn much about him or be able to detect confessional ambiguity behind his exterior orthodoxy. Moreover, Suk'ias's attempts to infuse a "novelty" into the practice of the Armenian Church would have remained totally unknown. Before turning to the analysis of the arguments that Eremia K'ēōmiwrčean set forth against the "novelty" imposed by Suk'ias, it is important to trace the causes that prompted Eremia to insist on the recitation of the Nicene Anathema.

In his letter to the friends in T'ekirdał (Rodosto) written in 1692, shortly after he visited there with his son vardapet Grigor, Eremia Č'èlēpi recalls a party in the house of an Armenian named Pōłos, where a discussion over religious topics took place.$^{84}$ It seems that a certain Xoja Malxas, who, according to Eremia, used vulgar language and was totally ignorant of theological matters, started a discussion on the decrees adopted during the Seventh Ecumenical Council. ${ }^{85}$

\footnotetext{
82 On Sunday, November 6 in 1653 Eremia and his family took vekil Suk'ias and Małak'ia Č'èlēpi, the son of Xoǰa Eremia Hamt'ec'i to Galata and from there to Balat to perform the ceremony of matrimony in an Armenian church. K'ēōmiwrčean, Ōragrut'iwn, 47-48.

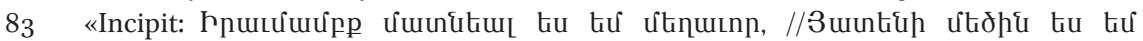

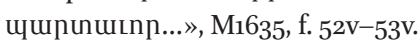

84 K'ēōmiwrčean, Ōragrut'iwn. Appendix, 543-549.

85 The Seventh Ecumenical Council, known as Second Council of Nicaea, summoned in 787 has never been recognized by the Armenian Church.
} 
Supposedly Xoǰa Malxas opened a discussion about the "valid" confession of faith. Eremia, who was trying to evade provocative questions and to keep the peace between the arguing parties, suddenly stepped in claiming that true belief had already been formulated in the Nicene Creed, and anything else is considered dubious:

\section{SnıwL uwhưư unเpp husunnju,

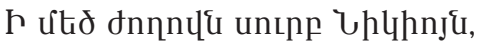

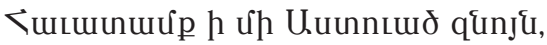 \\ Łinhwintn uqqp nunntutinju \\ [The] definition to holy faith was given, \\ In the great holy Council of Nicaea, \\ The same "We believe in One God" \\ Accepted by all the nations. ${ }^{86}$}

Eremia reproaches his friends in Rodosto for not having paid decent heed to his son vardapet Grigoris's preachings, instead every illiterate laic imagined himself a theologian. Eremia even humors Xoǰa Malxas for his name ("makas"- scissors in Turkish), for his vulgarity and ignorance and expresses his preoccupation about the growing attention to Malxas being an attack on the real teachers of the faith. This incident in Rodosto reveals that by 1692 debates on confessional topics had gradually become part of everyday life. Society had become more sensitive to the issues related to "true" confession of faith and more and more laymen, in particular, the xojas, had become integrated into theological discourse. Such intense discussions brought about acute creedal controversies among diverse clusters of society, such as how Eremia begins his letter to Rodostians with the quote from the Gospel of Matthew "blessed are the peacemakers" (Mat. 5:9).87

Creedal controversies within Armenian communities of the Ottoman Empire were intensified due to the abundance of diverse creeds and confessions of faith circulating among Armenians in this period that were generated

86 K'ēōmiwrčean, Ōragrut'iwn. Appendix, 548. Here and elsewhere in the text the word "nation" signifies "religious community" (millet).

87 The biblical verse from Matthew will later become an epigram for many polemical writings composed against Catholics and vice versa in the early eighteenth century such as Gēorg Mxlayim's Xatatarar meknut'iwn eketec'woy [Peacemaking Interpretation of the Church], M1464, and Stepanos Daštec'i's Kočnak čšmartut'ean [Clapper of Truth], M781. 
both in the Apostolic and Catholic milieu. ${ }^{88}$ The first Armenian codex entitled Confession of Faith was published in 1688, with the blessing of the then Catholicos Ełiazar Aynt'apec'i. It was rather a polemical book narrated by Yovhannēs Mrk'uz J'ułayec'i (1643-1715) in the form of a catechism. ${ }^{89}$ Its second edition was published in 1713-14 during the tenure of Catholicos Alek'sandr J'ułayec'i (1707-1714). The new publication was informed by the fierce confrontation of the Armenian Apostolic faction with the Catholic Armenians in Constantinople. In contrast, the Catholic confessions such as the Dawanut iwn Čšmarit ev Uttap'ar Hawatoy vasn Arneloy Ekelec'n Yarevelic' (Confession of the True and Orthodox Faith to be Accepted in the Church of East) were abundantly circulating in the Catholic Armenian intellectual circles. Among the first published after the Council of Trent, was a bilingual Professio Orthodoxae fidei published in 1596 by the order of Pope Clement VIII (1592-1605) for the Armenian converts. ${ }^{90} \mathrm{~A}$ later and more extended edition was published in 1642 during the tenure of Pope Urban VIII (1623-1644), bringing it in accordance with the decrees of the Council of Trent. ${ }^{91}$ The 1678 edition, published the Dawanut iwn Uttap'ari Hawatoy i Yamenic' Hayoc'Arneloy (Profession of Orthodox Faith to be Accepted among All Armenians) which greatly differs from that of 1642 in that the text's technical terms translated from Latin resulted in a new vocabulary, closer to the one used in the 1670 . $^{92}$

88 For definitions and distinction between the creeds and the confessions of faith, see Jaroslav Pelikan, Credo: Historical and Theological Guide to Creed and Confessions of Faith in the Christian Tradition (New Heaven and London: Yale University Press, 2003), ${ }^{1-5}$ and $35-36$. For the use of catechism in Europe, see Stefan Ehrenpreis, "Teaching Religion in Early Modern Europe: Catechisms, Emblems and Local Traditions," in Religion and Cultural Exchange in Europe,1400-1700, eds. Heinz Schilling and István György Tóth (Cambridge: Cambridge University Press, 2006), 256-273.

89 See Girk' hamarīt vasn iskapēs ew čšmarit Hawatoy [A Brief Book on the True and Veracious Faith] (New Julfa: Surb P'rkičc Print, 1688).

90 For the confession of faith, see Brevis Orthodoxae fidei professio, qaue ex praescripto Santctae Sedis Apostolicae ab Orientalibus ad Sacrosanctae Romanae Ecclesiae unitatem venientibus facienda proponitur, (Romae: Typographia Vaticana, 1596). On the causes of Councils of Trent and Tridentine terminology, see John W. O'Malley, Trent and All That: Renaming Catholicism in the Early Modern Era (Cambridge, MA: Harvard University Press, 2000).

91 Professio Orthodoxae fidei ab Orientalibus facienda (Romae: Typis de Propaganda Fide, 1642), 20-21.

92 Professio Orthodoxae fidei ab Orientalibus facienda (Romae: Typis de Propaganda Fide, 1678). The change in translated theological terms might be seen when juxtaposing the versions of Professio Fidei from 1642 and 1678, for instance «h hujnf ứtumlum [» vs «h

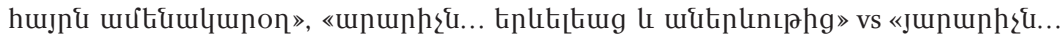

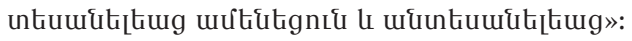


During this period, various types of medieval confessions and creeds were circulating within the Armenian theological community. Apart from the most authoritative liturgical version of the Nicene Creed, there was a confession of faith formulated in the thirteenth century by Vardan Arewelc'i (d. 1271) upon the request of Catholicos Konstandin Barjrberdc'i (1221-1267) against Byzantine duophysites. However, this confession never gained so much popularity so as to be recited in the churches. ${ }^{93}$ Since the fourteenth century the Armenian Church has favored a creed attributed to Grigor Tat'ewac'i (13461409) - the pinnacle of Armenian scholastic thought—structured in a way so as to oppose the Dominican Unitor Friars and Muslims in Eastern Armenia. It incorporated the Nicene Creed with the important amendments emphasizing the doctrines of the Trinity against the Seljuk Muslims. ${ }^{94}$ Grigor Tat'ewac'i's creed also included: the procession of the Holy Spirit solely from the Father against the Filioque (procession also from the Son); the one nature of Christ against the duophysites; His real body "from the blood of Holy Mother of God" against the phantasists; his immaculate and virgin birth; his perfect Deity and perfect Humanity; and the Harrowing of Hell and the eternal punishment of the sinful. In a fifteenth-century manuscript, the scribe calls this particular creed "the true confession of faith of the Armenian Church," while its articles are described as "the gradations of faith through which we ascend to God with one footstep."95

The variants of Grigor's creed became extremely popular in the age of confessionalization. Due to its popularity it was included in collections such as the confessions of faith assembled by Marquise de Nointel, where there is an

93 The profession of faith attributed to Vardan Arewelc'i is structured in a way so that each rubric of it starts with "We believe" (Credimus). It touches upon all debatable confessional issues. Arewelc'i's confession of faith was not popularized or read aloud in the churches. See Vardan Arewelc'i, "Dawanut'iwn hawatoy ułłap'arut'eamb srboy vardapetin Vardanay i xndroy srbazan kat'ołikosin hayoc' Kostandeay" [Confession of Orthodox Faith by Saint vardapet Vardan upon the Request of Armenian Catholicos Konstandin], Gandzasar Theological Review 7, (2002): 371-384.

94 For Armenian-Muslim interactions in the Middle Ages, see Sergio La Porta, "Conflicted Coexistence: Christian-Muslim Interaction and its Representation in Medieval Armenia" in Contextualizing the Muslim Other in Medieval Christian Discourse, ed. J. C. Frakes (Palgrave: McMillan, 2011), 103-123; and "Gregory of Tat'ew" in Christian-Muslim Relations. A Bibliographical History. Volume Five (1350-150o CE), ed. David Thomas, Alexander Mallett, et. al. (Leiden: Brill, 2013), 229-238. Current scholarship on the polemics of Grigor Tat'ewac'i's with the Muslim world can be found in Seta Dadoyan, The Armenians in the Medieval Islamic World: Paradigms of Interactions Seventh to Fourteenth Centuries (New Brunswick and London: Transaction Publishers, 2014), 187-221.

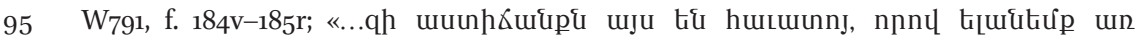

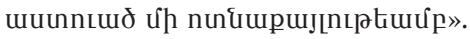


attestation of faith obtained via Ambroise de Tiger, French Consul to Egypt and signed in 1671 by Gaspar, the prelate of the Armenian Church in Cairo. ${ }^{96}$ In contrast to all other attestations collected from high-ranking officials of the Armenian Church, the confession provided by Gaspar stands out. Drawing entirely on Grigor Tat'ewac'i's creed, it includes the addition of major counterpoints against the Protestants in the vernacular-that is the veneration of saints and the Virgin, iconolatry, perception of the Seven Sacraments and Eucharistic transubstantiation. ${ }^{97}$

A few years later in 1676 the English Consul to Izmir, Sir Paul Rycaut wrote the following about the confession of faith of the Armenians:

96 For the English translation of Tat'ewac'i's Creed, see Dadżad Tsaturyan, "The Creed of Armenian Apostolic Church According to Saint Grigor of Tat'ev," Warszawskie Studia Teologiczne 28, no. 4 (2015): 103-104. For the confession of faith provided by Gaspar see BNF Arm. 145, f. 3 O and BNF Arabe 227.

97 Interestingly called "confession articulated by saint Grigor our Lusaworič":

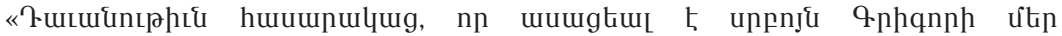
Lnjumjunn々hi». Apparently, there was a confusion of the names of Grigor Tat'ewac'i and Grigor Lusaworič. The text does not use the Armenian word «qnumunhunцphц\{» (goyap'oxut'iwn) for transubstantiation but replaces it with the sentence "We believe [that] body and blood of Christ in the hands of priest are visible bread and wine, when the priest performs the sacrament, at the very moment it turns into the body and blood

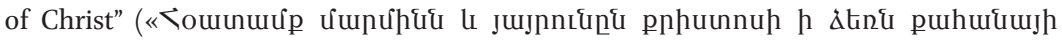

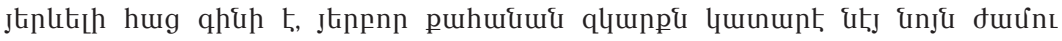

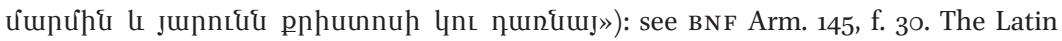
translation of Gaspar's attestation of faith does not use transubstantiatio, either; instead there stands transmutantur in Corpus et Sanguinem Jesu Christi: see BNF Arabe 227. Other attestations of faith collected by Marquis de Nointel following the textual pattern partly designed by Hilarion Kigalas (1624-1682) and almost identical with the Greek professions

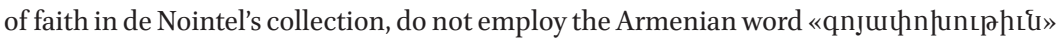

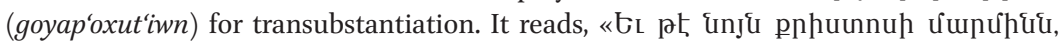

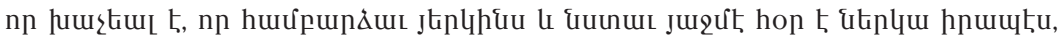

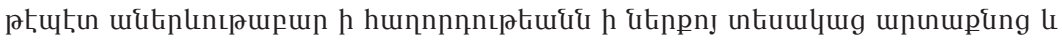

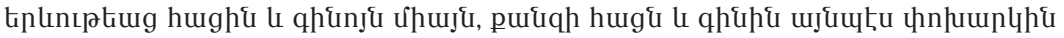

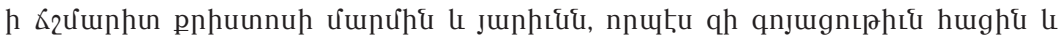

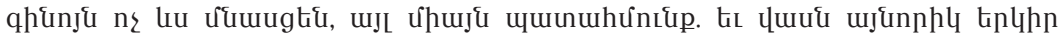
щшquitiup pnhuunuh nin hunnnnnıрtiu\{»: see BNF Arm. 145, f. 7. The French translation also refrains from the use of transubstantiatio: "Lequel Corps a été crucifié, est monte au Ciel où il est assis à la droite du père, et qu'il est réellement presence quoique invisiblement dans l'Eucharistie sous les espèces et les apparences extérieures du pain et du vin parce que le pain et le vin sont changés au Corps et au Sang de Jésus Christ de façon qu'il ne reste plus de substance du pain et du vin, mais seulement les accidents. C'est pourquoi Nous adorons Jésus Christ dans L'Eucharistie": see BNF Arm. 145, f. 9. 
They allow and accept the Articles of Faith according to the Council of Nicaea, and are also acquainted with that which we call the Apostles Creed, which likewise they have in use... I have thought fit to represent that which they call their Tavananck, or Symbolum, different from the Apostles and Nicene Creed... Now the words of their Creed are Verbatim as followeth...98

Sir Rycaut's reference here is to a variant of Grigor Tat'ewac'i's creed with the addition of the clause on postpartum virginity of the Holy Mother of God. To highlight the popularity of this creed among Armenians, Sir Rycaut states that Armenians repeated the Creed, "in the same manner as our Apostles Creed is in our Divine Service." 99 This version has one essential difference: instead of collective "We believe" (Credimus), here the Western "I believe" (Credo), apparently in accordance with the Western creedal fashion of the confessional age and the emphasis on the personal interiorization of faith, makes an appearance. ${ }^{100}$ Yovsēp Gat'ěrčian reckoned Sir Rycaut to be misled by his cleric companion, who, instead of the Nicene Creed presented Grigor's creed as the accepted confession of faith of the Armenians. ${ }^{101}$ Perhaps, in some monasteries in Safavid Armenia the recital of this creed might have been preferred over the liturgical version of the Nicene Creed, as there are sources alluding to its inculcation into the Armenian Liturgy by the middle of the eighteenth century. ${ }^{102}$

Towards the end of the seventeenth century, new ecclesiastical policy attempted to oust all the creeds but the Nicene one, which was implemented in order to stem the creedal polyphony and preserve the integrity of Armenian

98 Paul Rycaut, The Present State of the Greek and Armenian Churches (London: Printed for John Starkey, 1679, reprint. New York: ARM Press, 1970), 409-411. Yovsēp Gat'ěrčian gives the Armenian version of this variant in, Hanganak hawatoy orov vari Hayastaneayts" eketec'i. K'nnut'iwn hanganakin cagman, hetinakin ev žamanakin veray [The Creed that the Armenian Church Follows: Research on the Origins, Author and Time of the Creed] (Vienna: Mekhitarist Press, 1891), 40-41.

99 Rycaut, The Present State, 415. The text of the confession is on pages 411-414. Paul Rycaut compares the Christological passages of this creed relating to the real body of Christ with the passage in the Anatolian Confession promulgated by Greek patriarch of Jerusalem Dositheos II in 1672 to prove that the Armenian Church has never been monophysite, but rather miaphysite.

100 On the topic, see Pelikan, Credo, 35-36.

101 Gat ěrčian, Hanganak hawatoy, 40.

102 A very brief version of Tat'ewac'i's creed summarized in the fourteen articles as "gradations of faith" and starting with "I believe" is found in an eighteenth-century manuscript at the Matenadaran M8444, f. 377r-v. Nowadays, Tat'ewac'i's creed is chanted only at the Sacrament of the Holy Orders both in the Armenian Apostolic and Catholic Churches. 
orthodoxy. Church authorities conformed to the old Armenian liturgical version of the Nicene Creed, that had been recited in the Armenian Church for ages. This creed was proclaimed as the only true formula of faith by appealing to its pre-Chalcedonic origin and to the uninterrupted tradition of its recital during the Divine Liturgy. Consequently, Eremia K'ēōmiwrčean strove to single out the Nicene Creed as the only formula of Armenian faith to counterpoise the multitude of the variants of Grigor's creed as well as to resist against the spread of the Armenian version of the Tridentine and Apostles' Creeds. ${ }^{103} \mathrm{~A}$ later author, Gēorg Mxlayim Ōłi (d. 1758), was a fervent advocate of such mono-creedal policy; polemicizing with the Jesuits, he highlighted that the sole credo to which the Armenians had adhered through the centuries was the Nicene Creed in its ancient liturgical version. ${ }^{104}$ This prompts several questions: What was the Armenian liturgical version of the Nicene Creed? Why did it become a matter of dispute in the confessional age? And why would Eremia K'ēōmiwrčean insist on its exclusive credibility?

\section{Multiple Facets of the Symbol of Faith: the Nicene Creed under the Magnifying Glass}

Creeds, as the rule of prayer, have always been the integral part of the Divine Liturgy as the rule of faith in accordance with the formula lex orandi lex credendi (the law of prayer is the law of belief). ${ }^{105}$ The liturgical versions of the creeds actually recited or chanted during the Divine Liturgy differ from the officially promulgated formulas of faith, such as the variants of the Nicene Creed in the Psalters and Massora of the Syriac Churches, be it in Western Syriac Church or in the Church of East (Nestorian). ${ }^{106}$

The liturgical version of the Nicene Creed of the Armenian Church or the socalled Faith of the YŽ̈ $(318)$ Fathers, is an "enlarged" version of the Nicene Creed promulgated at the First Ecumenical Council in Nicaea in 325. The original Nicene Creed was followed by the Nicene Anathema against the fourth-century heresiarch Arius and his teaching on the Holy Trinity, that is:

\footnotetext{
103 For a version of the Tridentine Creed in Armenian with additions and marginal notes, see manuscript in the Library of Mekhitarist Congregation in Vienna, W1595, f. 1-4.

104 See Matenadaran manuscript M1464, f. 97r-98v.

105 Pelikan, Credo, 178-184.

106 William Emery Barnes, “The 'Nicene' Creed in the Syriac Psalter," The Journal of Theological Studies 7, no. 27 (1906): 441-449; Willem Baars, 'The "Nicene' Creed in the Manuscripts of Syriac Massora," The Journal of Theological Studies 13, no. 2 (1962): 336-339.
} 


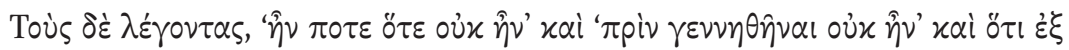

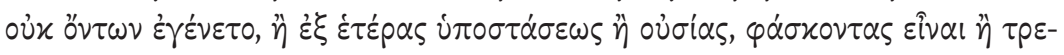

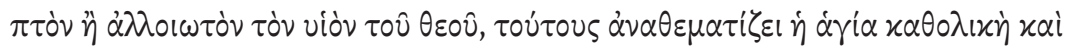
$\dot{\alpha} \pi \circ \sigma \tau 0 \lambda \mid x \dot{\eta} \dot{\varepsilon} \kappa x \lambda \eta \sigma \dot{\alpha} \alpha$.

And those who say 'there once was when he was not,' and 'before he was begotten he was not," and 'that he came to be from things that were not,' or "from another hypostasis or substance," affirming that the Son of God is subject to change or alteration-these the catholic and apostolic church anathematizes. ${ }^{107}$

The Nicene Creed was reaffirmed at the Second Ecumenical Council summoned in Constantinople in 381 with the addition of the third article on the divinity of the Holy Spirit and exclusion of the Nicene Anathema. In fact, the creed promulgated in Constantinople had little to do with the original Nicene Creed. According to scholarly opinions, it used to be a baptismal creed already in use among the Christians of Jerusalem, and was elaborated during the Council. Its working title is Niceno-Constantinopolitan Creed professed by the Orthodox, Catholic and some Protestant Churches. ${ }^{108}$

Although the Armenians accepted the decrees of the first three Ecumenical Councils, the Niceno-Constantinopolitan Creed has never been incorporated into the liturgical tradition of the Armenian Church. Instead, an "enlarged" version of the original Nicene Creed became common. The testimonies to the usage of this version by the Armenians could be traced back to the early sixth century. ${ }^{109}$ The Creed is based on the section appearing in the 119th chapter of Ancoratus by Epiphanius of Salamis (ca. 315-403), known to the specialists as the second creed of Epiphanius. ${ }^{110} \mathrm{He}$ composed it in 374 and placed right after the Nicene Creed as its enlarged explanatory variant with the anti-Apolinarian

107 Original and translation cited here as they appear in Creeds and Confessions of Faith in the Christian Tradition, ed. Jaroslav Pelikan and Valerie R. Hotchkiss, vol. 1 (New Heaven and London: Yale University Press, 2003), 158-159.

108 J. N.D. Kelly, Early Christian Creeds (Contiuum, 1972), 311. Creeds and Confessions, 100. Catholic Church professes a Western Recension of the Niceno-Constantinopolitan Creed with addition of the Filioque.

109 Gat'ěrčian, Hanganak hawatoy, 2-4.

110 For a critical edition of Ancoratus, see Epiphanius: Ancoratus und Panarion, ed. K. Holl (Leipzig: J. C. Hinrichs'sche Buchhandlung, 1915), 1-149. For the English translation, see Richard Kim Young, Saint Epiphanius of Cyprus: Ancoratus, in The Fathers of the Church, vol. 128 (Washington: The Catholic University of America Press, 2014), 51-227. For the original see Holl, Epiphanius, 148-149. 
and anti-Macedonian additions. Like the original Nicene Creed, Epiphanius's second creed ends with an Anathema:111

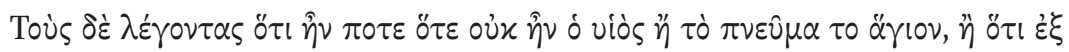

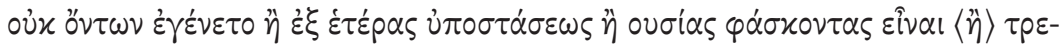

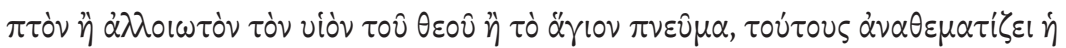

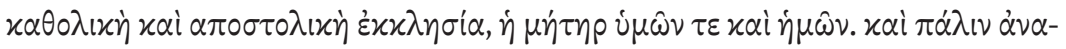

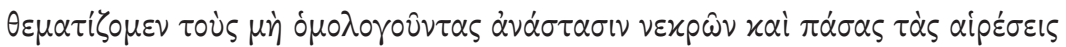

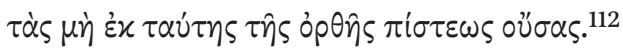

And those who say that there was a time when the Son was not, or when the Holy Ghost was not, or that either was made of that which previously had no being, or that he is of a different nature or substance, and affirm that the Son of God and the Holy Spirit are subject to change and mutation; all such, the catholic and apostolic church, the mother both of you and of us, anathematizes. And further we anathematize such as do not confess the resurrection of the dead, as well as all heresies which are not in accord with the true faith. ${ }^{113}$

The Armenian liturgical version of the Nicene Creed, though not identical, largely follows Epiphanius's enlarged variant. It retains the Anathema and adds to it a doxology attributed to Grigor Lusaworič" (Gregory the Illuminator). In the age of confessionalization this version was frequently called the Creed of Lusaworič - an allusion to the narrative, according to which Grigor Lusaworič"s son Aristakes brought its Greek original from Nicaea, while Grigor Lusaworič rendered it into Armenian. According to the narrative he also translated the Nicene Anathema, which is as follows:

111 The Greek original preserved a text almost identical to the Niceno-Constantinopolitan Creed. Scholars agree that it was a later insertion in Epiphanius's text and that Epiphanius most probably quoted the Nicene Creed rather than Niceno-Constantinopolitan: see Kelly, Early Christian, 318-320; also Creeds and Confessions, 100. Athanasius of Alexandria's letters to bishop Serapion arguably served as a source for Epiphanius's second creed. On this basis Yovsēp Gat'ěrčian assumes the Armenian liturgical version to be Niceno-Athanasian (not to confuse with the Athanasian or pseudo-Athanasian Creed): see Gat'ěrčian, Hanganak hawatoy, 34-37.

112 Holl, Epiphanius, 149.

113 The most recent translation is prepared by Young in Saint Epiphanius, 227. I rely on Philipp Schaff's translation which is closer to the Armenian variant in its archaic wording: see Philipp Schaff, Nicene and Post-Nicene Fathers: The Seven Ecumenical Councils, Series II, vol. 14 (Peabody, MA: Hendirckson Publishers, 1994), 165. 


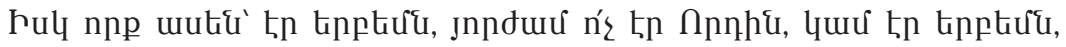

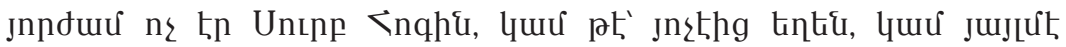

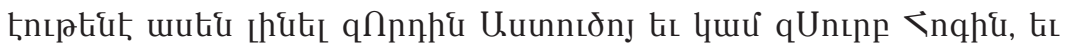

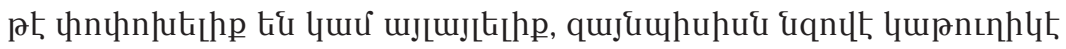
tis unuptidulutu untpp tiltingh:

As for those who say "there was a time when the Son was not", or "there was a time when the Holy Spirit was not", or that "they came into being out of nothing"; or who say that "the Son of God or the Holy Spirit are of a different substance" and that "they are changeable or alterable," such do the catholic and apostolic holy Church anathematize:

Doxology by Grigor Lusaworič‘:

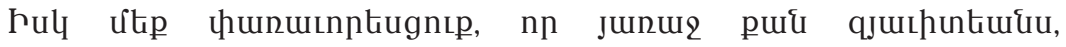

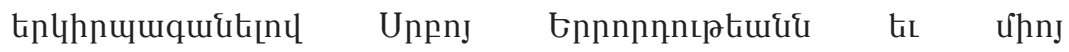

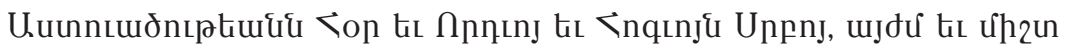

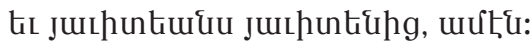

As for us, we shall glorify him who was before the ages, worshipping the Holy Trinity and the one Godhead, the Father and the Son and the Holy Spirit, now and always and unto the ages of ages. Amen. ${ }^{114}$

Another anecdotal narrative circulating in the Armenian Catholic circles up to the nineteenth century suggests that all the amendments to the Armenian liturgical version of the Nicene Creed, including the addition of the third article on the Holy Spirit promulgated at the Council of Constantinople, were made later by the Armenian Catholicos Nersēs. ${ }^{115}$ Adding "novelties" to the Creed was not unprecedented in the Armenian ecclesiastical tradition, thereby justifying supplementation of the Fillioque to the Niceno-Constantinopolitan Creed decreed at the Council of Ferrara-Florence (1438-1439).116 In his reply to an unknown addressee upon the request to explain the origin of the Armenian liturgical version of the Creed, a Constantinopolitan Armenian Catholic priest writes:

114 The Divine Liturgy of the Armenian Church: English Translation, Transliteration, Musical Notation, Introduction and Notes, ed. Daniel Findikyan (New York, 2005), 19.

115 It is not clear which Catholicos Nersēs the narrative refers to.

116 For the short-lived Bull of Union with the Armenians of the Council of Florence, see Creeds and Confessions, $755^{-765}$. 


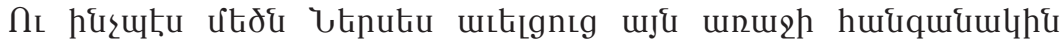

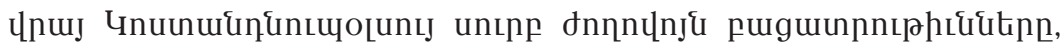

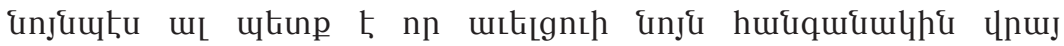

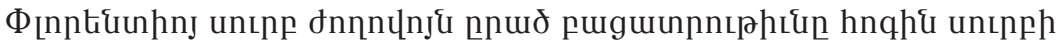
цnшj' lu nnnınju phup:

And as Great Nerses amended that first Creed, with the explanations of the Holy Council of Constantinople, the same way the explanations on the Holy Spirit of the Council of Florence, that is Filioque, should be added to the same Creed [Ms W111, f. 75].

Interestingly, the Bull of Union with the Armenians promulgated at the Council of Ferrara-Florence imposed upon the Armenians the Western Recension of the Niceno-Constantinopolitan Creed as the rule of prayer to be sung or recited during the Divine Liturgy in Armenian churches, and the Faith of St. Athanasius or pseudo-Athanasian Latin Creed as the rule of faith to be professed as the official declaration of Christian doctrine. ${ }^{117}$ The Council's choice to make the Niceno-Constantinopolitan Creed incumbent on the Armenians testifies to the disuse of this specific creed during the Divine Liturgy of the Armenian Church up to the fifteenth century. Driven by the necessity to refute various accusations of being Eutychean-minded monophysites, the Armenians employed Epiphanius's enlarged variant of the Nicene Creed - penned seven years prior to that of the Niceno-Constantinopolitan-by incorporating passages against the "heresies" of which the Armenian Church was historically accused.

In his aforementioned letter to his friends in Rodosto, Eremia K'ēōmiwrčean undoubtedly speaks of the Armenian liturgical version of the Nicene Creed. Later he includes this version in his catechism compiled for an Armenian Catholic priest T'adēōs Hamazaspean by having changed the archaic wording "Inju hupu h puntptiut, hnp" ("of the same nature of the Father") that

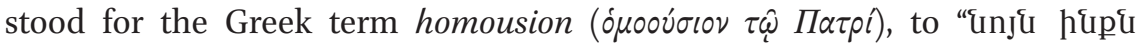
huưuqnjulhg hnp" ("consubstantial with the Father"), as well as adding "nn h hopt lu jnnnın pnhup" ("ex Patre Filioque") in due place. ${ }^{118}$ Apparently Eremia was driven by interest in preservation of the "Armenianness" of the Catholic Armenians along with their confessional affiliation. Therefore, he capitalizes on the Nicene Creed to prove ethnic identity to be more important

117 Creeds and Confessions, 675-677, 757, 762, 764-765.

118 Museum of the All Savior Monastery in New Julfa, NOJ498, f. 12v-14r 
than a confessional one. Eremia retained the Anathema and Lusaworič's doxology at the end of the Creed for the use of the Catholic Armenians as a marker of their "Armenianness."

Eremia did not establish this creedal pattern, but rather followed the text in the missals printed for the Armenian converts to Catholicism. He arguably had access to the missals issued by De Propaganda Fide. ${ }^{119}$ A close examination of the missals printed by the Catholic Church "for the Armenian nation" reveals them to accommodate the Divine Liturgy of the Armenian Apostolic Church. Most of them preserved the Armenian liturgical version of the Nicene Creed with the insertion of "consubstantial with the Father" and ex Patre Filioque. The missal from 1677 and the one translated by Yovhannēs Holov into Italian in 169 o contain the Armenian variant of the Nicene Creed, the Anathema and the doxology. ${ }^{120}$ However, the earliest printed missal from 1646 inserts the Western Recension of the Niceno-Constantinopolitan Creed instead, excludes the Anathema, but retains Lusaworič's' doxology. ${ }^{121}$

The Nicene Anathema initially composed against the fourth-century Arians and Macedonians was the key element of the Armenian Divine Liturgy - "the seal of Nicene Faith," as it was called. Inherited through the enlarged variant of Epiphanius creed, it became an inseparable part of public prayer of the faithful implicitly designating the ethno-confessional identity of the Armenians. The recitation of the Nicene Anathema was the main indicator of confessional affiliation on the one hand and orthodoxy on the other. For instance, there is a famous story related to the renowned Dominican missionary to Safavid Armenia Paolo Piromalli, preserved in the Chronicle of Grigor Daranałc'i (d. 1643). The chronicler describes the inquisition of Piromalli, when he arrived in Constantinople in 1636 after being expelled from Ejmiacin by Catholicos P'ilipos Ałbakec'i (1633-1655). Piromalli lodged in the Galata district. Having dressed as an Armenianvardapet, he started proselytizing among the Armenian priests of the Surb Astuacacin ("Holy Mother of God") church gaining the favor of monks Xoǰa Davit and Kirakos J`ułayec'i. Therefore, the vardapets of Constantinople, with Daranałc'i in charge, sent the priest Łazar off to examine

119 For instance, see Liturgica Armena (Romae: Typis Sacra Congregatio de Propaganda Fide, 1677), 8.

120 La Dichiaratione della Liturgia Armena (Venetia: Apresso Michiel' Angelo Barboni, 169o), 18-20. Importantly, the Armenian Catholic translator Yovhannes Holov omits the line "and that they are changeable or alterable."

121 Ordo Divinae Missa Armeniaorum, (Romae: Typis Sacra Congregatio de Propaganda Fide, 1646), 46-49. This Missal was proofread and edited by Vinccentius Riccardus in 1636. Its Armenian translation was licensed to print by Giovanni Molino (Yovhannēs Ankiwrac'i), the translator of de Propaganda Fide. 
Piromalli's faith. According to Daranałc'i the only way to unmask Piromalli was to make him recite the Nicene Creed. Reaching the Anathema, Piromalli's refusal to recite "As for those who say" was considered apostasy from the perspective of the Armenian ecclesiastical traditions. Piromalli was expelled and banned from preaching in Armenian churches. ${ }^{122}$ It seems that the recital of the Nicene Anathema was not considered challenging for Armenian-Catholics, partly because of its inclusion into missals and catechisms, and partly because of their intimate familiarity with the rule of prayer of the Armenian Church. That said, in his letter from 1751 the Catholic Armenian priest from Mekhitarist order Gēorg Aynt'apc'i (d. 1794) informed his flock in Engür (Ankara), that before he arrived in Rome he thought that "apart from the anathema there are no schismatic rites in our nation." 123 In Rome he learned about other "schismatic" elements of the Armenian Apostolic rite, hence, exhorted his flock to give up communicatio in sacris with Apostolics. ${ }^{124}$

In the eyes of Eremia Čèlēpi, the banning of the recitation of the Nicene Anathema was not a matter of orthodoxy, but rather of orthopraxy. The 169 os were the years when Catholic Armenian priests would abstain from officiating in Catholic churches. They had to undergo the communicatio in sacris with the Armenian Apostolics, while clandestinely preaching and propagating Catholic ideas to the Apostolic faithful. On these grounds, Eremia Čélēpi assumed that the preacher, be he a crypto-Catholic or an Apostolic, should follow the rule of prayer of the Armenian Church if he preaches from its pulpits. From Eremia's point of view the recital of the Nicene Anathema was absolutely necessary for it was not only a yardstick for "Armenianness," but also the proof of the ancient roots of the Armenian liturgical tradition, and the mark of the continuity in its practice. The prohibition of Nicene Anathema by Suk'ias Prusac'i triggered Eremia Č‘ēlēpi's vocal criticism. He started a campaign against the "bad innovations."

The concept of religious "innovation" resonated across confessional boundaries in the Ottoman context at this time, as Muslims themselves, particularly in Constantinople, repeatedly clashed (sometimes violently) over the definition of "tradition" and accused each other of bid 'a, meaning harmful "innovation,"

\footnotetext{
122 Grigor Daranałc'i, Žamanakagrut'iwn [Chronicle], ed. Mesrop Nšanian, (Jerusalem: Saints James Press, 1915), 587; see also Henry Shapiro, "Grigor Daranalts'i: An Ottoman-Armenian Priest in the Age of Confessionalization." Paper presented at Entangled Confessionalizations, Budapest, June 1-3, 2018.

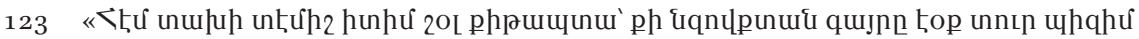

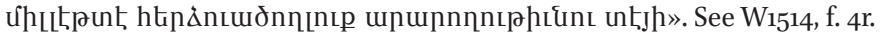

124 W1514, f. 3 r-4r.
} 
especially in the second half of the seventeenth century.125 The ideology of Ottoman "puritanism" modeled by Mehmed Birgivi (1523-1573) in his prominent book The Path of Muhammad, grew into active social and political movement in the seventeenth century by preacher Kadizade Mehmed b. Mustafa $(1582-1635) .^{126}$ The clashes between the "puritan" followers of Kadizade Mehmed and various other Muslims, often with affinities for Sufi rituals and beliefs, incited Katib Č‘ēlēpi (16o9-1657), a renowned Ottoman scholar, to reproach the Kadizadeli for the "spread of the extremist notions and provoking the people"-labelling the attempts to uproot established innovations in the community as stupidity. ${ }^{127}$ Along the lines of the "purification" movement of Ottoman Sunnis that found its expression in refutation of "bad innovations" (bid'a), the reshaping of tradition in line with "pure doctrine" and "correct conduct" grew into a common discourse in the Ottoman Christian milieu. As Eugenia Kermeli argues, "the Greek Orthodox scholars committed to the spirit of Renewal (avaxaivion), and challenged by Reformation and Catholicism, endeavored to redefine orthodox tradition in a sectarian manner, distinct from the Protestants and Catholics."128 Redefining of the tradition was not accepted by conservative Orthodox theologians and was labeled as "bad innovation"

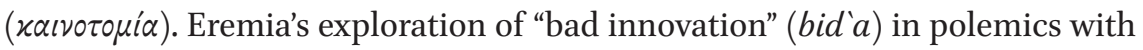
Suk'ias acquires great importance as it explicitly reveals deep engagement of Armenians with common processes in the Ottoman Empire.

The term "innovation" was more common for early modern Armenian theological vocabulary. Medieval Armenian authors, especially Eastern theologians, would opt for other words to point to the deviations from "orthodox" doctrine and practice. For instance, the twelfth-century polemicist Połōs Tarōnac'i uses the word batbanjank' ("idle talk") when he criticizes the Latin

125 Madeline C. Zilfi, "The Kadizadelis: Discordant Revivalism in the Seventeenth-Century Istanbul," Journal of Near Eastern Studies 45, no. 4 (1986): 251-269. See also Zilfi, The Politics of Piety: The Ottoman Ulema in the Post Classical Age (Minneapolis: Bibliotheca Islamica, 1988), 129-182.

126 Imam Birgivi, The Path of Muhammad: A Book on Islamic Morals \& Ethics, trans. Tosun Bayrak (World Wisdom, Inc., 2005). On the social and political aspects of the movement, see Marinos Sariyannis, "The Kadizadeli movement as a Social and Political Phenomenon: the Rise of a Mercantile Ethic?" in Political Initiatives from the Bottom-Up in the Ottoman Empire (Halcyon Days in Crete VII, A Symposium Held in Rethymno, 9-11 January 20og), ed. A. Anastasopoulos (Rethymno: Crete University Press 2012), 263-289.

127 Katib Çelebi, The Balance of Truth, trans. G. L. Lewis (London: Allen and Unwin Ltd., 1957), 89-91.

128 Eugenia Kermeli, “Kyrillos Loukaris' Legacy: Reformation as a catalyst in the 17th century Ottoman Society," The Muslim World 107, no. (2017): 748. 
doctrine of Filioque. ${ }^{129}$ Likewise, Grigor Tat'ewac'i (1346-1409), who lived on the relative verge of early modern era, utilized the word molorut iwn ("error") for Filioque and for other "heretical" doctrines. ${ }^{130}$ Tat'ewac'i lists not only the "errors" of the Latins and Byzantines, but also of Muslims. ${ }^{131}$

The Armenian word norajevut iwn ("innovation") appears in the Mistagogy of the Cilician theologian Nersēs Lambronac'i (1153-1198). He applies it to the rigorist, conservative conduct of Eastern Armenian vardapets, branding such rigorism as "neopraxy" ("novelty in practice"). ${ }^{132}$ The term acquires new connotation in the Ottoman context, where norajevut iwn ("bad innovation") was first explored by the Patriarch of Constantinople Grigor Kesarac'i. In his letter from 1630, addressed to the monks in Ejmiacin, he warns them against the Roman Catholic faith by calling it norajev banic'n ev nor atandoyn ("novel words and new heresy") and by considering it the revival of "the same Byzantine duophysit heresy."133 From the seventeenth century onwards "bad innovation" becomes closely connected with the concept of bid'a, denoting not only a schismatic doctrine, but also an incorrect conduct and transgression against canonical practice.

129 Połōs Tarōnac'i, T'utt' anddem T'êop'isteay horom p'ilisop'ayin [The Epistle against the Byzantine Philosopher Theopistus] (Constantinople: Č'nč'in Yovhannes Print, 1752), $84-86$.

130 Grigor Tat'ewac'i, Girk' harc'manc' [Book of Questions] (Constantinople: Astuacatur Kostandnupolsec'i Print, 1729), 61-62. For the Latin "list of errors," see Tia M. Kolbaba, Inventing Latin Heretics: Byzantines and the Filioque in the Ninth Century, (Kalamazoo: Medieval Institute Publications, 20o8). For a similar list for Byzantines, see Valentina Covaci, "Contested Orthodoxy: Latins and Greeks in Late Medieval Jerusalem," N.E.C. Ştefan Odobleja Program Yearbook, 2018-2019, 53-78.

131 For the "errors" of Muslims, see Grigor Tat'ewac'i's Against Tajiks in Babken Kyuleserian, Islamĕ hay matenagrut' ean mēj [Islam in Armenian Literature], (Vienna: Mkhitarist Press, 1930); Seta Dadoian, "Islam and Armenian Polemical Strategies at the End of an Era: Matt'ēos J̌ułayec'i and Grigor Tat'ewac'i1," Le Muséon, 114, no. 3-4 (2001), 305-326.

132 Nersēs Lambronac'i, "I xndroy hayc'manc' eric'akic' ełbarc' k'nnut'iwn kargac' ekełec'woy ew bac'atrapēs orošumn artak'ust mteal i sa norajevut'eanc' srboyn Nersēsi Lambronac'woy Tarsoni episkoposi." Xorhrdacut'iwnk' i kargs eketec'woy ev meknut'iwn xorhrdoy patarakin [Mystagogy on the Rites of the Church and Commentary on the Sacrament of the Divine Liturgy by Saint Nersēs of Lambron Bishop of Tarsus] (Venice: St. Lazzaro, 1847), 21-41.

133 See Arshak Alpoyajian, Grigor Kesarats'i patirark' ev ir zhamanakě [Patriarch Gregory of Caesarea and his Time] (Jerusalem: St. James Press, 1936), 158. 
In banning the recitation of the Nicene Anathema, Suk'ias Prusac'i might have been affected by the Jesuit propaganda in Bursa, which provoked immediate reaction in Armenian ecclesiastical circles, given that from 1612-1613 onwards, the prelacy of Bursa had become an influential center of Anatolia, housing a vast Armenian population. ${ }^{134}$ As a catechist, Eremia was perfectly aware that the Nicene Anathema was an essential part of practice, even in Armenian Catholic missals. Thus, the abolition of its recital by Suk'ias could pose a real threat to the orthopraxy of the Armenian Apostolic Church.

Against Suk'ias's "precarious novelty," Eremia polemicized in forty-one clauses. His polemics was informed by both social and confessional realities of his day, reflecting a view of the secular Armenian community. Eremia imparts first-hand information about the nuances of confessional switches, and the ambiguities and ignorance of confessional matters among his fellow Armenians. His main preoccupation seems to be the reputation of the Armenian Church. Eremia feared that the discontinuation of the recitation of the Anathema would call ridicule and outrage upon the Armenians, exposing the Armenian Church tradition on the whole as erroneous. ${ }^{135}$ For Eremia, the "pure doctrine" was rooted in the teachings of the Universal Church Fathers and decrees of the first Ecumenical Council that the Armenian Church had uninterruptedly preserved. Everything outside of these theological parameters was considered norajevut'iwn ("bad innovation"), and was $i$ čarēn ("from evil"). ${ }^{136}$

Eremia defined "bad innovation" as not something to be found exceptionally in doctrinal deviations from "true faith." For him, "bad innovation" referred to the disciplinary aspects of communal life. Eremia condemned Ełiazar Aynt'apec'i for the discord in the Armenian Church he brought about by having attempted to establish anti-Catholicosate driven solely by his egoistic ambitions. Above all, Eremia was concerned about the chain-reaction in the diffusion of "innovation": if it infected the community in Bursa, it would soon reach Constantinople, Edirne and other cities. His trepidation was hiding far behind his anticipation of the possible discord in the community. The unpleasant memories of the great turmoil in times of Ełiazar Aynt'apec'i were still fresh, and a new discord would shake the very grounds of ecclesiastical

134 Arshak Alpoyajian, "Kpōlsoy patriark'ut'iwnn u Prusayi, Ētirnēi ev Ŗotost'oyi arajnordut'iwnnerě" [Patriarchate of Constantinople and the Prelacies of Edirne, Bursa and Rodosto], in T'éodik's Amēnun tarets'oyts'ě [The Annuary of Everything], (Constantinople: Vahram ev Hrach‘ya Der-Nersesyani, 19o9), 209-214.

135 BNF Arm. 334, f. 146v.

136 BNF Arm. 334, f. 145r-v. 
life of the Armenians, should Suk'ias's teachings against Anathema be diffused. In view of this, Eremia recalled the turmoil in Jerusalem, hence, reproaching Suk'ias for imitating his patron's controversial behavior, and appealing to him to disseminate peace instead of discord.

According to Eremia, Suk'ias's position was even at odds with "pure" Roman Catholics - as they too agreed on the Armenian custom of reciting the Anathema to be useful in terms of definition of the "heresy." His arguments were saturated with Catholic sources, in particular, with passages from the treatise of Teatine missionary to Armenia Clemente Galano (d. 1666), whose words Eremia quotes to demonstrate the wide acceptance of the recital of the Anathema. In his two-volume bilingual edition about the history and doctrine of the Armenian Church, Galano attempts to prove that the Armenian and Latin Churches were united from Christianity's inception, but afterwards Armenians deviated from "true faith." In his attempt to correct the "errors" that the Armenian Church was accused of in a Medieval anti-Armenian source, Galano singled out the recitation of the Nicene Anathema to be a useful tradition to oppose the Arian heresy. ${ }^{137}$ Eremia likened the Nicene Anathema to one of the most important hymns or šarakan's of the period "O, marvelous patriarchs" dedicated to the 318 Fathers of the First Nicene Council. Originally at the end of this hymn the fourth- and fifth-centuries heresiarchs like Arius and Nestoruis are anathematized. In the confessional age the Council of Chalcedon, the Tome of Pope Leo I and the Catholic doctrine of Filioque were added to the text of anathema, the samples of which are preserved in many printed Hymnaries from the period. ${ }^{138}$

137 The Medieval source Clemente quoted is the Epistle of Pseudo-Isahak. This famous antiArmenian piece attributed to an unknown Armenian chalcedonic author was quoted by a number of Byzantine historiographers and polemists, such as Euthymius Zigabenus (d. 1118), Niketas Choniates (d. 1217), Nikephoros Ksanphopulos (Kallistos) (d. 1340) et. al., while composing chapters against the "Armenian heretics." For the originals, see Patrologia Graeca, vol. 132, ed. Jacques-Paul Migne, (Paris, 1864), 1154-1266. See also, Gérard Gartite, La Narratio de Rebus Armeniae: Edition Critique et Commentaire, Corpus Scriptorum Christianorum Orientalium, 132, Subsidia 4 (Louvain: Durbecq, 1967). See also Galano, Consiliationis, t. 2, pars 1, 36 .

138 The passage reads "Christ's martyr Saint Dioscoros disapproving of the unlawful Council (i.e. Chalcedon) anathematized Leo and his obscene Tome" «Ч.рцuju @phuunnuh

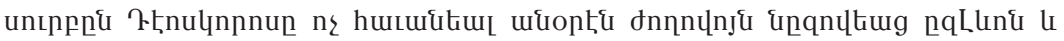

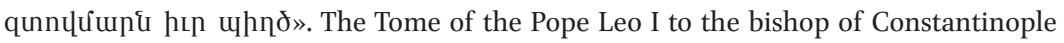
Flavianus about Eutyches became the basis for duophysite Christological formula adopted in the Council of Chalcedon, and has been continually rejected by the Armenian Church. See for instance, Šaraknoc' [Hymnary] (Amsterdam: Surb Ejmiacin and Surb Zōravar print, 1669-168o), 372-373, Šaraknoc‘ [Hymnary], (Constantinople: Astuacatur 
Eremia further argues that the recitation of the Anathema "As for those who say" should not be prohibited on the grounds that it was compiled in the fourth century and had lost its relevance. He pointed to the pan-Christian liturgical elements, contemporary with the Nicene Anathema, such as the renunciation of devil during the Baptism, the dismissal of catechumens before the Eucharist, and the doxology "Glory in the Highest" established in the first centuries of Christianity's history. ${ }^{139}$ Eremia was practical in his arguments: if those three ancient elements of Divine Office were complied with within the churches of all confessions, then the Nicene Anathema had the right to be recited in the Armenian Church, as the ancient unchangeable rule of prayer protected throughout centuries being the marker of confessional identity. According to Eremia, all the Catholicoi, including Suk'ias's patron Ełiazar Aynt'apec'i, had been reciting the Anathema. ${ }^{140}$

Eremia's polemics against Suk'ias succinctly illustrates the confessional dynamics of the Armenian communities of the late seventeenth century. He describes the populace as ignorant of doctrinal matters, hence, the social disciplining was possible mainly through practice and ritual. At the behest of his son vardapet Grigor, Eremia attempted a popularization of certain sermons by rendering them into Armeno-Turkish. Since 1679 he had rendered sermons about Transfiguration, Passion of Christ, the Virgin Mary, Holy Communion, et cetera. These sermons attempted to achieve fuller integration of the commoners into the doctrinal nuances preached from the stages of churches. ${ }^{141}$

According to Eremia, the populace would perceive whatever was preached by priests from the bemas of churches as the ultimate truth and could easily be led astray from the orthodox practice. The recitation of the creedal Anathema was an irreplaceable means for social disciplining; the commoners were periodically repeating the formula of the orthodoxy and listening to the refutation of the heresy even if they did not exactly understand its meaning. Armenian confession-building went hand in hand not only with Christian confessionalization, but also with Muslim "sunnitization" policies. In Christian milieu priests and pastors became powerful figures in internalization of the "true faith." Similarly, mosque preachers acquired great authority in Ottoman

Konstandnupōlsec'i Print, 1703), 447; Šaraknoc' [Hymnary], (Constantinople: Sargis Dpir Print, 1710-1711), 510.

BNF Arm. 334, f. 144r. It seems that the first two ritual components once actually compiled with in all Christian Churches were out of use in Catholic Church during the confessional age, while the doxology "Gloria" was sung only during the Tridentine Solemn Mass.

140 BNF Arm. 334, f. 146r.

141 See W408. Grigor K'ēōmiwrčean is the scribe of the manuscript. 
Muslim society as an instrument of the internalization of Sunni doctrine and practice formulated on the pages of 'ilm-i hăls ("state of faith"). ${ }^{142}$

Although 'ilm-i hâls had been designed to avert both doctrinal and behavioral deviations from the "pure path," the "heresy" could more likely be detected in practice. Likewise, from Eremia's point of view, the "heresy" on a demotic level, could occur only in practice: it might be found in the altered order of hymns, or in the altered position of hands (with arms spread or raised), in the way doxology was chanted (concordant or voice by voice), in covered or uncovered head. ${ }^{143}$ Practice was a touchstone for conversion; the severity of the Lent and the length of the Liturgy in the Armenian Church could steer the faithful toward more tolerable Roman Catholic rites. Eremia complains that in the minds of commoners the orthodoxy was measured per wealth and authority of a respective church. Thus, the Roman Catholic Church seemed more orthodox to wealthy Armenians: "Does not credibility of Easter belong to them, who possess so many kingdoms and wisdom?"144 With all his innate aptitude to peaceful cohabitation Eremia's approach was explicitly confessionalized: equalization to the "confessional others" through the facilitation of the rites was an unacceptable course for the Apostolic Church. The dividing line with other Christian confessions had to be drawn through the upholding of odd elements in traditions, such as Nicene Anathema.

It is unclear whether Eremia's arguments affected Suk'ias's further course of action. The absence of sources does not allow us to trace their future contact. All we know is that Eremia passed away shortly after composing his polemical piece, while a decade later Suk'ias sheltered Eremia's martyr-to-be brother Komitas K'ēōmiwrčean-a persecuted convert to Catholicism.

The seventeenth and eighteenth centuries marked the summit of the confessional age for the Armenians in the Ottoman and Safavid realms while Europe was long integrated into the process of confession-building stimulated by the emergence of Reformation and, consequently, counter-Reformation. Toward the end of the seventeenth century in the face of the rising influence of Tridentine Catholicism on the one hand and Protestantism on the other, the Armenian communities in Ottoman territories underwent confessional

\footnotetext{
142 See Terzioğlu, "Where 'Ilm-i hāls Meet Catechisms," 79-114.

143 BNF Arm. 334, f. 146v.

144 BNF Arm. 334, f. 147r.
} 
indoctrination. The time, when the mutually accepted practice of "good correspondence" shaped the relations between the Armenians and Catholics had ended. Now, the relationship within and between confessions was driven by the need to delineate the doctrinal borders of a respective Church. In the early 16oos, when Discalced Carmelites, Capuchins, Dominican Friars and Augustinian missionaries from Goa were preaching among Armenians of Safavid Persia, the cases of communicatio in sacris were allowed for both sides as the evidences of irenic acts and the articulation of Christians' unity in God. Decades later, however, with the intensification of Jesuit propaganda resulting in growing conversion of the Armenians to Catholicism, the incidents involving communicatio in sacris with the converts incited outrageous intracommunal debates in Constantinople. To address the issue, the Armenian Church authorities had to make attempts to redefine the boundaries of the Armenian orthodoxy and orthopraxy.

The political and territorial constrains became decisive factors in tackling the issue: having the spiritual center and head of the church — the Catholicos of All Armenians-in the territory of rival Safavid Persia, in Ejmiacin, the prelacies in Ottoman lands found themselves in a complicated situation when it came to the elaboration of new ecclesiastic policy. Though autonomous under the rule of Sultans, they formally depended on Ejmiacin's decisions not only in doctrinal matters, but also in Armenian Church politics, specifically with European countries and Roman Curia. The Catholicoi had to continuously dispatch their legates to the Ottoman Empire where their presence and demeanor had become the cause of constant discontent of Constantinople's social elite. The plan to establish an anti-Catholicosate or, more precisely, a new Catholicosate for the Western prelacies of the Armenian Church carried out by Eliazar Aynt'apec'i, was fueled with the desire to gain independence from Ejmiacin in decision-making and in acting accordingly with the Ottoman Empire's religious politics for its Christian subjects. On the other hand, it would jeopardize the integrity of the Armenian Apostolic Church and might lead to confessional assimilation, should Western prelacies happen to actually acknowledge the primacy of Rome. Therefore, when Eliazar Aynt'apec'i was elected the Catholicos of All Armenians in Ejmiacin, he still made attempts to keep a close watch on the doctrinal and behavioral deviations in the Constantinople community with the assistance of such go-betweens as Eremia and Suk'ias.

In fact, Eremia was the one reacting to the growing influence of Catholicism on the Armenian communities of the Ottoman Empire. With his late polemical pieces, he signaled the strong need in taking more explicit measures toward 
the redefinition of doctrinal boundaries of the Armenian Church and the enforcement of reshaped confessional norms. In contrast to the successful catechization of the Catholic and Protestant population in Europe and elsewhere, the Armenian Apostolic believers never became accustomed to catechisms, because of the absence of mechanisms for making them incumbent, and simply because of the insufficiency of the catechisms per se. The various "books of questions," produced in this period in both classical and colloquial languages, contained random questions and answers on variety of doctrinal, spiritual and moral topics, and could hardly be considered well-structured catechisms. ${ }^{145}$ Despite the strong tendency towards the appropriation of the new patterns of catechetic literature of the period, it would be a gross exaggeration to say that Armenians underwent intensified catechization in the seventeenth-century Ottoman Empire. The main channel for conveying the knowledge on "true faith" to the Apostolic flock remained sermons and rituals - where the Divine Liturgy, attended by the faithful every Sunday, occupied central place. Any actions at odds with ritual conformity, particularly the deviations from the canon of Divine Liturgy, were to be branded as "schismatic."

In the course of history, the non-Chalcedonic Armenian Church found itself in constant debates on orthodoxy with Chalcedonic Churches, propelling it to distinguish what it believed in from what it did not believe in. ${ }^{146}$ This in turn resulted in employment of both doctrinal affirmations and denunciations, that shaped the "true faith" of the Armenian Church, while their preservation grew into the integral part of the confession-building. The refashioning of the confessions could not be carried out through obliteration of the old elements of practice as a means of aligning with the confessional fashion of the period. Not only Eremia K'ēōmiwrčean, but also posterior apologists of the Armenian ecclesiastic tradition, saw the reshaping of the Apostolic faith from an "apocatastatic" perspective - that is to say from the point of view of the restoration to the original, early Christian doctrine, and the preservation of the Armenian Church practice in the very condition, which was inherited into the confessional age.

145 The catechetic material of the period is hitherto unexamined. I am working on the catechization paradigms that might have been applied to the Armenian communities in both Ottoman and Safavid Empires, but the outcome is still forthcoming.

146 For the role of anathema and renunciation in the creedal and baptismal formulas, see Pelikan, Credo, 189-195. 


\section{Appendix}

Manuscripts used:

Eremia K'ēōmiwrčean's polemical writing against Suk'ias Prusac'i survived in two manuscript copies-BNF Arm. 334 and W779. The scribe of W779 made calculations on the margins of his copy to detect the exact date of the writing. In his seminal book on Eremia K'ēōmiwrčean's biography Nersēs Akinian assumed it to be written in 1692. ${ }^{147}$

BNF Arm. 334, ff. 142r-148v

Collection. Date: 1697-176o. Place: Constantinople, church and college of Balat (ff. 113 and 148v); copyists: Komitas K'ēōmiwrčean (ff. 1-49) and anonymous scribes (1773, 1793, 1817); material: European paper; size: 16x20.5 cm; lines: 21/27; folios: 184; script: notrgir. $^{148}$

W779, ff. $1 \mathrm{r}-4 \mathrm{v}^{149}$

Collection. Date: 19th century. Place: unknown; copyist: unknown; material: paper; size: 27x20cm; lines: 33; folios: 335 ; script: notrgir. ${ }^{150}$

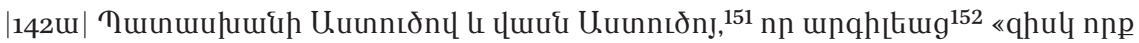

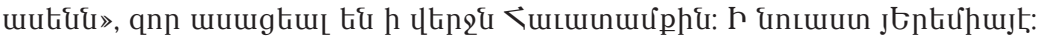

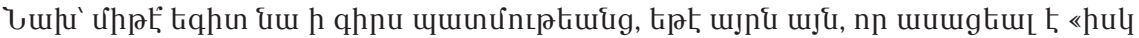

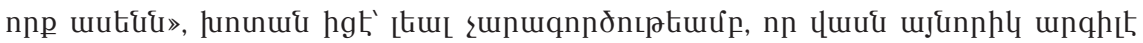

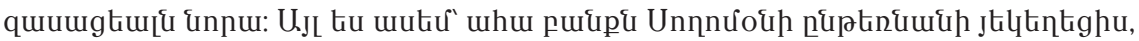

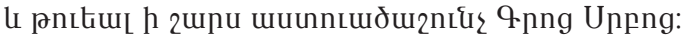

147 Nersēs Akinian, Eremia Č'èlēpi K'èomiwrčean: keank'n u matenagrakan gortsunēut'iwně [Eremia Ch'ēlēpi K'ēōmiwrčean: the Life and Literary Activity], (Vienna: Mekhitarist Press, 1933), 127.

148 For detailed description, see Manuscrits arméniens de la Bibliothèque nationale de France: Catalogue, 943-947.

149 I am thankful to Fathers Poghos Kodjanian and Simon Bayan of Mekhitarist Congragation in Vienna for their kind support in receiving the digital copy of this manuscript.

150 For detailed description, see Ts'uts'ak hayerēn dzeragrats' matenadranin Mkhitareants' $i$ Vienna [Catalogue of Armenian Manuscripts in Mekhitarist Library in Vienna], ed. Hamazasp Oskian, vol. 2, (Vienna: Mekhitarist Press, 1963), 329-330.

$151 \mathrm{~A}=\mathrm{BnF} 334$, ff. 142r-148v; B = W 779, ff. 1r-4v.

152 B unqtitiug 


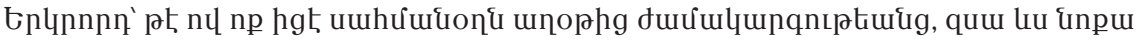

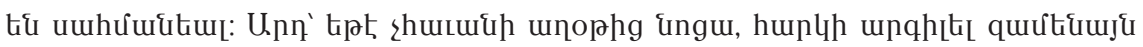

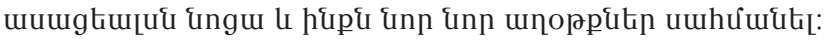

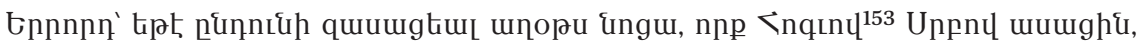

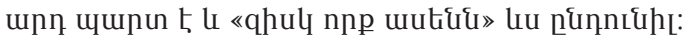

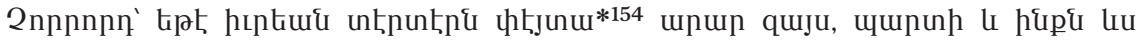

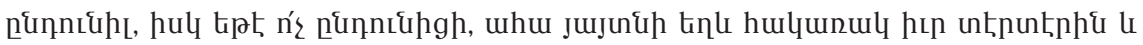
nuuntg々hu l dionhu:

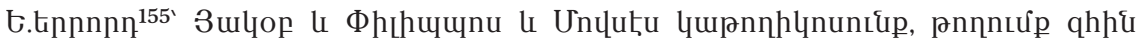

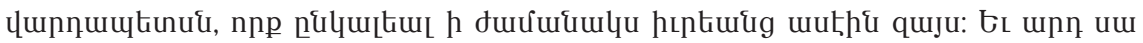

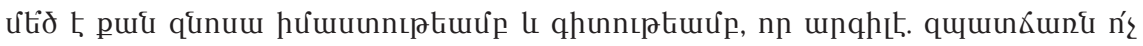
qhuntiup:

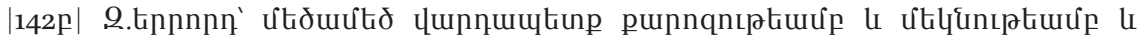

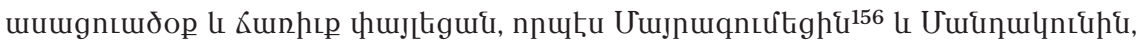

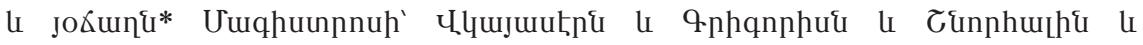

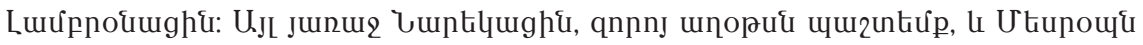

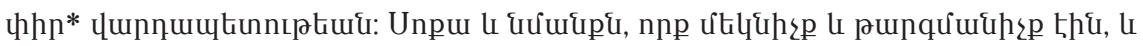

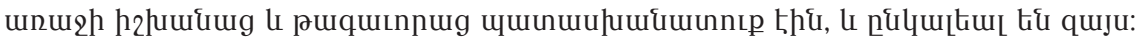

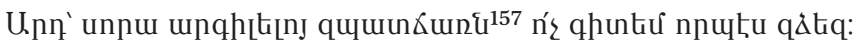

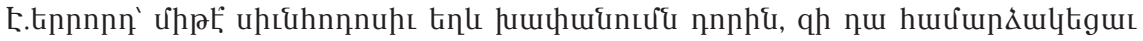

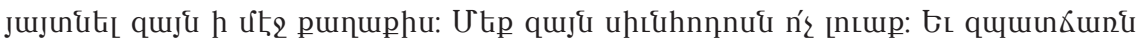

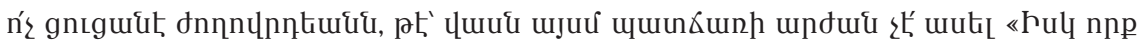
Uutư⿱亠:

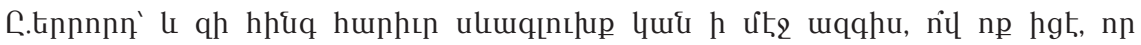

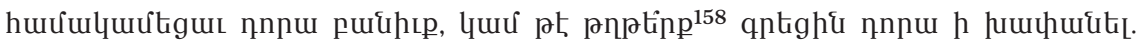
qúýt gnıggt útiq:

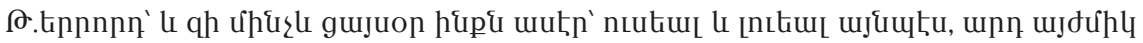

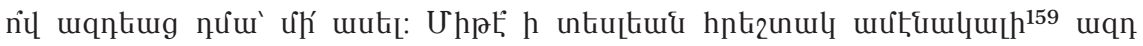

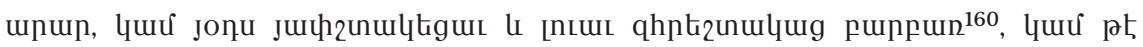

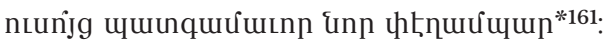

\footnotetext{
153 A hnqqny

154 For words marked with asterisks, see Glossary.

155 B hiqutinnnn

156 B ưujnuqnutighu

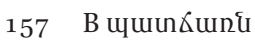

158 B рприц

159 B шưtiumum

160 B punpun

161 B thtnuúutn
} 


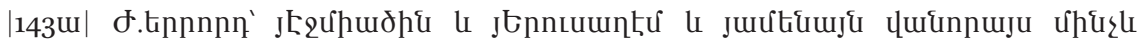

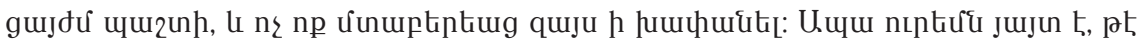

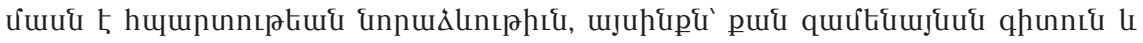

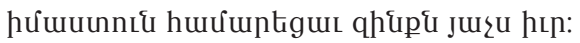

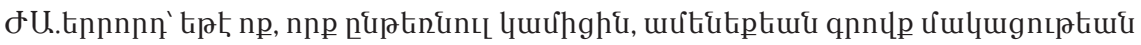

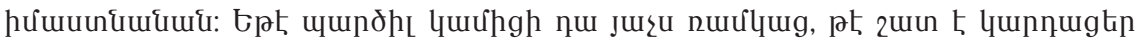

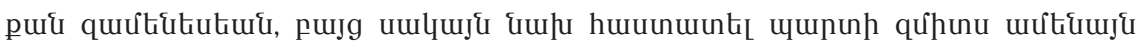

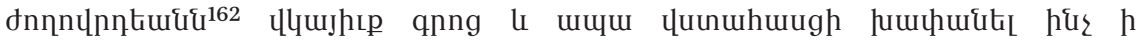

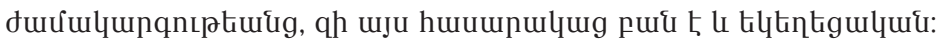

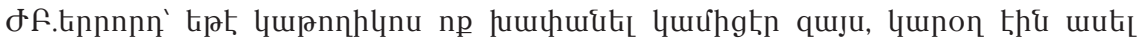

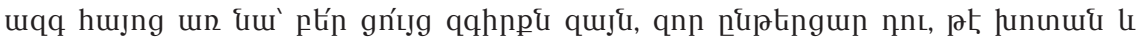

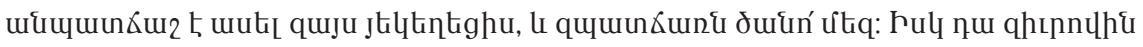

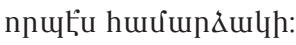

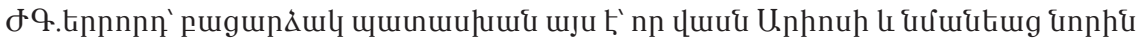

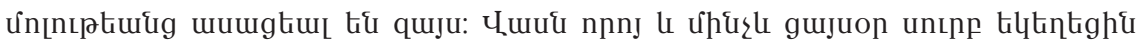

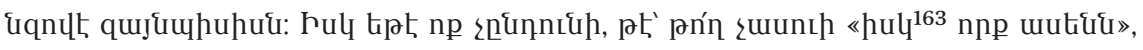

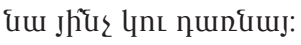

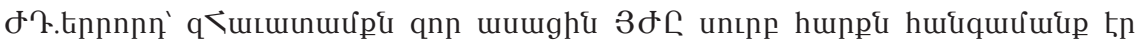

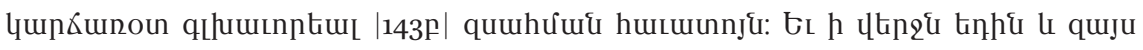

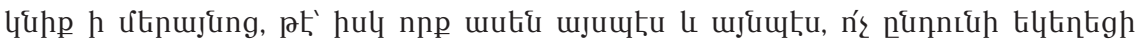

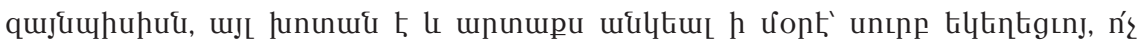

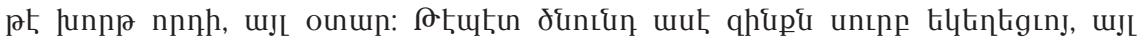

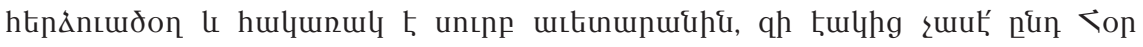

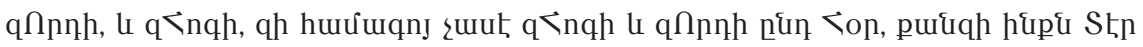

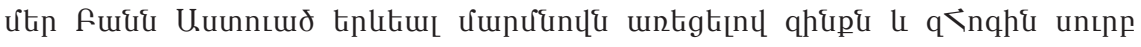

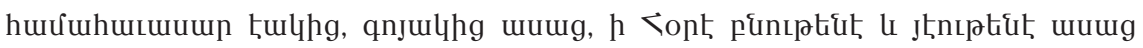

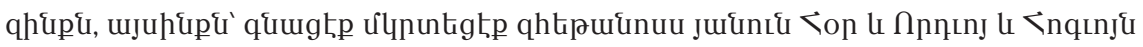

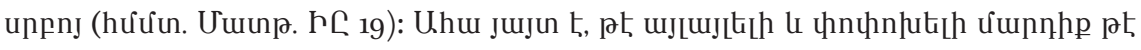

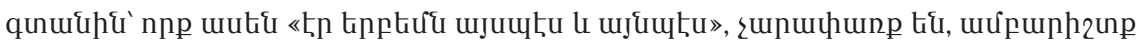

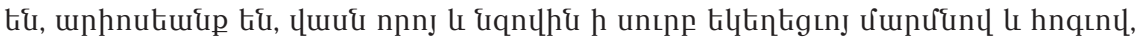

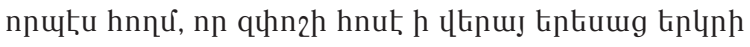

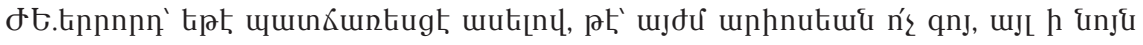

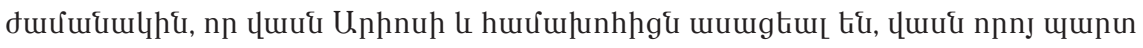

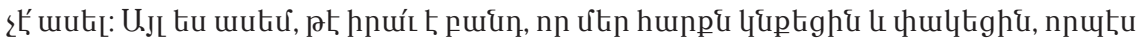

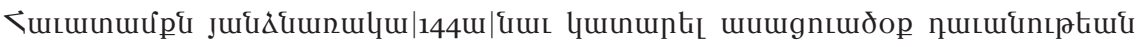

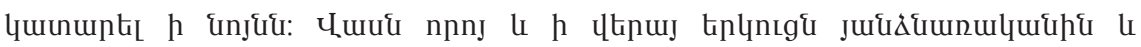

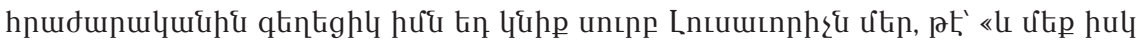

162 B dnnnunntiut

163 B hpl [ hul 


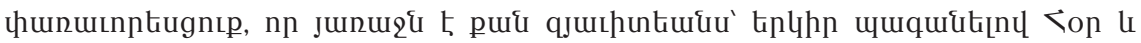

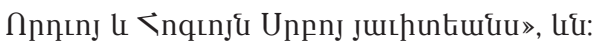

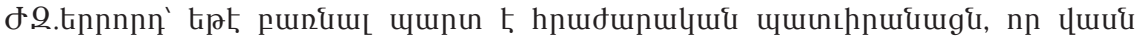

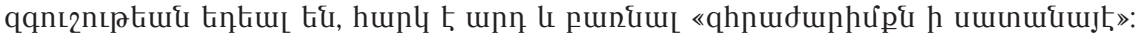

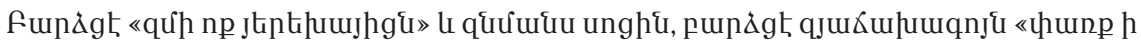

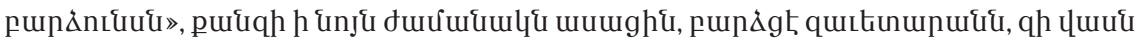

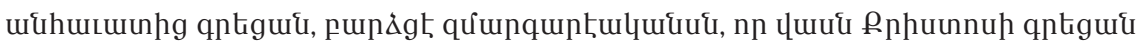

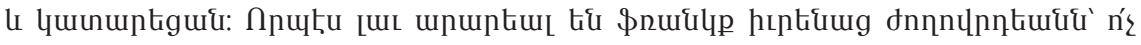

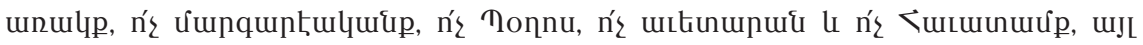

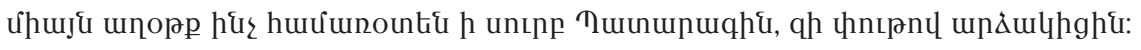

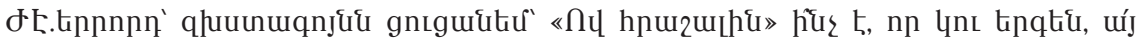

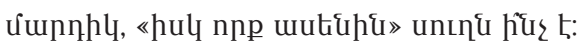

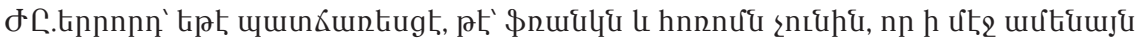

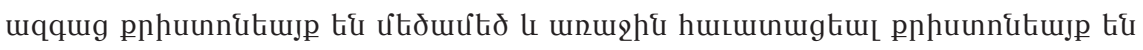

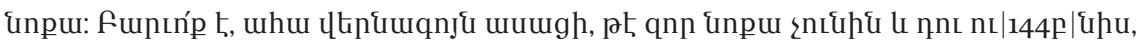

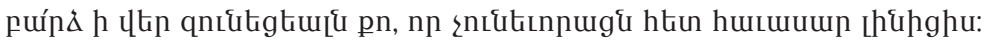

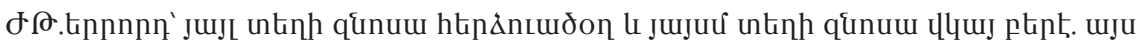
UJL ¿tinl:

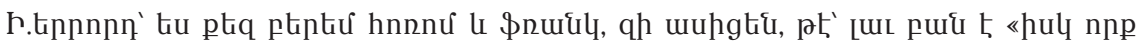

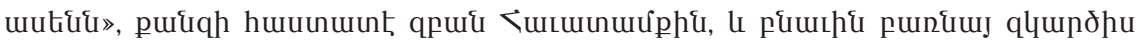

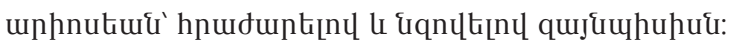

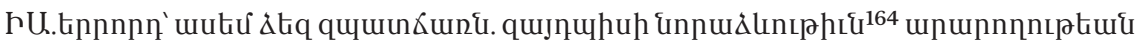

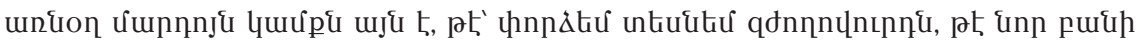

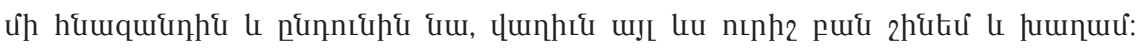

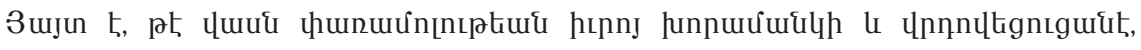

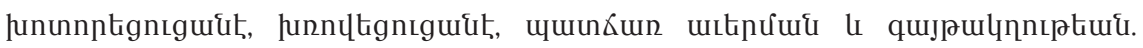
puhqhq* puhqhq, Łцutp* tцutp:

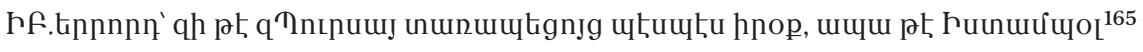

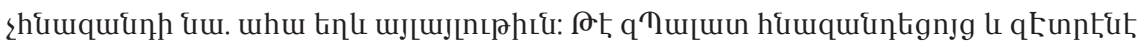

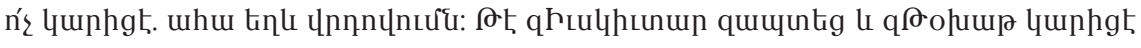

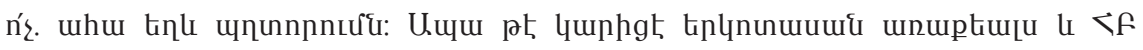

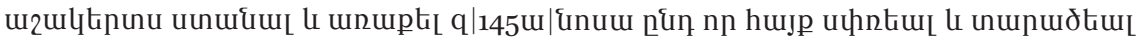

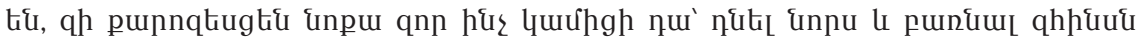

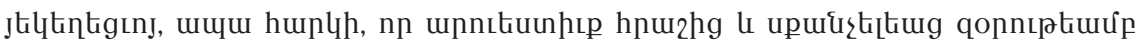

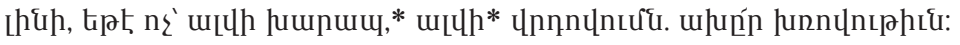

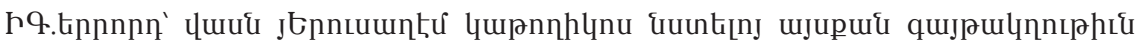

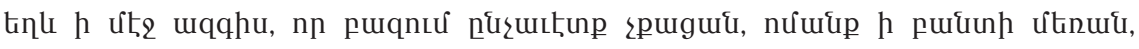

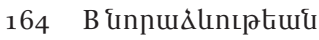

165 В 


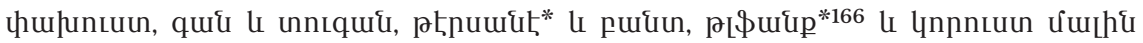

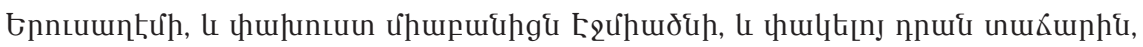

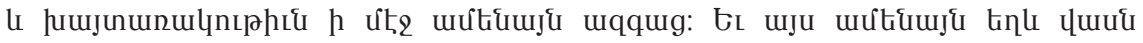

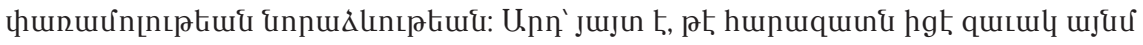

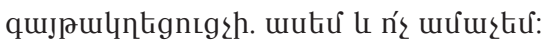

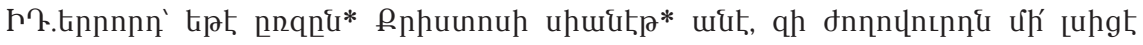

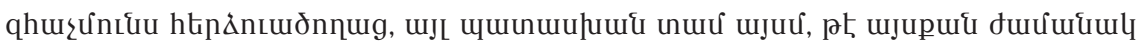

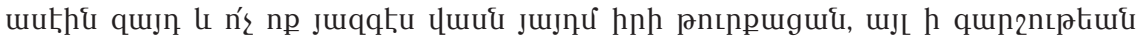

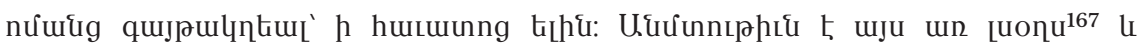

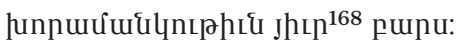

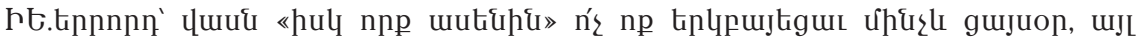

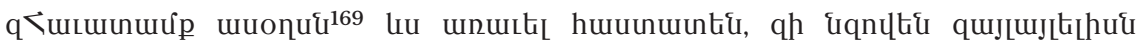

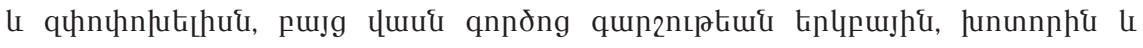

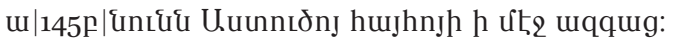

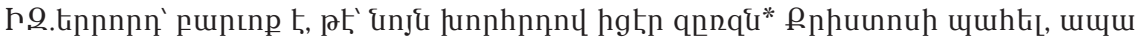

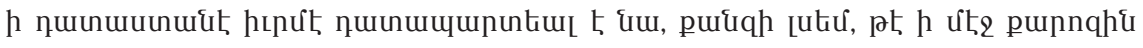

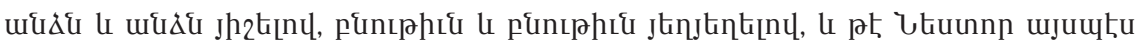

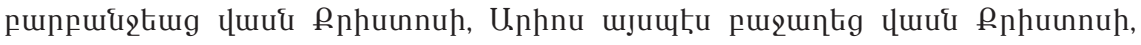

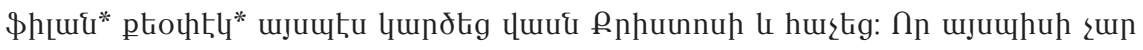

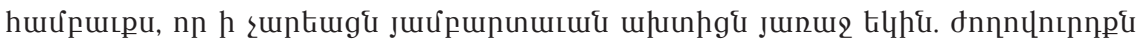

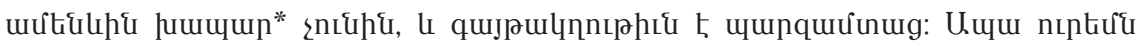

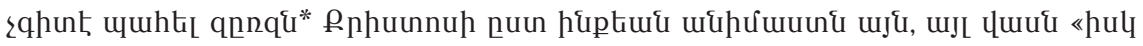

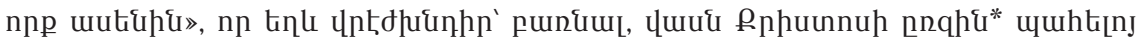

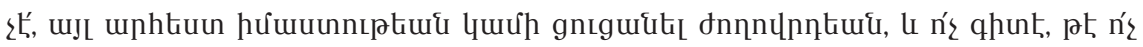

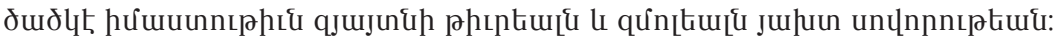

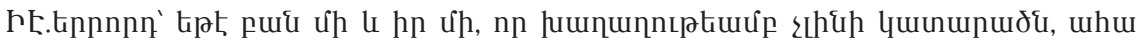

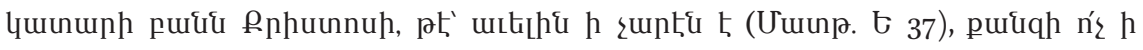

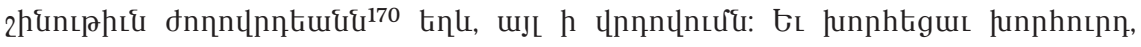

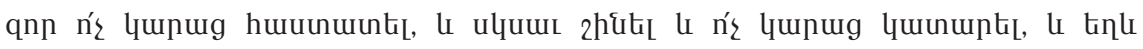

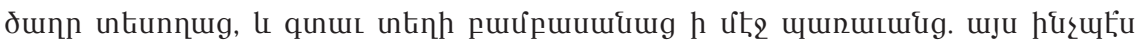

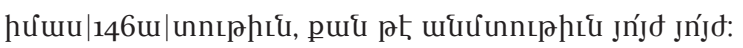

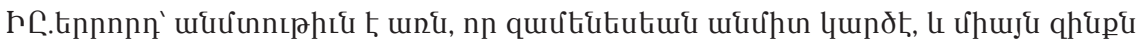

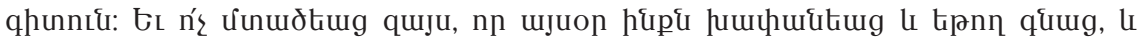

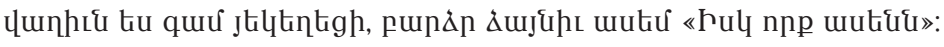

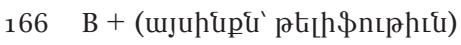

167 B Lunnu

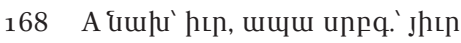

169 B uunnu氏

170 B onnulnntuut
} 


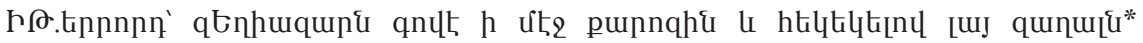

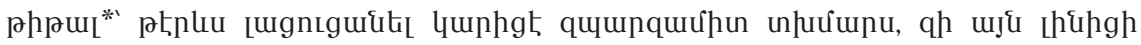

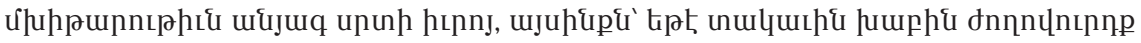

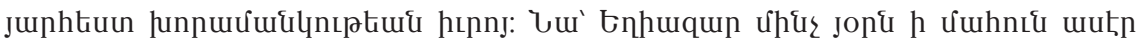

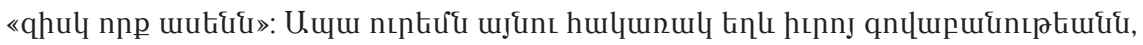

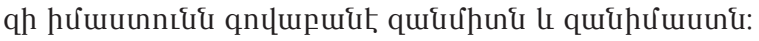

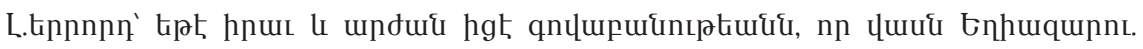

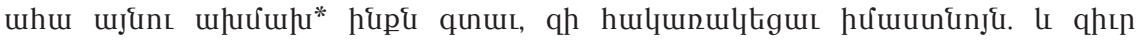

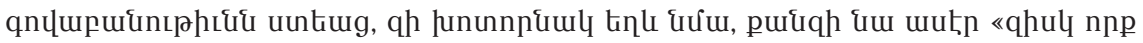
Uutitů:

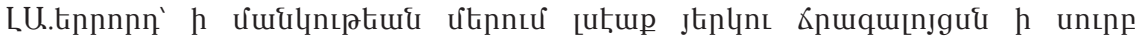

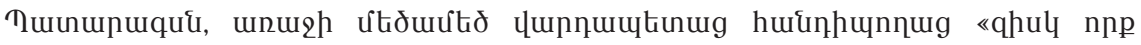

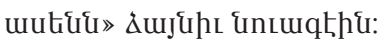

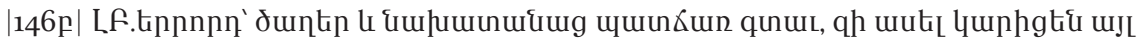

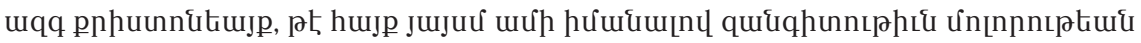

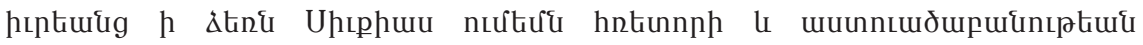

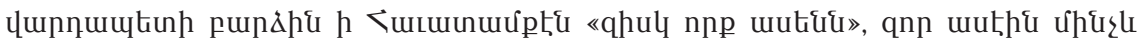

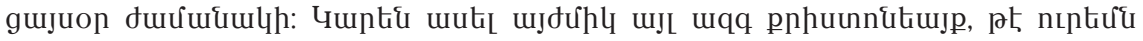

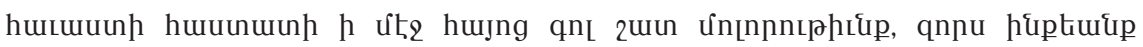

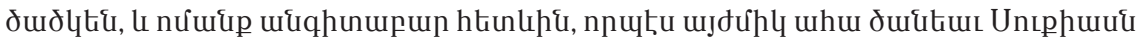

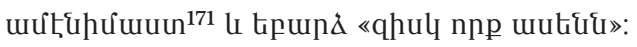

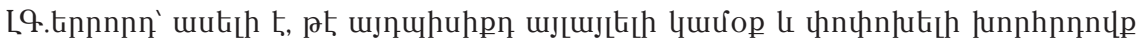
tiu, qh np ûtind

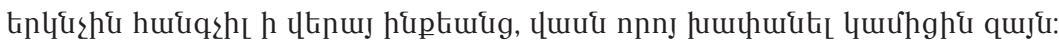

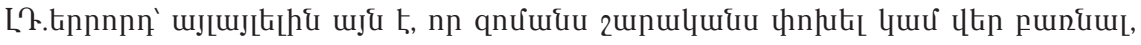

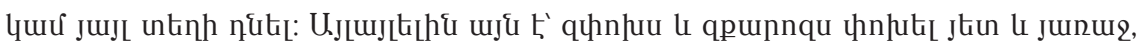

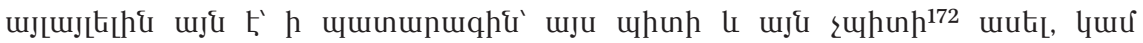

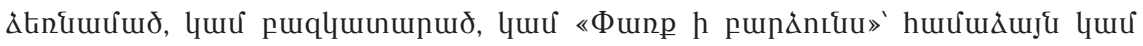

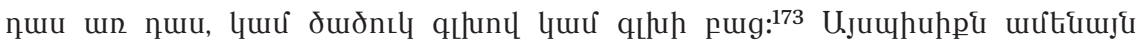

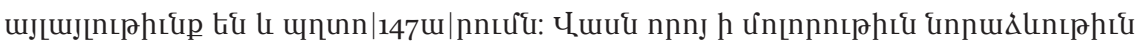

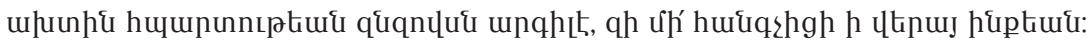

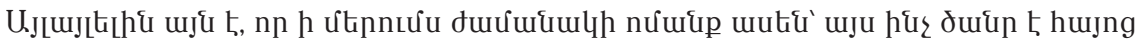

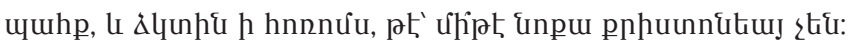

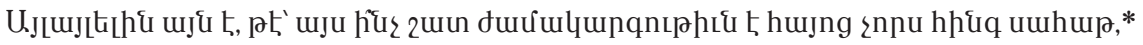

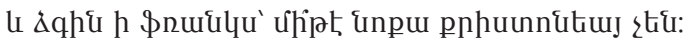

\footnotetext{
171 B ứtilipưuun

172 B \&huhun

173 B qLhuppug [ qLhup pug
} 


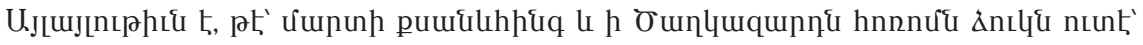

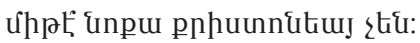

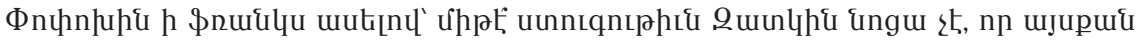

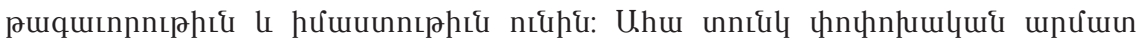

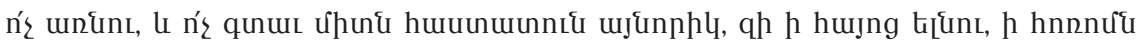

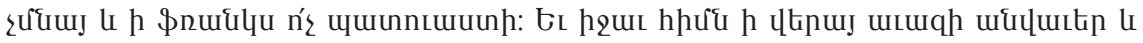

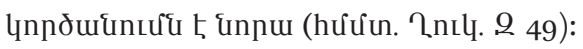

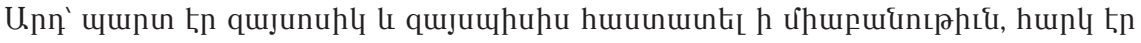

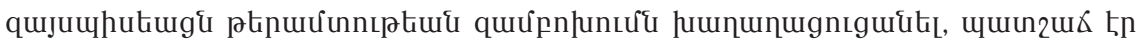

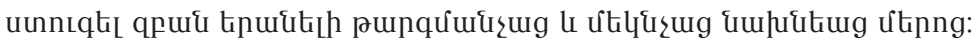

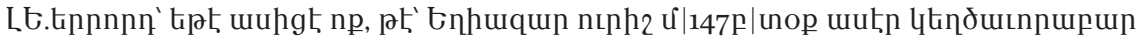

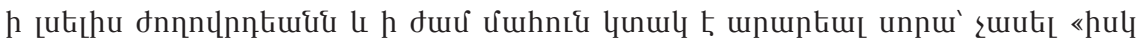

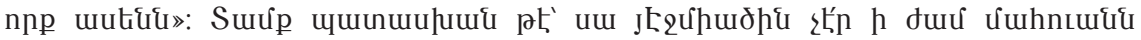

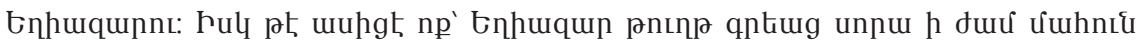

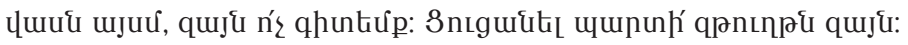

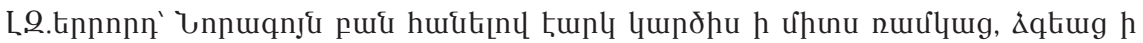

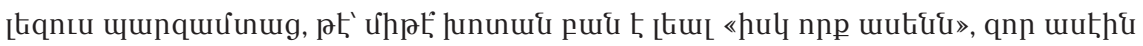
wiqhunupup uqqu utip:

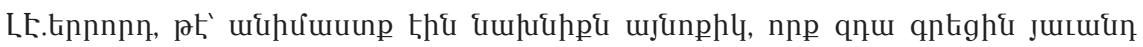

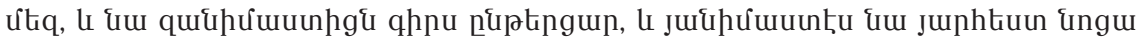
uphtiunpцpi hıрtiugg:

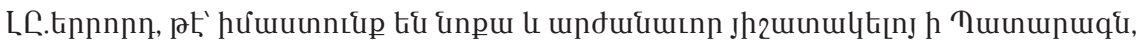

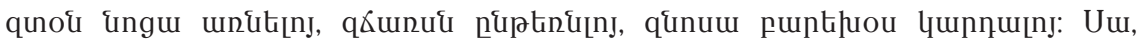

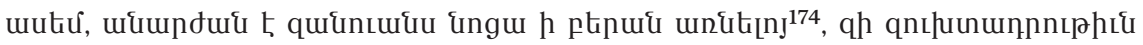

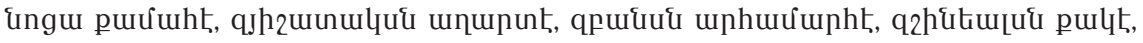

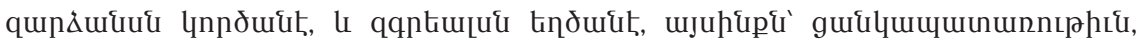

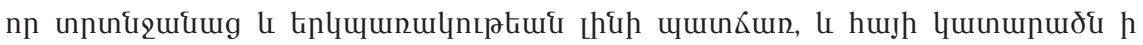

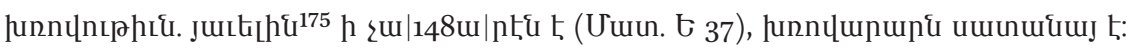

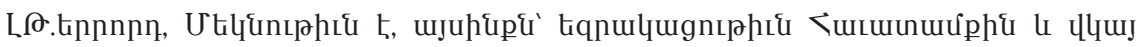

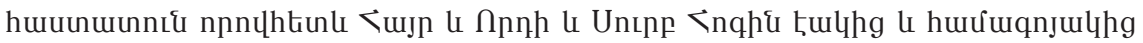

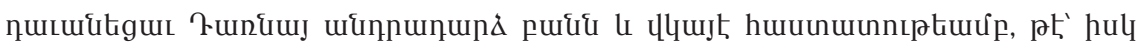

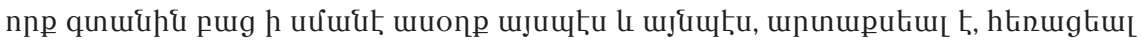

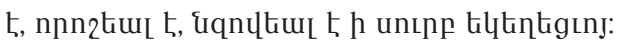

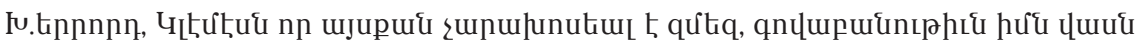

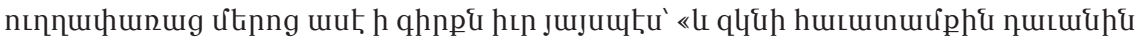

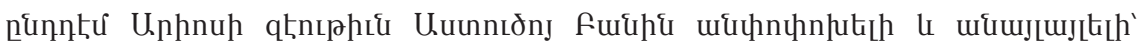

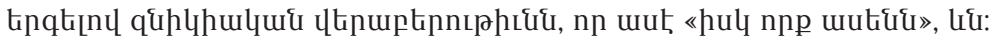

174 B unün

175 B wLtithi 


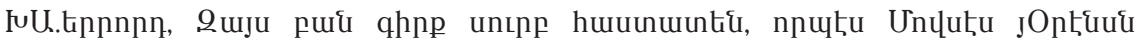

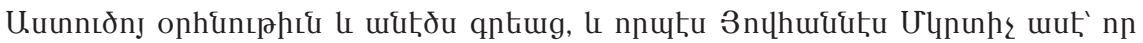

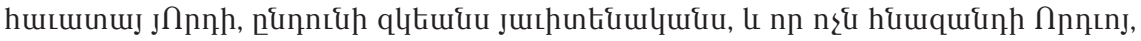

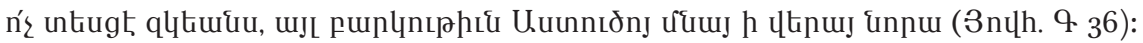

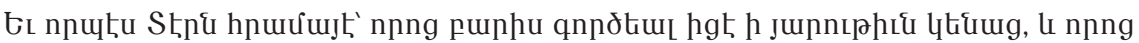

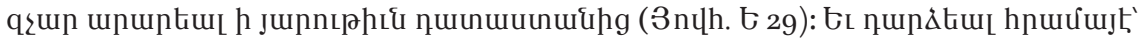

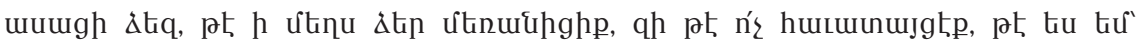

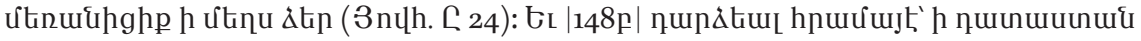

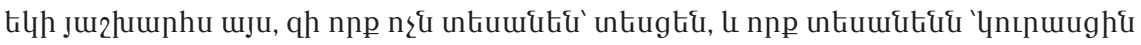

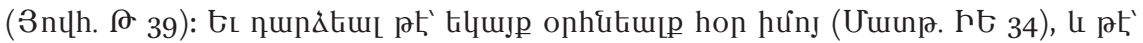

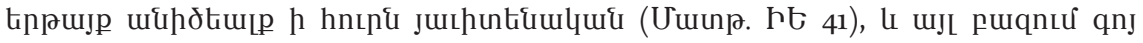

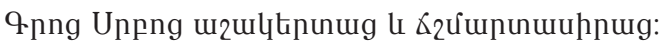

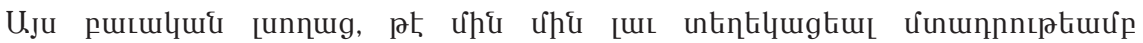

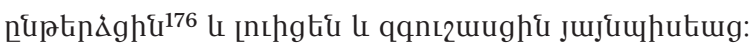

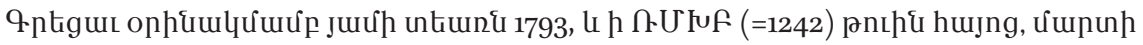

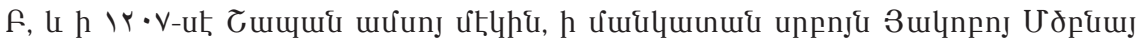

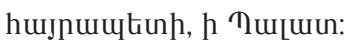

[The] response with God's help and concerning God [to the person] who disallowed [the recital of the anathema] "As for those who say"177 that is recited at the end of the Creed. [Narrated] by unworthy Eremia [K'ēōmiwrčean].

First, is it that he [i.e. Suk'ias Prusac'i] found in historical books, that the man, who established "As for those who say" is a useless person full of villainy, and because of that he [Suk'ias] disallows his words? But I say, behold the words of Solomon recited in churches and accepted among the Holy Scriptures. ${ }^{178}$

Second, those who established the prayers of [Liturgy of] Hours ${ }^{179}$ also established this [Anathema]. Thus, if he [Suk'ias] does not approve of their prayers, he is obliged to forbid all their sayings, and constitute new prayers of his own.

Third, if he accepts the prayers articulated by them through the Holy Spirit, hence, he is obliged to accept "As for those who say" as well.

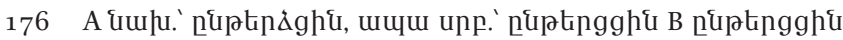

177 The incipit of the Nicene Anathema recited in the Armenian Church.

178 Eremia draws a parallel with the story of King Solomon, who turned to the pagan gods (1 Kings 11) towards the end of his life. His writings have remained canonical and recited in all Christian churches.

179 The Armenian text reads «dưuUlunqnıрһцi» (žamakargut'iwn), lit. order of Hours meaning the Divine Office of the Armenian Apostolic Church. 
Fourth, if his patron ${ }^{180}$ acknowledged ${ }^{181}$ this [Anathema], then he is obliged to accept it as well. But if he does not accept it, behold, he is revealed as opposing his patron and teacher and [spiritual] parent.

Fifth, the Catholicoi Yakob ${ }^{182}$ and P'ilipos ${ }^{183}$ and Movsēs, ${ }^{184}$ let alone the old vardapets, ${ }^{185}$ who accepted [it] at their times [and] had been reciting it. And now, is he greater than them in his wisdom and knowledge, to forbid [its recital]? I am unaware of the cause!

180 The Armenian text reads «unt,punt,p» (tērtēer), lit. a priest. Here it means a patron hierarch or a teacher. This is a reference to Ełiazar Aynt'apec'i, whose protégé was Suk'ias. The reference here is to his own father, Martiros K'ēōmiwrčean as to "my unțunțn (tērtēr)," lit. my priest. See K'ēōmiwrčean, Ōragrut'iwn, 192.

181 Armenian text reads «फhıunu unwn» (p'eyta arar). See Glossary.

182 Yakob IV J`ułayec'i (1598-1680) occupied the office of Catholicos in Ejmiacin from 1655 to 1680. He put a lot of effort to find support in Europe for the liberation of the Armenians from Persian rule. Eremia K'ēōmiwrčean was supporting Yakob J`ułayec'i's liberationist policy.

183 P'ilipos I Ałbakec'i (1593-1655) was Catholicos in Ejmiacin from 1633 to 1655 . Eremia K'êomiwrčean had personal acquaintance with this Catholicos. They first met in Constantinople, when Eremia was fifteen years old. Eremia's family too had an intimate acquaintance with Catholicos P'ilipos Ałbakec'i and accompanied him while he was in Constantinople between 1652-1653. P'ilipos appointed Eremia's father Martiros, a vicar of Holy Ejmiacin in Constantinople. Eremia admired the educational pursuits P'ilipos Ałbakec'i had engaged with, and devoted sentences to praise the latter in his Lament.

184 Movsēs III Tat'ewac'i (1578-1632) was Catholicos in Ejmiacin from 1629 to 1632 . A student of a prominent vardapet Srapion Urhayec'i, Movsēs managed to obtain a firman from Shah Abbas I for the renovation of the buildings in Ejmiacin two years prior to his official consecration as a Catholicos.

185 Armenian word «Lunnumbtin» (vardapet) stands for a celibate priest and is rendered as a teacher or doctor of theology. 
Sixth, such tremendous teachers as Mayragomec' $i{ }^{186}$ and Mandakuni, ${ }^{187}$ and the heir ${ }^{188}$ of Magistros ${ }^{189}$ — Vkayasēr, ${ }^{190}$ and Grigor, ${ }^{191}$ and Šnorhali, ${ }^{192}$ and Lambronac'i ${ }^{193}$ radiated through their sermons and commentaries, and sayings, and homilies. But first

186 Yovhan Mayragomec'i, also known as Mayrivanec'i $\left(570 / 5^{-6} 5^{2}\right)$, is an Armenian theologian and the prior of the monastery of Dvin. Yovhan spoke against the unity of the Byzantine and Armenian Churches, hence was accused of phantasism and was exiled during the tenure of pro-Chalcedonic Catholicos Nersēs Tayec'i. Excerpts from his theological writings have survived in the key florilegium of the Armenian Church Knik' hawatoy ("Seal of Faith").

187 Yovhan Mandakuni, who was an Armenian Catholicos, a canonist and hymnologist in the second half of the fifth century, who established a new group of ecclesiastical canons enclosed in the Book of Canons of the Armenian Church. The majority of important canons refer to the observance of fasts and the Great Lent.

188 The Armenian text reads «joðun» (yocat). See Glossary.

189 Grigor Magistros Pahlavuni (ca. 990-1058) is the Duke of Mesopotamia, the governor of Edessa, a laymen scholar, who descended from the princely Pahlavuni family. Magistros is famous for his letters written to various high-rank ecclesiastical figures on different doctrinal and disciplinary issues, which challenged both the Armenian and Syrian Orthodox Churches.

190 Grigor Vkayasēr (Gregory Martyrofile) d. 1105, the son of Grigor Magistros Pahlavuni, occupied the office of the Catholicos in Hromkla (Rumkale) between 1066-1085 during the Armenian Cilician period. He is also the founder of the Armenian Pahlavuni dynasty of Catholicoi and earned the sobriquet Martyrofile for commissioning translations of martyrdoms and lives of saints from Greek into Armenian.

191 Grigor III Pahlavuni (d. 1166) was elected as Armenian Catholicos at the age of twenty. During his tenure, the Catholicosate was relocated to Cop'k', later to Hromkla (Rumkale). He was the first Catholicos to start a dialogue with the Latin Church on doctrinal differences. Grigor Pahlavuni was known for penning a number of hymns, canticles, poems, and translating martyrdoms.

192 Nersēs IV Šnorhali (d. 1173) Armenian Catholicos in Hromkla (Rumkale). The greatgrandchild of Grigor Magistros and the brother of Catholicos Grigor Vkayasēr. Šnorhali was engaged in the discourse for the union of the Byzantine and Armenian Churches initiated by the Greek Emperor Manuel I Komnenos (1118-1180). The negotiations were interrupted with the death of the Emperor. Both the Armenian Apostolics and Armenian Catholics referred to Nersēs Šnorhali as to an "orthodox." Clemente Galano, who translated Šnorhali's conversations with the Greek philosopher Theorianus into Latin and Armenian-illustrates Nersēs Šnorhali as an admirer of the Chalcedon formulas. Šnorhali's book Jesus the Son, printed in underground Catholic printing press in Constantinople, was banned by vekil Yovhannes Izmirc'i in 1703 .

193 Nersēs Lambronac'i (d. 1198) is a theologian, translator and a courtier descending from the Hetumid and Pahlavuni royal dynasties in Cilicia. Lambronac'i was accused by Eastern vardapets of adhering to the doctrine of the Latin Church. 
of all [come] Narekac'i ${ }^{194}$ whose prayers we admire and Mesrop, ${ }^{195}$ the pinnacle ${ }^{196}$ of the doctrine. They and their equals - the commentators and interpreters [of the faith], who took the responsibility before the princes and kings, accepted it. Hence, just like you, I am also unaware of his judgment to forbid [its recital].

Seventh, is it that through a Synod, the abolition of this [Anathema] occurred, so that he dared proclaim it in the city? We have not heard of that Synod! And he does not reveal the cause to the public, [to prove], that due to this very reason, it is not of consequence to recite "As for those who say."

Eighth, and there are five hundred clerics ${ }^{197}$ among our nation. Which one of them accorded with him in their words? Or perhaps they scribbled letters to him to abolish [recitation]? Let him show it to us!

Ninth, and he has been hitherto reciting it himself as he learned and heard in this manner. So, now who influenced him not to recite [this]? Is it possible, that the angel of the Almighty manifested through a vision, ${ }^{198}$ or perhaps he ascended to the havens and heard the angelic tongues, ${ }^{199}$ or perhaps a messenger [and] new prophet ${ }^{200}$ taught [it to him]?

Tenth, it has been observed in Ejmiacin and Jerusalem and all the monasteries to this day, and no one has made up his mind to abolish it. Hence, it is obvious that [this] innovation is part of [his] arrogance, that is to say, he imagined himself more knowledgeable and wiser than all others.

Eleventh, that the ones, who are willing to read [it]; they all become wise [by means of] all writings of erudition. If he desires to boast to the peasants that he has read more than the others, first he has to prove it in public with the testimonies from the writings, and then take the confidence to abolish anything from the Hours, ${ }^{201}$ since that is a public matter, as well as ecclesiastical.

194 Grigor Narekac'i (d. 1003) is an author of paramount importance: a monk, a mystical poet, a theologian and a Universal doctor of the Church famous for his renowned Book of Lamentation, which has been translated into many languages.

195 Mesrop Maštoc' (ca. 362-440) is a theologian, translator, author of numerous hymns and the inventor of the Armenian alphabet. He collaborated with Armenian Catholicos Sahak I Part'ew (348-439) and king Vṛamšapuh (Bahram-Shapuh) (ca. 389/40o-414) in promoting Armenian Christian identity and the appropriation of Christian culture across Armenia.

196 The Armenian text reads « $\mathrm{h} h \mathrm{n} »\left(p^{\text {ir }}\right.$ ). See Glossary.

197 The Armenian text reads «ulumq[nılup» (sevagluxk), lit. blackheads, a calque from Turkish karabaş. This name was applied to the Armenian Apostolic monks because of their black hoods worn together with black cassocks.

198 Allusion to the visions in the Old Testament.

199 Allusion to Paul's vision in 2 Corinthians 12:1-7.

200 Allusion to the vision of Muhammad in Islamic tradition.

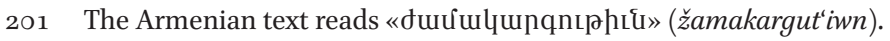


Twelfth, if any Catholicos would wish to abolish this, the Armenian people could tell him, "Bring and show [us] the book you read, [which says] that reciting this in the church is useless and improper! Also acquaint us with the cause!" So, how dares he [abolish it] himself?

Thirteenth, the perfect answer is that it has been articulated in consequence of the vice of Arius and his equals. Therefore, the Holy Church anathematizes them hitherto. And if one does not accept it [by saying], "Let "As for those who say" not be recited," then who will he turn into?

Fourteenth, the $\mathrm{Creed},{ }^{202}$ articulated by 318 Holy Fathers, ${ }^{203}$ was a way to succinctly enclose the definition of faith. And at the end of it [the Creed] they put this seal of ours, so that those who say so and so, are not accepted by the Church, and that he [Arius] is worthless and external to the mother, [that is the] Holy Church-not [as] a stepson, but an alien. Although he [Arius] claims himself to be begotten of the Church, he is a heretic and adversary of the Holy Gospel, since he does not confess the Son and the Holy Spirit [to be] of the very same nature with the Father, and does not confess the Spirit and the Son consubstantial ${ }^{204}$ with the Father. For our Lord Word of God, while revealing himself incarnated, proclaimed himself coequal, consubstantial, [and] coessential with the Holy Spirit, proclaimed himself of the very nature and the very essence with the Father, that is "Go, baptize all the nations in the name of the Father, and the Son, and the Holy Spirit" (cf. Math. 28:19). Thus, it makes clear, that if there appear alterable and mutable people, who say "There was a time" 205 and so forth; they will be [considered] heretics, ${ }^{206}$ infidels, Arians. Hence, [the like of them] are anathematized with body and soul, by the Holy Church, resembling the wind that disperses the dust on the surface of the world.

Fifteenth, if he [Suk'ias] argues that there are no Arians nowadays, but [since] this was articulated against Arius and his partisans at one time, therefore it is of no consequence to recite [it any more]. Yet I say, your word[s] are true indeed, that our Fathers sealed [this] up, and confined [it] to be observed the same way as the Creed is observed

202 The Armenian text reads «रutunuúp» (Hawatamk'), lit. we confess.

203 The reference here is to the 318 hierarchs participating in the Council of Nicaea in 325 that constituted the Nicene Creed.

204 The Armenian text reads «hưưqn nun 〈op» (hamagoy and Hōr), a calque from Greek

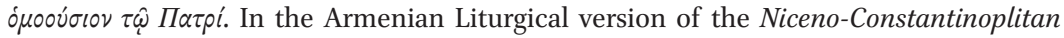
Creed, the term «huúuqnj» (hamagoy), which is Greek ópoov́ros and Latin consubstantialis, is not used. Instead, there stands «unju hupu h punıptiut <op» (noyn ink'n $i$ bnut'enē Hōr), meaning "of the very same nature of the Father" or "of one essence with the Father."

205 A reference to the text of the Nicene Anathema.

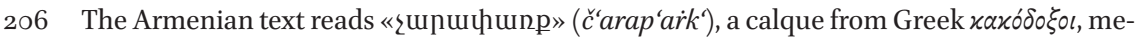
naing "the ones having wrong doctrine." 
through affirmation of the words of faith. Because of that, our Saint Lusaworič ${ }^{\text {‘207 }}$ put a beautiful seal upon both the affirmation and renunciation, that is "As for us, we shall glorify Him who was before the ages, worshipping ... the Father and the Son and the Holy Spirit, now and always and unto the ages of ages" and so forth.

Sixteenth, if the renunciations, which were established for the good of the cautious, are to be abolished, then the "We renounce Satan" 208 is to be abolished as well. Let "Let none of the catechumens" 209 and suchlike be abolished; let the frequent "Glory in the Highest" 210 be abolished, as it was composed in the same period; let the Gospels be abolished, as they were composed for infidels, let the Prophets be abolished, that were

207 Grigor Lusaworič (Gregory the Illuminator) is the founder of the Armenian Church as an institution in the early fourth century.

208 Renunciation of the devil is an ancient baptismal practice of the Church, first witnessed by Tertullian. See Jaroslav Pelikan, Credo, 191. In the Armenian Church it reads as follows: "We renounce Satan and his every deceit, his wiles, his deliberations, his course, his evil will, his evil angels, his evil ministers, his evil agents, and his every power renouncing, we renounce." See Frederic C. Conybeare, Rituale Armenorum being the Administration of the Sacraments and the Breviary Rites of the Armenian Church, (Oxford: Clarendon Press, 1995), 86-108; Mesrob Tashjian, "The Sacrament of Holy Baptism in the Armenian Apostolic Church" in Baptism Today: Understanding, Practice, Ecumenical Implications, ed. Thomas F. Best, (Collegeville, Minnesota: Liturgical Press, 2008), 17. All Christian churches preserved the renunciation of the devil one way or another: the variant of this formula occurs in the office of catechumens in the Eastern Orthodox Church ("Do you renounce Satan and all his works and all his worship and all his angels and all his pomp?"), but not in baptismal rite. Its usage appears in the old Gallican Rite of the Western Church ("Do you renounce Satan, the pomps of the world and its pleasures?"). Renunciation of the devil is accepted also in the Roman Catholic, Syriac Orthodox, Coptic and Ethiopic rites. See Henry A. Kelly, The Devil at Baptism: Ritual, Theology, and Drama, (Wipf and Stock Publishers, 2004), 104; Walter Caspari, "Renunciation of the Devil in Baptismal Rite," in The New Schaff-Herzog Encyclopaedia of Religious Knowledge, ed. Samuel M. Jackson et al., vol. 9, (New York and London, 1911), 488-489.

209 The dismissal of catechumens was and still remains though nominally, part of the Divine Liturgy in Christian churches. It made an appearance in the forth-fifth centuries in John Chrysostom's Liturgy, when the catechumens were ordered to leave the nave after the Liturgy of the Word and to not approach the Holy Communion. The first part of the Divine Liturgy is also called the Liturgy of Catechumens. In the Divine Liturgy of the Armenian Church it is pronounced as follows: "Let none of the catechumens, none of little faith and none of the penitents or the unclean draw near this divine mystery!" See The Divine Liturgy of the Armenian Church, 23.

210 "Glory in the Highest" (Gloria in Excelsis) is part of the Divine Office for all Christian churches established from the forth century on. Its variants had been chanted during Matins in the Armenian Apostolic and Eastern Orthodox Churches, as well as the Assyrian Church of East. It is chanted in the Roman Catholic Church during the Tridentine Holy

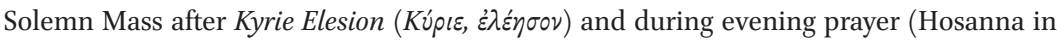
the Highest) in the Syriac Orthodox Church, it is chanted during the Coptic Liturgy of Saint Basil within the Prayer of Reconciliation. See Conybeare, 134, 385, 456. 
written and fulfilled for Christ. How commodious Franks ${ }^{211}$ made it for their peopleno Proverbs, no Prophets, no Paul, ${ }^{212}$ no Gospels, no Creed: only some brief prayers during the Holy Mass in order to dismiss [people] rapidly. ${ }^{213}$

Seventeenth, I strictly declare: Oh, people! What is "O, marvelous!"214 that is sung [during the Liturgy]? [And] what is the deficiency of "As for those who say" [so that not to be recited]?

Eighteenth, that he [Suk'ias] argues that the Franks and the Greeks, who are the greatest, and the first Christians among all nations, do not have this [Anathema]. That is correct. Behold, like I said earlier, if they do not have it and you do, should you abolish what you have to become equal with those who do not?

Nineteenth, on other occasions he refers to them [Franks and Greeks] as schismatics, whereas here he refers to them as testifiers. This will not do either!

Twentieth, I can show you Greek[s] and Frank[s], who will say that "As for those who say" is a good thing, since it affirms the words in the Creed and effaces entirely the Arian conjectures by renouncing and anathematizing the likes [of Arius].

Twenty-first, I tell you the cause. The will of a man putting into practice such an innovation is to test people to see if they obey and accept it, [then] tomorrow I will invent something else and execute. It is obvious, that for the sake of his vanity, he dissembles and disquiets, misleads and perplexes people, [becomes] the cause of destruction and dismay; that's for sure; ${ }^{215}$ that's for certain. ${ }^{216}$

Twenty-second, for if he managed to torment Bursa ${ }^{217}$ with various things, but Istanbul would not obey him-behold, there will be distortion. If he managed to

211 The Armenian text reads «\$nuulp» $($ frank $k$ ), meaning Roman Catholics, at times French or Europeans in general.

212 A reference to the Epistles of Paul.

213 Apparently Eremia's words refer to the Roman Catholic Low Mass.

214 One of the hymns in the Canon of Holy Patriarchs in the Armenian Hymnal (Šaraknoč). "O, marvelous patriarchs" refers to 318 Church Fathers partaking in Nicene Council of 325, which contains an anathema against Arius.

215 The Armenian text reads «puhqhq puhqhq» (t'ahgig-t'ahgig). See Glossary.

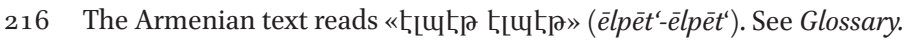

217 Bursa or Prusa, a city in the northwestern Turkey, used to be an Ottoman capital in the fourteenth century. Before the Armenian Genocide of 1915, there were more than seventeen Armenian churches in Bursa and neighborhood, the most famous of which were the churches of the Holy Mother of God (Surb Astuacacin) and the Holy Archangels (Surb Hreštakapetac'). 
subjugate Balat, ${ }^{218}$ but could not [succeed in] Edirne ${ }^{219}$ — behold, there will be disorder. If he managed to habituate Üsküdar, ${ }^{220}$ but could not [succeed in] Tokat—behold, there will be disturbance. Then, if he is capable of acquiring twelve apostles along with seventy-two disciples and forwarding them to where the Armenians are scattered and spread, for they will preach whatever he desires - establishing new and abolishing the old [customs] of the Church, then it is to happen through the thaumaturgy and the power of wonderworking. If not, [then there will be] more destruction, [there will be] more disquietude. But is that not a turmoil!?

Twenty-third, there was such a grand scandal among our nation because of [the establishment of] Catholicosal throne in Jerusalem. ${ }^{221}$ A number of opulent [people] eliminated, some died in prison. Escape, torment and indemnity, galley ${ }^{222}$ and jail, fatigue and loss of the animals of Jerusalem, and escape of the monks of Ejmiacin, and closure of the door of the monastery, ${ }^{223}$ and disgrace among all the nations [occurred].

218 Balat or Palat is a quarter in Constantinople, on the western bank of Golden Horn. Traveling to Constantinople in 16o8, Simēon Lehac'i described Saint Nikolayos (Surb Nikotayos) church of Balat, shared by the Armenians and Franks, where each served their own service in "love and peace." Balat also housed the Holy Archangels Armenian church. According to the seventeenth-century Armenian chronicler Grigor Daranałc'i, the Holy Archangels was an abandoned Greek church in the Jewish neighborhood of Balat. Thanks to Aristakēs Xarberdc'i, the Armenians obtained a firman from Topal Recep Pasha (d. 1632) to attain the church.

219 Edirne, a city in northwestern Turkey, was the third Ottoman capital before Constantinople. Before the Armenian Genocide of 1915, it housed three Armenian churches-Saint Gregory the Illuminator (Surb Grigor Lusaworič), Saint Toros (Surb T'oros) and Saint Karapet (Surb Karapet).

220 Üsküdar or Scutari, a district of Constantinople on the shore of Bosphorus is one of the three districts outside the city walls during the Ottoman period. The Holy Cross (Surb $\left.X a c^{`}\right)$ Armenian church is in Üsküdar.

221 Eremia refers to the turmoil in Jerusalem instigated by Etiazar Aynt'apec'i when he established an anti-Catholicosate there.

222 The Armenian text reads «ptpuuit» (t'érsanē). See Glossary.

223 Eremia alludes to the closure of the doors of Saints James Convent in Jerusalem. In 1656, the tensions between the Greeks and Armenians over the sites in the Holy Land reached their peak. When the Greeks managed to obtain a firman from grand vizier allowing them to appropriate the Saints James Convent of Armenians. Ełiazar, then the deputy of the Armenian Patriarch of Jerusalem, appealed to the ruler of Damascus Teyar Oğlu to tackle the issue. Having already been bribed by the Greeks, the ruler promised to find a solution commanding Eliazar to hand in the keys of the Convent to him until the problem was solved. In the face of his apprehension, Ełiazar entrusted the keys to Teyar Oğlu, who kept the Convent doors locked and sealed till 1657, when the Greeks took it over. The Convent was returned to the Armenians in 1659 . 
And all these on behalf of the vanity of innovation. Thus, it is obvious, that he [Suk'ias] is the genuine child of that scandalous man. ${ }^{224}$ I claim [this] and I am not ashamed!

Twenty-forth, if he wants to defend ${ }^{225}$ the honor ${ }^{226}$ of Christ in order for people to refrain from hearing the bark of the heretics, then I reply to this-for such a long time it has been recited and no one from our nation turned Turk, ${ }^{227}$ but rather they betrayed their faith tempted by the abhorrence of certain people. This is bêtise for the listeners and artifice in his course.

Twenty-fifth, to this day no one was misled because of "As for those who say." Moreover, those, who recite the Creed, rather affirm that they anathematize mutable and changeable ones. But because of the deeds of abhorrence, they got perplexed and were led astray, and the name of the God is blasphemed among the nations.

Twenty-sixth, it is good, if with the very same intention, the honor ${ }^{228}$ of Christ was defended; yet he is condemned with his own judgment, for I hear him recalling the person and person ${ }^{229}$ during the sermon and reiterating nature and nature, ${ }^{230}$ and [telling] that Nestorius trifled in such-and-such manner about Christ, and Arius prattled so-and-so about Christ, and the such-and-such ${ }^{231} \mathrm{dog}^{232}$ assumed so-and-so about Christ and barked. People are entirely ignorant, ${ }^{233}$ that this kind of wicked reputation had emerged from malicious and haughty disease; hence, that is a temptation for the simple-minded. Therefore, he himself is ignorant of the defence of the honor ${ }^{234}$ of Christ. And it is not for the defence of the honor ${ }^{235}$ of Christ that he wishes to abolish "As for those who say," but rather desires to demonstrate to people the art of [his] wisdom. And he is not aware that wisdom never conceals the visible errors and insanity of those, [driven] into the disease of wont.

Twenty-seventh, if a word and a thing is not carried out in peace, behold, the word of Christ fulfils, that "anything more than this comes from evil" (Mat. 5:37), because it

224 A reference to the events related to Ełiazar Aynt'apec'i's actions, claiming that Suk'ias was allegedly following in Ełiazar's footsteps.

225 The Armenian text reads «uhuithp» (sianēt ${ }^{\prime}$ ). See Glossary.

226 The Armenian text reads «nnцq» (araz). See Glossary.

227 The Armenian text reads «pnıppugui» (t'urk'ac'an), here means conversion to Islam.

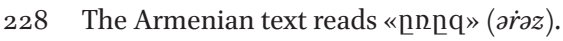

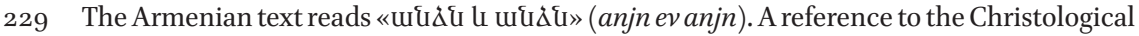
peculiarities of duophysitism.

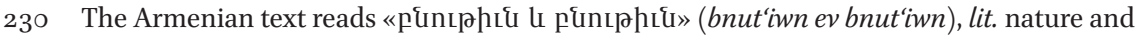

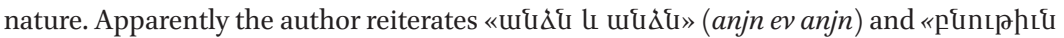
L punıphıц» (bnut'iwn ev bnut'iwn) to accuse Suk'ias of duophysitism.

231 The Armenian text reads «\$hцUi» (filan). See Glossary.

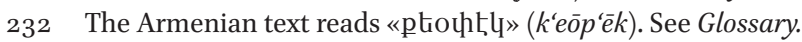

233 The Armenian text reads «luшuши» (xapar). See Glossary.

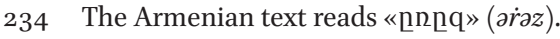

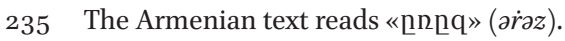


was not for the sake of tranquility of people that it was performed, but for the sake of turmoil. And he thought of the things which he could not affirm, and started to create, but could not complete. And it became ridiculous for beholders, and became a matter of gossip among the beldams. What kind of wisdom is this? Rather foolishness, extreme $^{236}$ [silliness].

Twenty-eighth, foolish is the man, who imagined everyone to be fools, and him alone to be wise. And he has never thought of this, that today he might abolish this [Anathema] and leave, and tomorrow I shall come to church and recite in a loud voice "As for those who say."

Twenty-ninth, during the sermon he praises Ełiazar, and [Suk'ias, this] feeble ${ }^{237}$ pretender, ${ }^{238}$ weeps sobbing, that perhaps he could make some simple-minded ignoramuses weep [too], for in case people are deceived by the art of his imposture, that will become a consolation for his voracious heart. To the very day of his death Ełiazar himself recited "As for those who say." Therefore, this made him [Suk'ias] adversary of his own eulogy, for [it turned out that] the wise one praises the foolish and the worthless one.

Thirtieth, if Ełiazar is justly worthy of his eulogy, then he [Suk'ias] made himself a fool, for he opposed the sage. And his eulogy became deceptive, as he [Suk'ias] made himself adversary to him [Ełiazar], because he [Ełiazar] used to recite "As for those who say."

Thirty-first, in our childhood we heard "As for those who say" sung before great honorable vardapets at the Holy Divine Liturgy for the two Candlemases. ${ }^{239}$

Thirty-second, he became a matter of mockery and outrage, for other Christian nations could say, that this year discovering the ignorance of their own error at the hands of a certain orator and doctor of theology Suk'ias, Armenians eliminated "As for those who say" from the Creed, which they had been reciting up until now. Other Christian nations could say now, that consequently it turned out to be true, that there indeed are many errors among Armenians, which they hide, and some people ignorantly follow

236 The Armenian text reads «jnjd jnjd» (yoyžyoyž) lit. very-very.

237 The Armenian text reads «рһрші» (t'it'al). See Glossary.

238 The Armenian text reads «qunu[u» (zataln). See Glossary.

239 Eremia mentions the Candlemas Liturgies of Theophany or Nativity, and Easter, performed on the vigil of each respective Dominical Feast. In the past, the vigils of all feasts of the Armenian Church were accompanied by the Candlemas Liturgy. Later it was discarded. Eremia's words testify to the discontinuity of this custom in the seventeenth century Ottoman Empire, proving that in his days the Candlemas Liturgies be exceptionally performed on the Vigils of Theophany and Easter. The thirteen-year-old Eremia describes in his Diary the Candlemas Liturgy and Holy Fire he witnessed in Jerusalem during his pilgrimage with his custodian Mahtesi Ambakum and his wife. See K'ēōmiwrčean, Ōagrut'iwn, 309-310. 
them. Behold like nowadays all-wise Suk'ias perceived and abolished "As for those who say."

Thirty-third, they say, that such people are alterable in their will and unsteady in their mind, for who is close to evil, he is swift in assumptions, meaning that while hearing those anathemas, they fear those to be placed upon themselves, thereby they wish to abolish those [anathemas].

Thirty-fourth, alterable is that, when [they wish] to change or override some hymns, or change their order.

Alterable is that, when [they wish] to move the verses of the Psalms and the Sermons backwards and forwards. Alterable is that, when [they command] to say this and not that during the Divine Liturgy, or weather [it should be said] with raised or spread arms, or whether "Glory in the Highest" [should be sung] concordant or voice by voice, or whether with a covered or uncovered head. These all are mutabilities and confusion. Therefore, [being] in delusion of the innovation of the disease of pride he disallows the anathemas, lest they be placed upon him.

Alterable is that nowadays some people say, "How hard is the [observance] of the Armenian fast!" And they lean toward the Greeks [with the words], "Are they not Christians?"

Alterable is that, [when they complain], "How lengthy is the Armenian Service, four-five hours long!" And they tend towards the Franks [by saying], "Are they not Christians?"

Mutability is [when they complain] that the Greeks eat fish on March $25^{t^{240}}$ and on Palm Sunday- "Are not they Christians?"

They turn Frank by saying, "Does not the credibility of Easter belong to them, who possess so many kingdoms and wisdom?" Behold! The mutable plant does not take root! And that kind of mind did not find stability, for it egresses from the Armenians, and does not remain among the Greeks, and is not replanted within the Franks. Thus, the foundation rested on a variable sand and that is [the cause of] its destruction (cf. Luke 6:49).

Thus, it would be suitable to establish this kind of people in peace; it would be proper to pacify the confusion of mistrust of such people; it would be descent to check the words of our forefathers-blessed commenters and interpreters.

240 The Annunciation is celebrated on March 25th in the Greek Orthodox and Catholic Churches, while in the Armenian Church it is solemnized on April 7 th and is accompanied with rigorous fast without fish, meat, and dairy. The Armenian fast is called unnıhug $(a t u h a c)$, literally meaning "salt and bread" that denotes the products allowed during the fast. Great Lent is also called «Unnthughg uwhp» (Atuhac'ic' Pahk'), lit. Lent on salt and bread. The tradition during Eremia's time was to have salt and bread during lent at least once a day. Armenian believers would complain about the rigidity of their lent, compared to the less rigorous rules of the neighboring Greeks and Roman Catholics. 
Thirty-fifth, if someone argues that Ełiazar was hypocritically reciting it for the ears of the people and on his deathbed made his will to this [Suk'ias] not to recite "As for those who say," we give a reply, that he was not in Ejmiacin at the time of Ełiazar's death. And if anyone says that Ełiazar wrote a letter to him on his deathbed concerning this matter, that I do not know. He has to show [us] that letter!

Thirty-sixth, by propagating an innovative thing, he insinuated a thought in the minds of peasants [and] on the tongues of the simple-minded-is it possible, that "As for those who say" was a useless thing, which our people had been reciting out of ignorance?

Thirty-seventh, if those forefathers, who composed it as a tradition for us, were worthless, then he read the writings of the senseless ones, and by these senseless ones, he was affected through their artifice.

Thirty-eight, if they are wise and meritorious so that to be remembered during the Divine Liturgy, to be venerated at their feast days, to read their homilies, to pray for their intercession, then I claim, he does not deserve to take their names on his lips, because he condemns their vow, denigrates their memory, disdains their sayings, demolishes their statues, distorts their writings; that is called a schism, ${ }^{241}$ which will become the cause of complaints and discord, and in the end will lead to turmoil. "Anything more comes from evil" (Mat. 5:37), the troublemaker is a devil!

Thirty-ninth, this [Anathema] is the interpretation, that is to say, the conclusion of the Creed and is the unchangeable testifier [of the Creed], as it confesses [the] Father, [the] Son, and [the] Holy Spirit, coessential and consubstantial. [It] reflects the word and testifies that those who are found external to this, [those] articulating so-and-so, are expelled, dismissed, excommunicated, anathematized by the Holy Church.

Fortieth, Clement, ${ }^{242}$ who slandered upon us so many times, praises our orthodox people in his book as follows: "And following the Creed they confess the nature of God the Word to be unchangeable and immutable against Arius by singing the Nicene anaphora "As for those who say," etc."

Forty-first, the Holy Scripture confirms this thing: as Moses recorded blessings and condemnations in the Law of God and as John the Baptist says, "Whoever believes in the Son has eternal life, but whoever rejects the Son will not see life, for God's wrath remains on them" (John 3:36). And as the Lord commands, "those who have done what is good will rise to live, and those who have done what is evil will rise to be condemned" (John 5:29). And again he commands, "I told you that you would die in your sins; if you do not believe that I am he, you will indeed die in your sins" (John 8:24). And again commands, "For judgment I have come into this world, so that the blind will see and

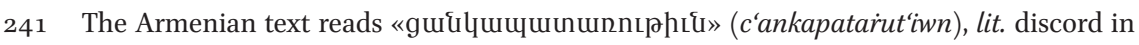
confession.

242 A reference to Clemente Galano. 
those who see will become blind" (John 9:39). And again, "Come, you who are blessed by my Father" (Mat. 25:34), and "Depart from me, you who are cursed, into the eternal fire..." (Mat. 25:41); and there are many other [testimonies] from [the words of] the disciples and veracious of the Holy Scriptures.

This is enough for the auditors; if they read [it] word by word with the intention to be well-informed, and if they comprehend and beware of such people.

Copied in 1793 of the year of [our] Lord and 1242 of the Armenian Era, on March 2, and in $1 Y \cdot V[1207]$ on the first of month Sha'bān, in the orphanage after Saint Patriarch Jacob of Nisibis in Balat.

Glossary of Words in Armeno-Turkish (Funtin hujunun pnıpptintinul)

Uhưulu [axmax]—uð. unhưun, hhưun—arab. ahmak—n., adj. stupid, simpleminded, idiot

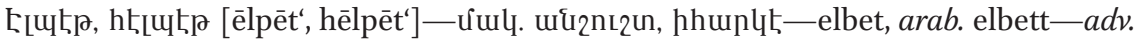
certainly, of course,

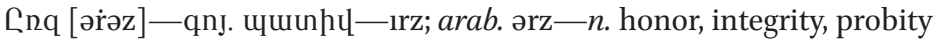

Duhqhq [t'ahgig] — Uul. unnısq, huunuun—trk. tahkik— $n$. investigation, verification (here: $a d v$. definitely, absolutely, for certain)

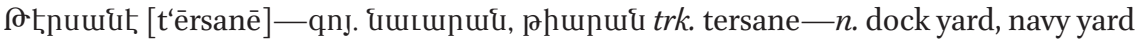
(here: $n$. galleys; penal servitude)

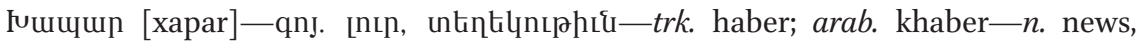
information

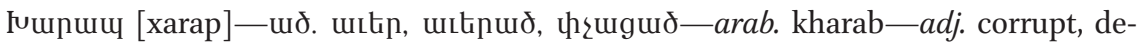
cayed, ruined

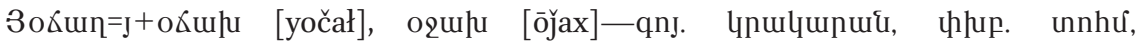
qtinnuuunu - trk. ocak — n. fireplace, fig. $n$. kin, family (here: $n$. child, heir)

Uwhup [sahat'] —qnj. duu —arab. saat—n. hour

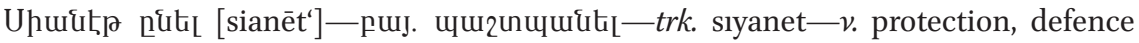
(here: $v$. protect, defend)

ФŁnưưun [p'ēłampar]—qnj. úunqunt_trk. peygamber— $n$. prophet

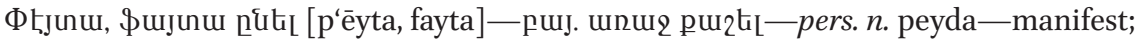
$v$. produce, acquire, beget

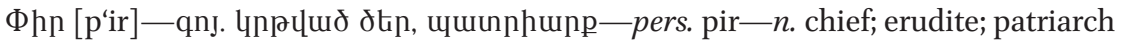

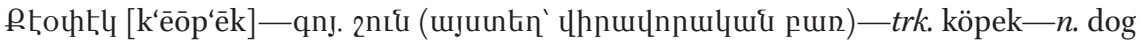
(here: a term of contempt)

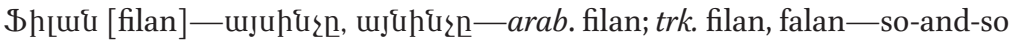


Glossary of Dialectal Forms (Funpunumhi ditin)

U.LLh [alvi]—úul. úh thnpn Ł., uJL lu —adv. a bit more

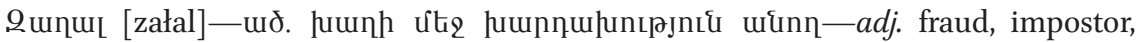
pretender

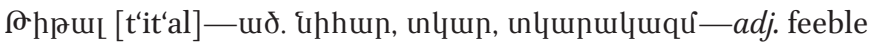

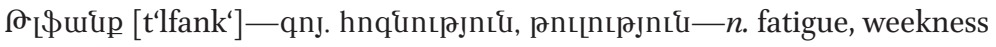

